\title{
Integrated bioinformatics analysis reveals novel key biomarkers and potential candidate small molecule drugs in gestational diabetes mellitus
}

\author{
Basavaraj Vastrad ${ }^{1}$, Chanabasayya Vastrad*2, Anandkumar Tengli ${ }^{3}$ \\ 1. Department of Biochemistry, Basaveshwar College of Pharmacy, Gadag, \\ Karnataka 582103, India.
}

2. Biostatistics and Bioinformatics, Chanabasava Nilaya, Bharthinagar, Dharwad 580001, Karnataka, India.

3. Department of Pharmaceutical Chemistry, JSS College of Pharmacy, Mysuru and JSS Academy of Higher Education \& Research, Mysuru, Karnataka, 570015, India

* Chanabasayya Vastrad

channu.vastrad@gmail.com

Ph: +919480073398

Chanabasava Nilaya, Bharthinagar,

Dharwad 580001 , Karanataka, India 


\section{Abstract}

Gestational diabetes mellitus (GDM) is one of the metabolic diseases during pregnancy. The identification of the central molecular mechanisms liable for the disease pathogenesis might lead to the advancement of new therapeutic options. The current investigation aimed to identify central differentially expressed genes (DEGs) in GDM. The transcription profiling by array data (E-MTAB-6418) was obtained from the ArrayExpress database. The DEGs between GDM samples and non GDM samples were analyzed with limma package. Gene ontology (GO) and REACTOME enrichment analysis were performed using ToppGene. Then we constructed the protein-protein interaction (PPI) network of DEGs by the Search Tool for the Retrieval of Interacting Genes database (STRING) and module analysis was performed. Subsequently, we constructed the miRNA-hub gene network and TF-hub gene regulatory network by the miRNet database and NetworkAnalyst database. The validation of hub genes was performed through receiver operating characteristic curve (ROC). Finally, the candidate small molecules as potential drugs to treat GDM were predicted by using molecular docking. Through transcription profiling by array data, a total of 869 DEGs were detected including 439 up regulated and 430 down regulated genes. Biological process analysis of GO enrichment analysis showed these DEGs were mainly enriched in reproduction, nuclear outer membrane-endoplasmic reticulum membrane network, identical protein binding, cell adhesion, supramolecular complex and signaling receptor binding. Signaling pathway enrichment analysis indicated that these DEGs played a vital in cell surface interactions at the vascular wall and extracellular matrix organization. Ten genes, HSP90AA1, EGFR, RPS13, RBX1, PAK1, FYN, ABL1, SMAD3, STAT3, and PRKCA in the center of the PPI network, modules, miRNA-hub gene regulatory network and TF-hub gene regulatory network were associated with GDM, according to ROC analysis. Finally, the most significant small molecules were predicted based on molecular docking. Our results indicated that HSP90AA1, EGFR, RPS13, RBX1, PAK1, FYN, ABL1, SMAD3, STAT3, and PRKCA could be the potential novel biomarkers for GDM diagnosis, prognosis and the promising therapeutic targets. The current might be essential to understanding the molecular mechanism of GDM initiation and development. 
Keywords: bioinformatics analysis; small drug molecules; differentially expressed genes; gestational diabetes mellitus; novel biomarkers.

\section{Introduction}

Gestational diabetes mellitus (GDM) is the diabetes diagnosed during pregnancy, which affecting $2-5 \%$ of all pregnant women worldwide [1-2]. Risk factors associated with GDM includes obesity, previous occurrence of diabetes, family history of type 2 diabetes, preeclampsia, hypertension, cardiovascular diseases and genetic factors [3]. In GDM blood glucose levels are elevated during the third trimester of pregnancy [4]. Moreover, the elevated glucose level in pregnancy is closely linked with detrimental consequences in the newborn babe, such as fetal hyperglycemia and cardiovascular disease [5]. Therefore, investigating the molecular mechanisms of GDM and early screening of patients with GDM are essential to restrain the occurrence and progression of GDM.

It is therefore essential to find new genes and pathways that are associated with GDM and patient prognosis, which might not only help to explicate the underlying molecular mechanisms associated, but also to discover new diagnostic molecular markers and therapeutic targets. Transcription profiling by array can rapidly detect gene expression on a global basis and are particularly useful in screening for differentially expressed genes (DEGs) [6]. Gene chips allow the analysis of gene expression in a high throughput way with great sensitivity, specificity and repeatability. A symbolic amount of data has been produced via the use of gene chips and the majority of such gene expression data has been uploaded and stored in public databases. Previous investigation concerning GDM transcription profiling by array have found hundreds of DEGs [7-8]. The availability of bioinformatics analysis based on high-throughput technology enabled the investigation of the modification in gene expression and the interaction between differential genes in GDM, to provide novel insights for further in-depth The availability of bioinformatics analysis based on high-throughput technology enabled the investigation of the alterations in mRNA expression and the interaction between differential genes in GDM, to provide novel insights for further in depth GDM investigations. 
In the current investigation, public transcription profiling by array data of EMTAB-6418 from ArrayExpress database was downloaded. A total of 38 GDM samples and 70 non GDM samples data in E-MTAB-6418 were available. DEGs between GDM and non GDM were filtered and obtained using bioconductor package limma in R software. Gene Ontology (GO) and REACTOME pathway enrichment analyses of the DEGs were performed. The functions of the DEGs were further assessed by PPI network and modular analyses to identify the hub genes in GDM. Subsequently, miRNA-hub gene regulatory network and TF-hub gene regulatory network were constructed to identify the target genes, miRNAs and TFs in GDM. Hub genes were validated by receiver operating characteristic curve (ROC). Finally, screening of small drug molecules carried out by using molecular docking. The investigation was designed to obtain deep insights during the pathogenesis of GDM.

\section{Materials and methods}

\section{Transcription profiling by array data information}

The mRNA expression profile E-MTAB-6418 [9] based on A-MEXP-2072 Illumina HumanHT-12_V4_0_R2_15002873_B was downloaded from the ArrayExpress database (https://www.ebi.ac.uk/arrayexpress/) [10], which included 38 GDM samples and 70 non GDM samples.

\section{Identification of DEGs}

To obtain differentially expressed genes (DEGs) between GDM samples and non GDM samples. After limma package in R analysis [11], results including adjusted $\mathrm{P}$ values (adj. P. Val) and $\log \mathrm{FC}$ were provided. Cut-off criterion was set as adj. P. Val $<0.05,|\log \mathrm{FC}|>1.158$ for up regulated genes and $|\log \mathrm{FC}|<-0.83$ for down regulated genes. A list of candidate DEGs was obtained via the above methods.

\section{Gene ontology and pathway enrichment of DEGs analysis}

Gene ontology (GO) analysis (http://geneontology.org/) [12] and REACTOME (https://reactome.org/) [13] pathway enrichment analysis are both integrated in the ToppGene (ToppFun) (https://toppgene.cchmc.org/enrichment.jsp) [14] program. Therefore, ToppGene is capable of providing comprehensive annotations for functional and pathway interpretations. In this experiment, DEGs were uploaded 
onto ToppGene in order to perform related GO and REACTOME pathway enrichment analyses. The cut-off criterion was set as $\mathrm{P}<0.05$.

\section{PPI network establishment and modules selection}

Search Tool for the Retrieval of Interacting Genes StringDB interactome (https://string-db.org/) is a database of known and predicted protein-protein interactions [15]. All candidate DEGs were posted into the STRING website, with a confidence score of $\geq 0.4$ set as the cut-off criterion for PPI network construction. Then, Cytoscape (version 3.8.2, http://www.cytoscape.org/) [16] software was utilized to construct protein interaction relationship network. The Network Analyzer plugin was performed to scale node degree [17], betweenness centrality [18], stress centrality [19] and closeness centrality [20] of the PPI network. Significant modules in the visible PPI network were screened using the PEWCC1 (http://apps.cytoscape.org/apps/PEWCC1) [21] plugin. Degree cut-off=2, node score cut-off $=0.2, \mathrm{k}$-core $=2$, and $\max$ depth $=100$ were set as the cut-off criterion. Three highest-degree modules were extracted, and the potential mechanisms of each module were investigated with ToppGene. A degree of $\geq 10$ was set as the filter criterion. Hub genes with high degree were selected as the potential key genes and biomarkers.

miRNA-hub gene regulatory network construction The miRNet database (https://www.mirnet.ca/) [22] is an open-source platform mainly focusing on miRNA-target interactions. miRNet utilizes fourteen established miRNA-target prediction databases, including TarBase, miRTarBase, miRecords, miRanda, miR2Disease, HMDD, PhenomiR, SM2miR, PharmacomiR, EpimiR, starBase, TransmiR, ADmiRE, and TAM 2.0. In this study, miRNAs were considered the targeted miRNAs of hub genes. Subsequently, the network of the hub genes and their targeted miRNAs was visualized by Cytoscape software.

\section{TF-hub gene regulatory network construction}

The NetworkAnalyst database (https://www.networkanalyst.ca/) [23] is an opensource platform mainly focusing on TF-target interactions. NetworkAnalyst utilizes three established TF-target prediction databases, including ENCODE, JASPAR, ChEA. In this study, TFs were considered the targeted TFs of hub genes based on ChEA database. In this study, TFs were considered the targeted TFs of 
hub genes. Subsequently, the network of the hub genes and their targeted TFs was visualized by Cytoscape software.

\section{Receiver operating characteristic (ROC) curve analysis}

The receiver operating characteristic curve (ROC) was constructed by predicting the probability of a diagnosis being of high or low integrated score of significant hub gene expression in GDM. Area under curve (AUC) analysis was operated to calculate the diagnostic ability by using the statistical package pROC in R software [24].

\section{RT-PCR Analysis}

The HTR-8/SVneo (ATCC CRL3271) cell line procured from ATCC. For normal HTR-8/SVneo (ATCC CRL3271) cell line was grown in RPMI-1640 medium added with $10 \%$ fetal bovine serum, containing $5.5 \mathrm{mM}$ glucose, and $1 \%$ penicillin/streptomycin. Incubate this cell line at $37^{\circ} \mathrm{C}$ in a $5 \% \mathrm{CO} 2$ in humidified cell culture incubator. Similarly, for GDM HTR-8/SVneo (ATCC CRL3271) cell line was grown in RPMI-1640 medium added with $10 \%$ fetal bovine serum, containing $5.5 \mathrm{mM}$ glucose, and $1 \%$ penicillin/streptomycin. Incubate this cell line at $37^{\circ} \mathrm{C}$ in a $5 \% \mathrm{CO} 2$ in humidified cell culture incubator for $24 \mathrm{hrs}$, then stimulated with various concentrations $40 \mathrm{mM}$ of D-glucose for $6 \mathrm{~h}$. TRIzol (cat. no. 9109; Takara Bio, Inc.) was used to isolate total RNA from HTR-8/SVneo cell line and HTR-8/SVneo cell line treated with glucose according to the manufacturer's instructions. TRI Reagent (Sigma, USA).was used to isolate total RNA from each tissue sample according to the manufacturer's instructions. Then, total RNA was reverse transcribed into cDNAs using the FastQuant RT kit (with gDNase; Tiangen Biotech Co., Ltd.). RT-qPCR was performed to measure the levels of cDNAs using a QuantStudio 7 Flex real-time PCR system (Thermo Fisher Scientific, Waltham, MA, USA). RT-PCR procedure was performed as follows: Pre-denaturation at $95^{\circ} \mathrm{C}$ for $30 \mathrm{sec}$ for 1 cycle followed by 40 cycles of $95^{\circ} \mathrm{C}$ for 5 sec and $60^{\circ} \mathrm{C}$ for $20 \mathrm{sec}$. The relative expression level of the hub genes was calculated following comparative CT method [25]. $\beta$-actin was used to normalize the mRNA expression level. The primer sequences are listed in Table 1.

\section{Molecular docking experiments}


Molecular docking was used to find biologically active hits among the designed ligands. Using perpetual software module BIOVIA Discovery Studio (Perpetual), Surflex-Docking docking studies were conducted on active constituents. The lowest binding energy conformation was presumed to form a stable complex within the active site of the over expressed proteins. The $2 \mathrm{D}$ structures were sketched using Chemdraw software, imported and saved into sdf. format using Open Babelfree software. The protein structure was processed after introduction of the protein, the co-crystallized ligand and all the water molecule were excluded from the crystal structure; morehydrogen was added and refined the side chain. This study employed CDOCKER, a grid-based molecular docking approach that utilizes the CHARMm force field. A higher number indicates a stronger bond. The CDOCKER score is expressed as a negative number (-CDOCKER ENERGY).The $\mathrm{H}$-bonds, van der Waals, and electrostatic interactions between the target protein and the ligand were used to measure the CDOCKER energy. The modeled protein's binding site was determined using the template protein's crystal data and proteins in which do not Co-crystallized ligand generated binding site automatically. To make it easier for ligands to interact with amino acids, the binding site sphere center was set at $9 \AA$ radius. Furthermore, using smart minimizer algorithm, CHARMm force field was applied followed by energy minimization to define local minima (lowest energy conformation) of the modeled over expressed proteins with an energy gradient of $0.1 \mathrm{kcal} \mathrm{mol}^{-1} \AA^{-1}$ respectively. The energy minimized receptor protein and the set of 44 natural molecules which was reported as effective in diabetes mellitus and the well-known commonly used allopathic drug Metformin and Glyburide were used as standard and to compare the binding interactions with natural molecules on over expressed proteins in gestational diabetes. The binding site sphere radius set at $X=29.50, Y=-31.38$ and $Z=$ -38.79 were submitted to the CDOCKER parameter and also calculated binding energy. The X-ray co-crystallized structure and were extracted from Protein Data Bank of PDB code of 4UV7, 5NJX,3Q4Z and 3FNI of over expressed genes of Epidermal growth factor receptor (EGFR), Heat shock protein 90 alpha family class A member 1 (HSP90AA1), P21 RAC1 activated kinase 1 (PAK1) and Ringbox 1 (RBX1) respectively in gestational diabetes were selected for docking studies [26 -29]. The best position was inserted into the molecular area between the protein and the ligand. The 2D and 3D interaction of amino acid molecules was achieved using the free online Discovery Studio Visualizer. 


\section{Results}

\section{Identification of DEGs}

Transcription profiling by array data sets was obtained from the ArrayExpress database containing GDM samples and non GDM samples; E-MTAB-6418. Then, the $\mathrm{R}$ package named "limma" was processed for analysis with adjusted $\mathrm{P}<0.05$, $|\log \mathrm{FC}|>1.158$ for up regulated genes and $|\log \mathrm{FC}|<-0.83$ for down regulated genes. All DEGs were displayed in volcano maps (Fig. 1). A total of 869 genes were finally obtained including 439 up regulated genes and 430 down regulated genes in the GDM samples compared to the non GDM samples and are listed Table 1. Top 869 genes in this dataset were displayed in the heatmap (Fig. 2).

\section{Gene ontology and pathway enrichment of DEGs analysis}

To clarify the major functions of these DEGs, we first explored the associated biological processes and REACTOME pathways. The top highly enriched GO terms were divided into three categories: biological process (BP), cellular component (CC), and molecular function (MF) and are listed in Table 2. The most enriched GO terms in BP was reproduction, macromolecule catabolic process, cell adhesion and localization of cell, that in CC was nuclear outer membraneendoplasmic reticulum membrane network, golgi apparatus, supramolecular complex and cell junction, and that in MF were identical protein binding, molecular function regulator, signaling receptor binding and molecular function regulator. In the REACTOME pathway enrichment analysis, the DEGs were mostly enriched in cell surface interactions at the vascular wall, epigenetic regulation of gene expression, extracellular matrix organization and axon guidance and are listed in Table 3.

\section{PPI network establishment and modules selection}

By using the STRING database, the PPI network of DEGs was established and consisted of 4687 nodes and 11236 edges (Fig.3). A total of 10 hub genes were selected for key biomarker identification and are listed in Table 3. They consisted of 5 up regulated genes (HSP90AA1, EGFR, RPS13, RBX1 and PAK1) and 5 down regulated genes (FYN, ABL1, SMAD3, STAT3 and PRKCA). Then PEWCC1 was used to find clusters in the network. Four modules were calculated 
according to $\mathrm{k}$-core $\square=\square 2$. Among them, module 1 contained 16 nodes and 32 edges, with the highest score (Fig.4A) and module 2 contained 16 nodes and 34 edges (Fig.4B). We performed the functional analysis for the top 2 modules. In functional enrichment analysis, the DEGs of module 1 were mostly enriched in post-translational protein modification, developmental biology and macromolecule catabolic process; the DEGs of module 2 in supramolecular complex and localization of cell.

\section{miRNA-hub gene regulatory network construction}

miRNet database was applied to screen the targeted miRNAs of the hub genes. Cytoscape software was used to construct the miRNA-hub gene network. As illustrated in Fig. 5, the interaction network consists of 307 hub genes and 2280 miRNAs. According to the hub genes and miRNAs in the network ranked by their degree of connectivity using Network Analyzer and are listed in Table 4. Based on the expression trend of hub genes in GDM, we found that UBE2D3 was the predicted target of hsa-mir-6127, HSP90AA1 was the predicted target of hsa-let$7 \mathrm{~d}-5 \mathrm{p}$, PAK2 was the predicted target of hsa-mir-8063, DDB1 was the predicted target of hsa-mir-329-3p, DVL3 was the predicted target of hsa-mir-1207-5p, FYN was the predicted target of hsa-mir-4651, ABL1 was the predicted target of hsamir-410-5p, SMAD3 was the predicted target of hsa-mir-222-3p, STAT3 was the predicted target of hsa-mir-29c-3p and PRKCA was the predicted target of hsamir-663a.

\section{TF-hub gene regulatory network construction}

NetworkAnalyst database was applied to screen the targeted TFs of the hub genes. Cytoscape software was used to construct the TF-hub gene network. As illustrated in Fig. 6, the interaction network consists of 306 hub genes and 195 TFs. According to the hub genes and TFs in the network ranked by their degree of connectivity using Network Analyzer and are listed in Table 4. Based on the expression trend of hub genes in GDM, we found that HSP90AA1 was the predicted target of E2F1, UBE2D3 was the predicted target of HCFC1, EGFR was the predicted target of SRY, PSMC4 was the predicted target of ZFX, DDB1 was the predicted target of RUNX1, STAT3 was the predicted target of SPI1, CCND1 was the predicted target of MYBL2, SMAD3 was the predicted target of SUZ12, 
FOXO1 was the predicted target of TBX3 and PRKCA was the predicted target of YAP1.

\section{Receiver operating characteristic (ROC) curve analysis}

ROC curve analysis was implemented to evaluate the capacity of hub genes to distinguish GDM and non GDM in E-MTAB-6418, HSP90AA1, EGFR, RPS13, RBX1, PAK1, FYN, ABL1, SMAD3, STAT3 and PRKCA, exhibiting better diagnostic efficiency for GDM and non GDM, and the combined diagnosis of these ten hub genes was more effective. The AUC index for the 10 hub gene scores were $0.906,0.838,0.825,0.897,0.863,0.876,0.855,0.880,0.932$ and 0.872 , and are shown Fig. 7.

\section{RT-PCR Analysis}

To further verify the expression level of hub genes in GDM, RT-PCR was performed to calculate the mRNA levels of the ten hub genes identified in the present study (HSP90AA1, EGFR, RPS13, RBX1, PAK1, FYN, ABL1, SMAD3, STAT3 and PRKCA) in GDM. As illustrated in Fig. 8, the expression of HSP90AA1, EGFR, RPS13, RBX1, PAK1 were significantly up regulated in GDM samples compared with normal, while FYN, ABL1, SMAD3, STAT3 and PRKCA were significantly down regulated in GDM samples compared with normal. The present RT- PCR results were in line with the aforementioned bioinformatics analysis, suggesting that these hub genes might be linked to the molecular mechanism underlying GDM.

\section{Molecular docking experiments}

In the recent findings, the docking study was performed using Biovia Discovery Studio perpetual software to analyse the binding pattern of the natural plants products such as herbs have the ability to lower blood glucose levels and ameliorate diabetes with decreased adverse side effects. The natural well known phytoconstituents which decreases the blood sugar level are Malvidin 3laminaribioside (MLR), Ferulic acid (FRA), Inosporone (INO), Allicin (ALL), Liriodenin (LIR), Azadirachitin (AZA), Sulforaphane, Cajanin (CAJ), Carvone (CAR), Capsaicin (CAP), Terpineol (TER), Phellandrene (PHE), Terpene (TPN), Ellagic acid (ELA), Leucodelphinidin, O-methyltylophorinidine (OMT), 
Gymnemic acid, beta-Carotene (BCR), Leucocyanidin (LEC), Syringin (SYR), Ginsenoside (GNS), Phyllanthin (PHY), Punicalagin (PUC), Punicalin (PUN), Arjunic acid (AJA), Arjunetin (ARJ), Arabic acid (ARA), Arjungenin (ARG), Gingerol (GIN), Shogaol, Aloe emodin (ALE), Arabic acid (ARA), Aloin (ALO), Charantin (CHR), Cinnamic acid (CIN), Curcumin (CUR), Euginol (EUG), Gymnemagenin (GMG), Gymnestrogenin (GYM), Hydroxylucin (HYD), Methoxy hydroxyl chalcoli (MHC), Myricetin (MYR), Nimbine (NIM), Quercetin (QUE), Vicine (VIC) and Shagoal (SHA) are shown in Fig. 9. The molecules were constructed based on the natural plant products containing these chemical constituents which play vital role in reducing type 2 diabetes mellitus. The traditional plant products are used in conjunction with allopathic drug to reduce the dose of the allopathic drugs and or to increase the efficacy of allopathic drugs. Some common and most prominent antidiabetic plants and active principles were selected from their phytochemicals for docking studies in the present research to identify the active natural molecule to avoid the use of allopathic drugs in gestational diabetes and the blood sugar level is controlled by altering the diet. For docking experiments well known and most commonly used two allopathic drugs such as Glyburide (GLY), Metformin (MET) in gestational diabetes are used as standard and to compare the binding interaction of natural phyto constituents with allopathic drugs. A total of common 44 in that 42 natural active constituents few from each of flavonoids, saponins, tannins and glycosides etc., present in plant extracts responsible for antidiabetic function and 2 allopathic drugs were chosen for docking studies on over expressed proteins and the structures are depicted in figure 1 respectively. The one protein from each over expressed genes in gestational diabetes 2 diabetes mellitus such as EGFR (epidermal growth factor receptor), HSP90AA1 (heat shock protein 90 alpha family class A member 1), PAK1 (p21 (RAC1) activated kinase 1), and RBX1 (ring-box 1) and their X-RAY crystallographic structure and co-crystallized PDB code and their PDB code of 4UV7, 5NJX, 3Q4Z and 3FNI respectively were constructed for docking. The docking on natural active constituents was conducted to classify the potential molecule and their binding affinity to proteins. A higher number of negative number -CDOCKER energy and binding energy indicates a stronger binding interactions with proteins, few constituents obtained with a greater -CDOCKER energy and binding energy respectively with particular proteins. Docking experiments were carried out on a total of 42 constituents from plant products, few 
constituents obtained excellent -CDOCKER energy and binding energy. Out of 44 molecules few of the molecules obtained -CDOCKER interaction energy of more than 40 and majority with more than 30 and less than 40, few molecules obtained optimum -CDOCKER interaction energy of less than 30 respectively. the molecules with -CDOCKER interaction energy of 40 and above are said to have good interaction with proteins and stable. The natural constituents of the molecules GLY, GNS, GYM, MLR, PUC and ALO, GLY, MLRand ALE, ALO, BCR, CAP, CHR, ELA, LUR, GIN, GLY, GMG, GNS, GYM, LEC, LIR, MLR, MYR, NIM, OMP, PHY, PUC, PUN, QUE, SHE,VI C obtained a -CDOCKER interaction energy of more than 40 with protein of PDB code 5NJX and 3FNI and 3Q4Z respectively. The natural constituents obtained -CDOCKER interaction energy of less than 40 and more than 30 are ALO, ARJ, BCR, CHR, CUR, PHY, PUN and BCR, CAJ, CAP, CUR, GIN, LEC, MYR, OMP, QUE, VIC and AJA, ARA, ARG, CAJ, FRA, HYD, MHC and GNS, PHY, PUC, PUN with 5NJX and 3FNI and 3Q4Z and 4UV7. The constituents obtained less than 30 and more than 20 are AJA, ALE, ARG, CAJ, CAP, GIN, GMG, GYM, HYD, LEC, MHC, MLR, MYR, NIM, OMP, QUE, VIC and AJA, ALE, ALL, ARG, AJA,CHR, CIN, EUG, FRA, GMG, GNS, GYM, LIR, MHC, NIM, PUC and ALL, CIN, EUG, MET, TER and ALA, ALE, ALO, ARJ, BCR, CAJ, CHR, ELA, FRA, GIN, GMG, LEC, MLR, MYR, OMP, QUE, SHA with 5NJX and 3FNI and 3Q4Z and 4UV7. Following the molecules obtained less than 20 -CDOCKER interaction energy are ALL, ARA, CAR, CHR, CIN, EUG, FRA, LIR, MET, PHE, TER, TPN and ARJ, ARA, CAR, HYD, MET, PHE, TPN and CAR, PHE, TPN and AJA, ALL, ARG, CAR, CIN, EUG, GYM, HYD, LIR, MET, MHC, NIM, PHE, TER, TPN, VIC with protein $5 \mathrm{NJX}$ and $3 \mathrm{FNI}$ and 3Q4Z and 4UV7 respectively the biding energy,-CDOCKER energy and -CDOCKER interaction energy are depicted in Table 7. The two molecules such as ALO and MAL Fig. 10 and Fig. 11, their interaction with amino acids of proteins with 3D strictures for 3FN1 Fig.12 and 3Q4Z Fig.13, while 2D strictures for 3FN1 Fig.14 and 3Q4Z Fig.15.

\section{Discussion}

Although people have continuously investigated GDM, the early diagnosis and treatment of GDM is still a huge problem due to the inadequacy of understanding of the molecular mechanisms that drive the occurrence and progression of GDM. 
Therefore, in-depth investigation into the factors and mechanisms of GDM advancement are necessary for GDM diagnosis and treatment. Due to welldeveloped transcription profiling by array technology, it is accessible to resolve the general genetic modification in the development of diseases, which can allow for the recognition of gene targets for diagnosis, therapy, and prognosis of GDM.

In our study, a total of 869 DEGs were screened, including 439 up regulated genes and 430 down regulated genes. Several studies have reported that expression of CGB5 was essential for pregnancy success [30]. Aberrations of CRH (corticotropin releasing hormone) [31] and PSG1 [32] contribute to preeclampsia occurrence. The expression of CYP19A1 was significantly up regulated in hypertensive disorders of pregnancy [33]. Based on previous studies, CD248 is generally associated with progression of hypertension [34], but this gene might be linked with development of GDM. Lin et al [35] reported that expression of COL1A1 was essential for type 2 diabetes mellitus progression, but this gene might be involved in the development of GDM. Delfín et al [36] found that $\mathrm{ABI} 3 \mathrm{BP}$ was responsible for progression of cardiovascular diseases, but this gene might be linked with development of GDM. MFAP4 was reported to cause type 1diabetes mellitus [37], but this gene might be responsible for progression of GDM.

DEGs were found to be enriched in reproduction, nuclear outer membraneendoplasmic reticulum membrane network, identical protein binding, cell surface interactions at the vascular wall, cell adhesion, supramolecular complex, signaling receptor binding and extracellular matrix organization. CEBPB (CCAAT enhancer binding protein beta) [38], ACSL4 [39], MBD2 [40], ULK1 [41], NUCB2 [42], TWIST1 [43], HOOK2 [44], CLDN7 [45], TBK1 [46], YIPF6 [47], TFRC (transferrin receptor) [48], ENPP2 [49], SLIT2 [50], MFGE8 [51], FAT1 [52], GPC4 [53], COL6A3 [54], EGFL6 [55], AOC3 [56], CCN2 [57], LYVE1 [58], RARA (retinoic acid receptor alpha) [59], COL18A1 [60], THY1 [61], CD36 [62], PEMT (phosphatidylethanolamine N-methyltransferase) [63], AIF1L [64], OXTR (oxytocin receptor) [65], LMNA (lamin A/C) [66], CXCL14 [67], DKK3 [68], ANGPTL2 [69] and CMTM7 [70] were reported to be associated with obesity, but these genes might be linked with progression of GDM. AHR (aryl hydrocarbon receptor) [71], STS (steroid sulfatase) [72], PLAC1 [73], CYP11A1 [74], PSG11 [75], STAT5B [76], TLR3 [77], FOLR1 [78], HSPB1 [79], 
HSP90AA1 [80], ANXA4 [81], ATF3 [82], DAPK1 [83], ENTPD1 [84], ABL1 [85], VSIG4 [86], CD99 [87], VWF (von Willebrand factor) [88], PODXL (podocalyxin like) [89], PDPN (podoplanin) [90], RND3 [91], VCAN (versican) [92], AXL (AXL receptor tyrosine kinase) [93], PIEZO1 [94], GAS6 [93], LAMA4 [95], CAV1 [96], DLL1 [97], CD44 [98], CD81 [99], SMAD3 [100], NES (nestin) [101], DCN (decorin) [102], AGTR1 [103], SLIT3 [104], B2M [105], STAT3 [106], STC1 [107] and ADAMTS1 [108] were shown to participate in facilitating the preeclampsia. Majchrzak-Celińska et al [109] and Shimodaira et al [110] reported that HSD11B2 and HSD3B1 are responsible for hypertensive disorders of pregnancy. Altered expression of CSNK2A2 [111], NFE2 [112], CAMK2G [113], RASGRP1 [114], S100P [115], SRR (serine racemase) [116], DHPS (deoxyhypusine synthase) [117], DYRK1A [118], JAG1 [119], COL3A1 [120], VTN (vitronectin) [121], WNT3A [122], ACTA2 [123], SEMA3A [124], RARRES2 [125], CAV2 [126] and SPRED1 [127] were observed to be associated with the progression of type 2 diabetes mellitus, but these genes might be liable for advancement of GDM. In a previous report, Santiago et al [128], Auburger et al [129], Qu et al [130], Śnit et al [131] and Hjortebjerg et al [132] reported that SLC22A5, SH2B3, ITPR3, CALD1 and IGFBP4 expression might be regarded as an indicator of susceptibility to type 1 diabetes mellitus, but these genes might be associated with progression of GDM. Krishnan et al [133], Hu et al [134], Martins et al [135], Prieto-Sánchez et al [136], Sugulle et al [137], Zhao et al [138], Siddiqui et al [139], Han et al [140], Lappas et al [141], Wang et al [142], ArtuncUlkumen et al [143], Blois et al [144], Vacínová et al [145] and Vilmi-Kerälä et al [146] demonstrated that the expression of CREBRF (CREB3 regulatory factor), STRA6, EGFR (epidermal growth factor receptor), MFSD2A, GDF15, PAK1, VCAM1, IGFBP2, IGFBP7, PRKCA (protein kinase $\mathrm{C}$ alpha), ADAMTS9, LGALS1, BIN1, TIMP1 and are associated with progression of GDM. Aquila et al, [147], Chen et al. [148], Xie et al. [149], Zhang et al. [150], Aspit et al. [151], Akadam-Teker et al. [152], Jiang et al. [153], Cetinkaya et al. [154], GrondGinsbach et al [155], Dong et al. [156], Chardon et al. [157], Chen et al. [158], Yamada et al. [159], Hu et al. [160], Bobik and Kalinina [161], Schwanekamp et al. [162], Liu et al. [163], Schroer et al. [164], Raza et al. [165], Yang et al. [166], Azuaje et al. [167], Durbin et al. [168], Chowdhury et al. [169], Wang et al. [170], Li et al. [171], Lv et al. [172], Bertoli-Avella et al. [173], Grossman et al. [174], Andenæs et al. [175] and Chen et al. [176] demonstrated that HES1, SPIN1, 
TBX3, EVA1A, CAP2, BMP1, HSPB8, RDX (radixin), COL5A1, LIMS2, PARVA (parvin alpha), EGFLAM (EGF like, fibronectin type III and laminin G domains), NEXN (nexilin F-actin binding protein), TNFRSF14, TGFBI (transforming growth factor beta induced), HAVCR2, CDH11, COL4A1, COL4A2, COL5A2, SHROOM3, HYAL2, PDLIM3, ETS2, PLSCR4, TGFB3, COL6A2 and LTBP2 could induce cardiovascular diseases, but these genes might be essential for progression of GDM. Flamant et al [177], Wan et al [178], Zhang et al [179], Vallvé et al [180], Heximer and Husain [181], Selvarajah et al [182], Jain et al [183], Sun et al [184], Satomi-Kobayashi et al [185], Jiang et al [186], Waghulde et al [187] and Dahal et al [188] reported that DDR1, CAST (calpastatin), KYNU (kynureninase), FBLN2, SPON1, VEGFC (vascular endothelial growth factor C), FLNA (filamin A), SNAI2, MYADM (myeloid associated differentiation marker), NECTIN2 and SMTN (smoothelin), GPER1, PDGFRB (platelet derived growth factor receptor beta) crucially contribute to the development of hypertension, but these genes might be linked with advancement of GDM.

From the PPI network and modules diagram, it can be observed that HSP90AA1, EGFR, RPS13, RBX1, PAK1, FYN (FYN proto-oncogene, Src family tyrosine kinase), ABL1, SMAD3, STAT3, PRKCA, UBE2A, UCHL3, TUBB2A, ACTA2 and TBCB (tubulin folding cofactor B) were the key nodes of the PPI network and modules, with the highest node degree, betweenness, stress and closeness value. RPS13, RBX1, FYN, UBE2A, TUBB2A and TBCB were the novel biomarkers for the progression of GDM.

From the miRNA-hub gene network construction and TF-hub gene network diagram, it can be observed that UBE2D3, HSP90AA1, PAK2, DDB1, DVL3, FYN, ABL1, SMAD3, STAT3, PRKCA, EGFR, PSMC4, CCND1, FOXO1, hsamir-6127, hsa-let-7d-5p, hsa-mir-8063, hsa-mir-329-3p, hsa-mir-1207-5p, hsa-mir4651, hsa-mir-410-5p, hsa-mir-222-3p, hsa-mir-29c-3p, hsa-mir-663a, E2F1, HCFC1, SRY, ZFX, RUNX1, SPI, MYBL2, SUZ12, TBX3 and YAP1 were the key nodes of the miRNA-hub gene network construction and TF-hub gene network, with the highest node degree value. Expression of the CCND1 gene plays a role in the development of obesity [189], but this gene might be associated with progression of GDM. FOXO1 [190], hsa-mir-1207-5p [191], hsa-mir-4651 [191], hsa-mir-222-3p [192] and E2F1 [193] are essential for the progression of GDM. 
Hsa-let-7d-5p [194], hsa-mir-29c-3p [195] and SRY (Sex-determining Region Y) [196] have been shown to have an important role in type 2 diabetes mellitus, but these genes might be responsible for progression of GDM. Hsa-mir-663a [197] and TBX3 [198] have been shown as a promising biomarker in cardiovascular diseases, but this gene might be involved in progression of GDM. RUNX1 [199] and YAP1 [200] have been demonstrated to function in preeclampsia. UBE2D3, PAK2, DDB1, DVL3, PSMC4, hsa-mir-6127, hsa-mir-8063, hsa-mir-329-3p, hsamir-410-5p, HCFC1, ZFX (zinc finger protein, X-linked), SPI1, MYBL2 and SUZ12 were the novel biomarkers for the progression of GDM.

The molecule GLY, MLR obtained a good -CDOCKER interaction energy with 5NJX, 3FNI and 3Q4Z the -CDOCKER interaction energy of GLY is 41.37, 59.92, 41.44 and for MLR is 40.68, 87.65, 43.47 with 5NJX, 3FNI and 3Q4Z respectively. The two molecules such as ALO and MAL its interaction with amino acids are 2' hydroxyl group formed hydrogen bond interaction with ASP-89 and 3', 4' hydroxyl groups formed hydrogen bond interaction with GLU-86. Following 6' hydroxyl group formed hydrogen bond interaction with LYS-61. The C-13 hydroxyl formed hydrogen bond interaction with ASP-389 and ring C electrons formed pi-pi t-shaped interactions with HIS-63 and pi-alkyl interaction with LYS388. Ring A electrons formed pi-carbon interaction with LYS-388 and LYS61 respectively. The ring C electrons and 4' hydroxyl group of molecule MLR formed sulphur oxygen interaction with MET-344 and ring $\mathrm{C}$ electrons formed pi-alkyl interaction with LEU-396. The ring A 5 \& 6 hydroxyl group formed hydrogen bond interaction with ASP-354 \& LYS-538. Ring D 3" \& 6" hydroxyl group formed hydrogen bond interaction with ASP-393 \& GLY-277, 3' hydroxyl group formed pi-alkyl interaction with $\mathrm{Mg}$ ion. Ring $\mathrm{D}$ 5'hydroxyl group formed hydrogen bond interaction with ARG-299. Ring E 6" ' alkyl hydroxyl formed Carbon hydrogen interaction with LYS-391 and ring E oxygen, 3"' hydroxyl group and 6", alkyl hydroxyl formed pi-alkyl interaction with $\mathrm{Mg}$ ions respectively.

In conclusion, the results from the current investigation not only identify a series of DEGs, but also analyze the significant modules, hub and target genes identification, and screening of small therapeutic molecules. In addition, in order to further verify the bioinformatics analysis data, the current investigation detected the expression levels of hub genes (HSP90AA1, EGFR, RPS13, RBX1, PAK1, 
FYN, ABL1, SMAD3, STAT3 and PRKCA) in a GDM. These hub genes might serve as potential diagnostic and prognostic biomarkers, and novel therapeutic targets in GDM.

\section{Acknowledgement}

I thank Marian C Aldhous, Tommy's Centre for Fetal and Maternal Health, Medical Research Council Centre for Reproductive Health, Queen's Medical Research Institute, University of Edinburgh, Edinburgh, UK, very much, the author who deposited their profiling by high throughput sequencing dataset E-MTAB6418, into the public ArrayExpress database.

\section{Conflict of interest}

The authors declare that they have no conflict of interest.

\section{Ethical approval}

This article does not contain any studies with human participants or animals performed by any of the authors.

\section{Informed consent}

No informed consent because this study does not contain human or animals participants.

\section{Availability of data and materials}

The datasets supporting the conclusions of this article are available in the ArrayExpress database (https://www.ebi.ac.uk/arrayexpress/) repository. [(EMTAB-6418) (https://www.ebi.ac.uk/arrayexpress/experiments/E-MTAB6418/?array=A-MEXP-2072]

\section{Consent for publication}

Not applicable.

\section{Competing interests}

The authors declare that they have no competing interests.

\section{Author Contributions}


B. V - Writing original draft, and review and editing

C. V - Software and investigation

A. T - Formal analysis and validation

\section{Authors}

Basavaraj Vastrad

Anandkumar Tengli

Chanabasayya Vastrad
ORCID ID: $\underline{0000-0003-2202-7637}$

ORCID ID: 0000-0001-8076-928X

ORCID ID: $\underline{0000-0003-3615-4450}$

\section{References}

1. Alfadhli EM. Gestational diabetes mellitus. Saudi Med J. 2015;36(4):399406. doi:10.15537/smj.2015.4.10307

2. Lambrinoudaki I, Vlachou SA, Creatsas G. Genetics in gestational diabetes mellitus: association with incidence, severity, pregnancy outcome and response to treatment. Curr Diabetes Rev. 2010;6(6):393-399. doi:10.2174/157339910793499155

3. Chen P, Wang S, Ji J, Ge A, Chen C, Zhu Y, Xie N, Wang Y. Risk factors and management of gestational diabetes. Cell Biochem Biophys. 2015;71(2):689-694. doi:10.1007/s12013-014-0248-2

4. Tieu J, McPhee AJ, Crowther CA, Middleton P, Shepherd E. Screening for gestational diabetes mellitus based on different risk profiles and settings for improving maternal and infant health. Cochrane Database Syst Rev. 2017;8(8):CD007222. doi:10.1002/14651858.CD007222.pub4

5. Farrar D, Simmonds M, Bryant M, Sheldon TA, Tuffnell D, Golder S, Dunne F, Lawlor DA. Hyperglycaemia and risk of adverse perinatal outcomes: systematic review and meta-analysis. BMJ. 2016;354:i4694. doi:10.1136/bmj.i4694

6. Zhu N, Hou J, Wu Y, Li G, Liu J, Ma G, Chen B, Song Y.Identification of key genes in rheumatoid arthritis and osteoarthritis based on bioinformatics analysis. Medicine (Baltimore). 2018;97(22):e10997. doi:10.1097/MD.0000000000010997 
7. Liu Y, Wang Y, Wang Y, Lv Y, Zhang Y, Wang H. Gene expression changes in arterial and venous endothelial cells exposed to gestational diabetes mellitus. Gynecol Endocrinol. 2020;36(9):791-795. doi:10.1080/09513590.2020.1712696

8. Zhang Q, He M, Wang J, Liu S, Cheng H, Cheng Y. Predicting of disease genes for gestational diabetes mellitus based on network and functional consistency. Eur J Obstet Gynecol Reprod Biol. 2015;186:91-96. doi:10.1016/j.ejogrb.2014.12.016

9. Chiswick CA, Reynolds RM, Denison FC, Drake AJ, Forbes S, Newby DE, Walker BR, Quenby S, Wray S, Weeks A, et al. Does metformin reduce excess birthweight in offspring of obese pregnant women? A randomised controlled trial of efficacy, exploration of mechanisms and evaluation of other pregnancy complications. Southampton (UK): NIHR Journals Library; August 2016.

10. Kolesnikov N, Hastings E, Keays M, Melnichuk O, Tang YA, Williams E, Dylag M, Kurbatova N, Brandizi M, Burdett T, et al. ArrayExpress update-simplifying data submissions. Nucleic Acids Res. 2015;43(Database issue):D1113-D1116. doi:10.1093/nar/gku1057

11. Ritchie ME, Phipson B, Wu D, Hu Y, Law CW, Shi W, Smyth GK. limma powers differential expression analyses for RNA-sequencing and microarray studies. Nucleic Acids Res. 2015;43(7):e47. doi:10.1093/nar/gkv007

12.Thomas PD. The Gene Ontology and the Meaning of Biological Function. Methods Mol Biol. 2017;1446:15 $\square 24$. doi:10.1007/978-1-4939-3743-1_2

13.Fabregat A, Jupe S, Matthews L, Sidiropoulos K, Gillespie M, Garapati P, Haw R, Jassal B, Korninger F, May B et al The Reactome Pathway Knowledgebase. Nucleic Acids Res. 2018;46(D1):D649-D655. doi:10.1093/nar/gkx1132

14. Chen J, Bardes EE, Aronow BJ, Jegga AG. ToppGene Suite for gene list enrichment analysis and candidate gene prioritization. Nucleic Acids Res. 2009;37(Web Server issue):W305-W311. doi:10.1093/nar/gkp427

15.Szklarczyk D, Morris JH, Cook H, Kuhn M, Wyder S, Simonovic M, Santos A, Doncheva NT, Roth A, Bork P, et al. The STRING database in 2017: quality-controlled protein-protein association networks, made broadly accessible. Nucleic Acids Res. 2017;45(D1):D362-D368. doi:10.1093/nar/gkw937 
16. Shannon P, Markiel A, Ozier O, Baliga NS, Wang JT, Ramage D, Amin N, Schwikowski B, Ideker T Cytoscape: a software environment for integrated models of biomolecular interaction networks. Genome Res 2003;13(11):2498-2504. doi:10.1101/gr.1239303

17.Przulj N, Wigle DA, Jurisica I. Functional topology in a network of protein interactions. Bioinformatics. 2004;20(3):340-348. doi:10.1093/bioinformatics/btg415

18.Nguyen TP, Liu WC, Jordán F. Inferring pleiotropy by network analysis: linked diseases in the human PPI network. BMC Syst Biol. 2011;5:179. doi:10.1186/1752-0509-5-179

19. Shi Z, Zhang B. Fast network centrality analysis using GPUs. BMC Bioinformatics. 2011;12:149. doi:10.1186/1471-2105-12-149

20.Fadhal E, Gamieldien J, Mwambene EC. Protein interaction networks as metric spaces: a novel perspective on distribution of hubs. BMC Syst Biol. 2014;8:6. doi:10.1186/1752-0509-8-6

21.Zaki N, Efimov D, Berengueres J. Protein complex detection using interaction reliability assessment and weighted clustering coefficient. BMC Bioinformatics. 2013;14:163. doi:10.1186/1471-2105-14

22.Fan Y, Xia J (2018) miRNet-Functional Analysis and Visual Exploration of miRNA-Target Interactions in a Network Context. Methods Mol Biol 1819:215-233. doi:10.1007/978-1-4939-8618-7_10

23.Zhou G, Soufan O, Ewald J, Hancock REW, Basu N, Xia J (2019) NetworkAnalyst 3.0: a visual analytics platform for comprehensive gene expression profiling and meta-analysis. Nucleic Acids Res 47:W234-W241. doi:10.1093/nar/gkz240

24. Robin X, Turck N, Hainard A, Tiberti N, Lisacek F, Sanchez JC, Müller M. pROC: an open-source package for $\mathrm{R}$ and $\mathrm{S}+$ to analyze and compare ROC curves. BMC Bioinformatics 2011;12:77. doi:10.1186/1471-2105-12-77

25.Livak KJ, Schmittgen TD Analysis of relative gene expression data using real-time quantitative PCR and the 2(-Delta Delta C(T)) Method. Methods 2001;25:402-408. doi:10.1006/meth.2001.1262

26.Wierzchowski M, Dutkiewicz Z, Gielara-Korzańska A, Korzański A, Teubert A, Teżyk A, Stefański T, Baer-Dubowska W, Mikstacka R. Synthesis, biological evaluation and docking studies of trans-stilbene 
methylthio derivatives as cytochromes P450 family 1 inhibitors. Chem Biol Drug Des. 2017;90(6):1226-1236. doi:10.1111/cbdd.13042

27.O'Boyle NM, Banck M, James CA, Morley C, Vandermeersch T, Hutchison GR. Open Babel: An open chemical toolbox. J Cheminform. 2011;3:33. doi:10.1186/1758-2946-3-33

28.Petchi RR, Vijaya C, Parasuraman S. Antidiabetic activity of polyherbal formulation in streptozotocin - nicotinamide induced diabetic wistar rats. J Tradit Complement Med. 2014;4(2):108-117. doi:10.4103/22254110.126174

29.Gupta RC, Chang D, Nammi S, Bensoussan A, Bilinski K, Roufogalis BD. Interactions between antidiabetic drugs and herbs: an overview of mechanisms of action and clinical implications. Diabetol Metab Syndr. 2017;9:59. doi:10.1186/s13098-017-0254-9

30.Uusküla L, Rull K, Nagirnaja L, Laan M. Methylation allelic polymorphism (MAP) in chorionic gonadotropin beta5 (CGB5) and its association with pregnancy success. J Clin Endocrinol Metab. 2011;96(1):E199-E207. doi:10.1210/jc.2010-1647

31.Purwosunu Y, Sekizawa A, Farina A, Wibowo N, Okazaki S, Nakamura M, Samura O, Fujito N, Okai T.Cell-free mRNA concentrations of $\mathrm{CRH}$, PLAC1, and selectin-P are increased in the plasma of pregnant women with preeclampsia. Prenat Diagn. 2007;27(8):772-777. doi:10.1002/pd.1780

32.Temur M, Serpim G, Tuzluoğlu S, Taşgöz FN, Şahin E, Üstünyurt E. Comparison of serum human pregnancy-specific beta-1-glycoprotein 1 levels in pregnant women with or without preeclampsia. J Obstet Gynaecol. 2020;40(8):1074-1078. doi:10.1080/01443615.2019.1679734

33.Shimodaira M, Nakayama T, Sato I, Sato N, Izawa N, Mizutani Y, Furuya K, Yamamoto T. Estrogen synthesis genes CYP19A1, HSD3B1, and HSD3B2 in hypertensive disorders of pregnancy. Endocrine. 2012;42(3):700-707. doi:10.1007/s12020-012-9699-7

34.Xu T, Shao L, Wang A, Liang R, Lin Y, Wang G, Zhao Y, Hu J, Liu S. CD248 as a novel therapeutic target in pulmonary arterial hypertension. Clin Transl Med. 2020;10(5):e175. doi:10.1002/ctm2.175

35.Lin G, Wan X, Liu D, Wen Y, Yang C, Zhao C. COL1A1 as a potential new biomarker and therapeutic target for type 2 diabetes. Pharmacol Res. 2021;105436. doi:10.1016/j.phrs.2021.105436 
36.Delfín DA, DeAguero JL, McKown EN. The Extracellular Matrix Protein ABI3BP in Cardiovascular Health and Disease. Front Cardiovasc Med. 2019;6:23. doi:10.3389/fcvm.2019.00023

37.Blindbæk SL, Schlosser A, Green A, Holmskov U, Sorensen GL, Grauslund J. Association between microfibrillar-associated protein 4 (MFAP4) and micro- and macrovascular complications in long-term type 1 diabetes mellitus. Acta Diabetol. 2017;54(4):367-372 . doi:10.1007/s00592-016-0953$\mathrm{y}$

38.Bennett CE, Nsengimana J, Bostock JA, Cymbalista C, Futers TS, Knight BL, McCormack LJ, Prasad UK, Riches K, Rolton D, et al. CCAAT/enhancer binding protein alpha, beta and delta gene variants: associations with obesity related phenotypes in the Leeds Family Study. Diab Vasc Dis Res. 2010;7(3):195-203. doi:10.1177/1479164110366274

39. Killion EA, Reeves AR, El Azzouny MA, Yan QW, Surujon D, Griffin JD, Bowman TA, Wang C, Matthan NR, Klett EL, et al. A role for long-chain acyl-CoA synthetase-4 (ACSL4) in diet-induced phospholipid remodeling and obesity-associated adipocyte dysfunction. Mol Metab. 2018;9:43-56. doi:10.1016/j.molmet.2018.01.012

40.Cheng J, Song J, He X, Zhang M, Hu S, Zhang S, Yu Q, Yang P, Xiong F, Wang DW, et al. Loss of Mbd2 Protects Mice Against High-Fat DietInduced Obesity and Insulin Resistance by Regulating the Homeostasis of Energy Storage and Expenditure. Diabetes. 2016;65(11):3384-3395. doi:10.2337/db16-0151

41.An M, Ryu DR, Won Park J, Ha Choi J, Park EM, Eun Lee K, Woo M, Kim M. ULK1 prevents cardiac dysfunction in obesity through autophagymeditated regulation of lipid metabolism. Cardiovasc Res. 2017;113(10):1137-1147. doi:10.1093/cvr/cvx064

42.Hofmann T, Weibert E, Ahnis A, Obbarius A, Elbelt U, Rose M, Klapp BF, Stengel A. Alterations of circulating NUCB2/nesfatin-1 during short term therapeutic improvement of anxiety in obese inpatients. Psychoneuroendocrinology. 2017;79:107-115. doi:10.1016/j.psyneuen.2017.02.021

43.Ma W, Lu S, Sun T, Wang X, Ma Y, Zhang X, Zhao R, Wang Y. Twist 1 regulates the expression of PPAR $\gamma$ during hormone-induced 3T3-L1 
preadipocyte differentiation: a possible role in obesity and associated diseases. Lipids Health Dis. 2014;13:132. doi:10.1186/1476-511X-13-132

44.Rodríguez-Rodero S, Menéndez-Torre E, Fernández-Bayón G, MoralesSánchez P, Sanz L, Turienzo E, González JJ, Martinez-Faedo C, SuarezGutiérrez L, Ares J, et al. Altered intragenic DNA methylation of HOOK2 gene in adipose tissue from individuals with obesity and type 2 diabetes. PLoS One. 2017;12(12):e0189153. doi:10.1371/journal.pone.0189153

45.Belalcazar LM, Papandonatos GD, McCaffery JM, Peter I, Pajewski NM, Erar B, Allred ND, Balasubramanyam A, Bowden DW, Brautbar A, et al. A common variant in the CLDN7/ELP5 locus predicts adiponectin change with lifestyle intervention and improved fitness in obese individuals with diabetes. Physiol Genomics. 2015;47(6):215-224. doi:10.1152/physiolgenomics.00109.2014

46. Reilly SM, Chiang SH, Decker SJ, Chang L, Uhm M, Larsen MJ, Rubin JR, Mowers J, White NM, Hochberg I, et al. An inhibitor of the protein kinases TBK1 and IKK- $\square$ improves obesity-related metabolic dysfunctions in mice. Nat Med. 2013;19(3):313-321. doi:10.1038/nm.3082

47.Wang L, Mazagova M, Pan C, Yang S, Brandl K, Liu J, Reilly SM, Wang Y, Miao Z, Loomba R, et al. YIPF6 controls sorting of FGF21 into COPII vesicles and promotes obesity. Proc Natl Acad Sci U S A. 2019;116(30):15184-15193. doi:10.1073/pnas.1904360116

48.Garcia-Valdes L, Campoy C, Hayes H, Florido J, Rusanova I, Miranda MT, McArdle HJ. The impact of maternal obesity on iron status, placental transferrin receptor expression and hepcidin expression in human pregnancy. Int J Obes (Lond). 2015;39(4):571-578. doi:10.1038/ijo.2015.3

49.Reeves VL, Trybula JS, Wills RC, Goodpaster BH, Dubé JJ, Kienesberger PC, Kershaw EE. Serum Autotaxin/ENPP2 correlates with insulin resistance in older humans with obesity. Obesity (Silver Spring). 2015;23(12):23712376. doi:10.1002/oby.21232

50.Lim R, Lappas M. Slit2 exerts anti-inflammatory actions in human placenta and is decreased with maternal obesity. Am J Reprod Immunol. 2015;73(1):66-78. doi:10.1111/aji.12334

51.Khalifeh-Soltani A, McKleroy W, Sakuma S, Cheung YY, Tharp K, Qiu Y, Turner SM, Chawla A, Stahl A, Atabai K. Mfge8 promotes obesity by 
mediating the uptake of dietary fats and serum fatty acids. Nat Med. 2014;20(2):175-183. doi:10.1038/nm.3450

52.Bidu C, Escoula Q, Bellenger S, Spor A, Galan M, Geissler A, Bouchot A, Dardevet D, Morio B, Cani PD, et al. The Transplantation of $\omega 3$ PUFAAltered Gut Microbiota of fat-1 Mice to Wild-Type Littermates Prevents Obesity and Associated Metabolic Disorders. Diabetes. 2018;67(8):15121523. doi: $10.2337 / \mathrm{db} 17-1488$

53.Leelalertlauw C, Korwutthikulrangsri M, Mahachoklertwattana P, Chanprasertyothin S, Khlairit P, Pongratanakul S, Poomthavorn P. Serum glypican 4 level in obese children and its relation to degree of obesity. Clin Endocrinol (Oxf). 2017;87(6):689-695. doi:10.1111/cen.13435

54.McCulloch LJ, Rawling TJ, Sjöholm K, Franck N, Dankel SN, Price EJ, Knight $\mathrm{B}$, Liversedge $\mathrm{NH}$, Mellgren $\mathrm{G}$, Nystrom $\mathrm{F}$, et al. COL6A3 is regulated by leptin in human adipose tissue and reduced in obesity. Endocrinology. 2015;156(1):134-146. doi:10.1210/en.2014-1042

55.Oberauer R, Rist W, Lenter MC, Hamilton BS, Neubauer H. EGFL6 is increasingly expressed in human obesity and promotes proliferation of adipose tissue-derived stromal vascular cells. Mol Cell Biochem. 2010;343(1-2):257-269. doi:10.1007/s11010-010-0521-7

56.Jargaud V, Bour S, Tercé F, Collet X, Valet P, Bouloumié A, Guillemot JC, Mauriège $\mathrm{P}$, Jalkanen $\mathrm{S}$, Stolen $\mathrm{C}$, et al. Obesity of mice lacking VAP1/SSAO by Aoc3 gene deletion is reproduced in mice expressing a mutated vascular adhesion protein-1 (VAP-1) devoid of amine oxidase activity. J Physiol Biochem. 2020;10.1007/s13105-020-00756-y. doi:10.1007/s13105020-00756-y

57.Tan JT, McLennan SV, Williams PF, Rezaeizadeh A, Lo LW, Bonner JG, Twigg SM. Connective tissue growth factor/CCN-2 is upregulated in epididymal and subcutaneous fat depots in a dietary-induced obesity model. Am J Physiol Endocrinol Metab. 2013;304(12):E1291-E1302. doi:10.1152/ajpendo.00654.2012

58. Michurina SV, Ishchenko IY, Arkhipov SA, Klimontov VV, Rachkovskaya LN, Konenkov VI, Zavyalov EL. Effects of Melatonin, Aluminum Oxide, and Polymethylsiloxane Complex on the Expression of LYVE-1 in the Liver of Mice with Obesity and Type 2 Diabetes Mellitus. Bull Exp Biol Med. 2016;162(2):269-272. doi:10.1007/s10517-016-3592-y 
59.Redonnet A, Bonilla S, Noël-Suberville C, Pallet V, Dabadie H, Gin H, Higueret P. Relationship between peroxisome proliferator-activated receptor gamma and retinoic acid receptor alpha gene expression in obese human adipose tissue. Int J Obes Relat Metab Disord. 2002;26(7):920-927. doi:10.1038/sj.ijo.0802025

60.Errera FI, Canani LH, Yeh E, Kague E, Armelin-Corrêa LM, Suzuki OT, Tschiedel B, Silva ME, Sertié AL, Passos-Bueno MR. COL18A1 is highly expressed during human adipocyte differentiation and the SNP c.1136C > T in its "frizzled" motif is associated with obesity in diabetes type 2 patients. An Acad Bras Cienc. 2008;80(1):167-177. doi:10.1590/s000137652008000100012

61.Paine A, Woeller CF, Zhang H, de la Luz Garcia-Hernandez M, Huertas N, Xing L, Phipps RP, Ritchlin CT. Thy1 is a positive regulator of osteoblast differentiation and modulates bone homeostasis in obese mice. FASEB J. 2018;32(6):3174-3183. doi:10.1096/fj.201701379R

62.Wu RX, Dong YY, Yang PW, Wang L, Deng YH, Zhang HW, Huang XY. CD36- and obesity-associated granulosa cells dysfunction. Reprod Fertil Dev. 2019;31(5):993-1001. doi:10.1071/RD18292

63. Gao X, van der Veen JN, Zhu L, Chaba T, Ordoñez M, Lingrell S, Koonen DP, Dyck JR, Gomez-Muñoz A, Vance DE, et al. Vagus nerve contributes to the development of steatohepatitis and obesity in phosphatidylethanolamine N-methyltransferase deficient mice. J Hepatol. 2015;62(4):913-920. doi:10.1016/j.jhep.2014.11.026

64.Parikh D, Riascos-Bernal DF, Egaña-Gorroño L, Jayakumar S, Almonte V, Chinnasamy P, Sibinga NES. Allograft inflammatory factor-1-like is not essential for age dependent weight gain or HFD-induced obesity and glucose insensitivity. Sci Rep. 2020;10(1):3594. doi:10.1038/s41598-020-60433-4

65.Bush NR, Allison AL, Miller AL, Deardorff J, Adler NE, Boyce WT. Socioeconomic Disparities in Childhood Obesity Risk: Association With an Oxytocin Receptor Polymorphism. JAMA Pediatr. 2017;171(1):61-67. doi:10.1001/jamapediatrics.2016.2332

66.Kim Y, Bayona PW, Kim M, Chang J, Hong S, Park Y, Budiman A, Kim YJ, Choi CY, Kim WS, et al. Macrophage Lamin A/C Regulates Inflammation and the Development of Obesity-Induced Insulin Resistance. Front Immunol. 2018;9:696. doi:10.3389/fimmu.2018.00696 
67.Cereijo R, Quesada-López T, Gavaldà-Navarro A, Tarascó J, Pellitero S, Reyes M, Puig-Domingo M, Giralt M, Sánchez-Infantes D, Villarroya F. The chemokine CXCL14 is negatively associated with obesity and concomitant type-2 diabetes in humans. Int $\mathrm{J}$ Obes (Lond). 2021;10.1038/s41366-020-00732-y. doi:10.1038/s41366-020-00732-y

68.Xie L, Wang PX, Zhang P, Zhang XJ, Zhao GN, Wang A, Guo J, Zhu X, Zhang Q, Li H. DKK3 expression in hepatocytes defines susceptibility to liver steatosis and obesity. J Hepatol. 2016;65(1):113-124. doi:10.1016/j.jhep.2016.03.008

69.Tabata M, Kadomatsu T, Fukuhara S, Miyata K, Ito Y, Endo M, Urano T, Zhu HJ, Tsukano H, Tazume H, et al. Angiopoietin-like protein 2 promotes chronic adipose tissue inflammation and obesity-related systemic insulin resistance. Cell Metab. 2009;10(3):178-188. doi:10.1016/j.cmet.2009.08.003 70.Zhu Q, Xue K, Guo HW, Deng FF, Yang YH. Interaction of the CMTM7 rs347134 Polymorphism with Dietary Patterns and the Risk of Obesity in Han Chinese Male Children. Int $J$ Environ Res Public Health. 2020;17(5):1515. doi:10.3390/ijerph17051515

71.Wang K, Zhou Q, He Q, Tong G, Zhao Z, Duan T. The possible role of AhR in the protective effects of cigarette smoke on preeclampsia. Med Hypotheses. 2011;77(5):872-874. doi:10.1016/j.mehy.2011.07.061

72. Gratton AM, Ye L, Brownfoot FC, Hannan NJ, Whitehead C, Cannon P, Deo M, Fuller PJ, Tong S, Kaitu'u-Lino TJ. Steroid sulfatase is increased in the placentas and whole blood of women with early-onset preeclampsia. Placenta. 2016;48:72-79. doi:10.1016/j.placenta.2016.10.008

73.Wan L, Sun D, Xie J, Du M, Wang P, Wang M, Lei Y, Wang H, Wang H, Dong M. Declined placental PLAC1 expression is involved in preeclampsia. Medicine (Baltimore).

2019;98(44):e17676. doi:10.1097/MD.0000000000017676

74.Pan T, He G, Chen M, Bao C, Chen Y, Liu G, Zhou M, Li S, Xu W, Liu X. Abnormal CYP11A1 gene expression induces excessive autophagy, contributing to the pathogenesis of preeclampsia. Oncotarget. 2017;8(52):89824-89836. doi:10.18632/oncotarget.21158

75.Zhao L, Triche EW, Walsh KM, Bracken MB, Saftlas AF, Hoh J, Dewan AT. Genome-wide association study identifies a maternal copy-number 
deletion in PSG11 enriched among preeclampsia patients. BMC Pregnancy Childbirth. 2012;12:61. doi:10.1186/1471-2393-12-61

76.Li W, Geng L, Liu X, Gui W, Qi H. Recombinant adiponectin alleviates abortion in mice by regulating Th17/Treg imbalance via p38MAPK-STAT5 pathway. Biol Reprod. 2019;100(4):1008-1017. doi:10.1093/biolre/ioy251

77. Gierman LM, Silva GB, Pervaiz Z, Rakner JJ, Mundal SB, Thaning AJ, Nervik I, Elschot M, Mathew S, Thomsen LCV, et al. TLR3 expression by maternal and fetal cells at the maternal-fetal interface in normal and preeclamptic pregnancies. J Leukoc Biol. 2020;10.1002/JLB.3MA0620728RR. doi:10.1002/JLB.3MA0620-728RR

78.Piñuñuri R, Castaño-Moreno E, Llanos MN, Ronco AM. Epigenetic regulation of folate receptor- $\alpha$ (FOLR1) in human placenta of preterm newborns. Placenta. 2020;94:20-25. doi:10.1016/j.placenta.2020.03.009

79. White BG, Williams SJ, Highmore K, Macphee DJ. Small heat shock protein 27 (Hsp27) expression is highly induced in rat myometrium during late pregnancy and labour. Reproduction. 2005;129(1):115-126. doi:10.1530/rep.1.00426

80.Torres-Salazar Q, Martínez-López Y, Reyes-Romero M, Pérez-Morales R, Sifuentes-Álvarez A, Salvador-Moysén J. Differential Methylation in Promoter Regions of the Genes NR3C1 and HSP90AA1, Involved in the Regulation, and Bioavailability of Cortisol in Leukocytes of Women With Preeclampsia. Front Med (Lausanne). 2020;7:206. doi:10.3389/fmed.2020.00206

81.Xu Y, Sui L, Qiu B, Yin X, Liu J, Zhang X. ANXA4 promotes trophoblast invasion via the PI3K/Akt/eNOS pathway in preeclampsia. Am J Physiol Cell Physiol. 2019;316(4):C481-C491. doi:10.1152/ajpcell.00404.2018

82.Kaitu'u-Lino TJ, Brownfoot FC, Hastie R, Chand A, Cannon P, Deo M, Tuohey L, Whitehead C, Hannan NJ, Tong S. Activating Transcription Factor 3 Is Reduced in Preeclamptic Placentas and Negatively Regulates sFlt-1 (Soluble fms-Like Tyrosine Kinase 1), Soluble Endoglin, and Proinflammatory Cytokines in Placenta. Hypertension. 2017;70(5):10141024. doi:10.1161/HYPERTENSIONAHA.117.09548

83. Yung C, MacDonald TM, Walker SP, Cannon P, Harper A, Pritchard N, Hannan NJ, Kaitu'u-Lino TJ, Tong S. Death associated protein kinase 1 
(DAPK-1) is increased in preeclampsia. Placenta. 2019;88:1-7. doi:10.1016/j.placenta.2019.09.010

84.Zhu L, Lv R, Kong L, Li X. Reduced methylation downregulates CD39/ENTPD1 and ZDHHC14 to suppress trophoblast cell proliferation and invasion: Implications in preeclampsia. Pregnancy Hypertens. 2018;14:59-67. doi:10.1016/j.preghy.2018.03.012

85.Griesshammer M, Sadjadian P, Wille K. Contemporary management of patients with BCR-ABL1-negative myeloproliferative neoplasms during pregnancy. Expert Rev Hematol. 2018;11(9):697-706. doi:10.1080/17474086.2018.1506325

86. Textoris J, Ivorra D, Ben Amara A, Sabatier F, Ménard JP, Heckenroth H, Bretelle F, Mege JL. Evaluation of current and new biomarkers in severe preeclampsia: a microarray approach reveals the VSIG4 gene as a potential blood biomarker. PLoS One. 2013;8(12):e82638. doi:10.1371/journal.pone.0082638

87.Kelemu T, Erlandsson L, Seifu D, Abebe M, Teklu S, Storry JR, Hansson SR. Association of Maternal Regulatory Single Nucleotide Polymorphic CD99 Genotype with Preeclampsia in Pregnancies Carrying Male Fetuses in Ethiopian Women. Int J Mol Sci. 2020;21(16):5837. doi:10.3390/ijms21165837

88. Aref S, Goda H. Increased VWF antigen levels and decreased ADAMTS13 activity in preeclampsia. Hematology. 2013;18(4):237-241. doi:10.1179/1607845412Y.0000000070

89. Martineau T, Boutin M, Côté AM, Maranda B, Bichet DG, Auray-Blais C. Tandem mass spectrometry analysis of urinary podocalyxin and podocin in the investigation of podocyturia in women with preeclampsia and Fabry disease patients. Clin Chim Acta. 2019;495:67-75. doi:10.1016/j.cca.2019.03.1615

90. Onyangunga O, Moodley J, Odun-Ayo F, Naicker T. Immunohistochemical localization of podoplanin in the placentas of HIV-positive preeclamptic women. Turk J Med Sci. 2018;48(5):916-924. doi:10.3906/sag-1706-88

91.Li L, Zhang X, Hong SL, Chen Y, Ren GH. Long non-coding HOTTIP regulates preeclampsia by inhibiting RND3. Eur Rev Med Pharmacol Sci. 2018;22(11):3277-3285. doi:10.26355/eurrev_201806_15146 
92.Gogiel T, Galewska Z, Romanowicz L, Jaworski S, Bańkowski E. Preeclampsia-associated alterations in decorin, biglycan and versican of the umbilical cord vein wall. Eur J Obstet Gynecol Reprod Biol. 2007;134(1):51-56. doi:10.1016/j.ejogrb.2006.10.003

93.Hirschi KM, Tsai KYF, Davis T, Clark JC, Knowlton MN, Bikman BT, Reynolds PR, Arroyo JA. Growth arrest-specific protein-6/AXL signaling induces preeclampsia in rats $\dagger$. Biol Reprod. 2020;102(1):199-210. doi:10.1093/biolre/ioz140

94. Arishe OO, Ebeigbe AB, Webb RC. Mechanotransduction and Uterine Blood Flow in Preeclampsia: The Role of Mechanosensing Piezo 1 Ion Channels. Am J Hypertens. 2020;33(1):1-9. doi:10.1093/ajh/hpz158

95.Ji Y, Zhou L, Wang G, Qiao Y, Tian Y, Feng Y. Role of LAMA4 Gene in Regulating Extravillous Trophoblasts in Pathogenesis of Preeclampsia. Med Sci Monit. 2019;25:9630-9636. doi:10.12659/MSM.917402

96.Du F, Zhang Y, Xu Q, Teng Y, Tao M, Chen AF, Jiang R. Preeclampsia serum increases CAV1 expression and cell permeability of human renal glomerular endothelial cells via down-regulating miR-199a-5p, miR-199b5p, miR-204. Placenta. 2020;99:141-151. doi:10.1016/j.placenta.2020.07.011

97. Shimanuki Y, Mitomi H, Fukumura Y, Makino S, Itakura A, Yao T, Takeda S. Alteration of Delta-like ligand 1 and Notch 1 receptor in various placental disorders with special reference to early onset preeclampsia. Hum Pathol. 2015;46(8):1129-1137. doi:10.1016/j.humpath.2015.03.013

98. Todd N, McNally R, Alqudah A, Jerotic D, Suvakov S, Obradovic D, Hoch D, Hombrebueno JR, Campos GL, Watson CJ, et al. Role of A Novel Angiogenesis FKBPL-CD44 Pathway in Preeclampsia Risk Stratification and Mesenchymal Stem Cell Treatment. J Clin Endocrinol Metab. 2021;106(1):26-41. doi:10.1210/clinem/dgaa403

99.Ding H, Dai Y, Lei Y, Wang Z, Liu D, Li R, Shen L, Gu N, Zheng M, Zhu $\mathrm{X}$, et al. Upregulation of CD81 in trophoblasts induces an imbalance of Treg/Th17 cells by promoting IL-6 expression in preeclampsia. Cell Mol Immunol. 2019;16(1):302-312. doi:10.1038/s41423-018-0186-9

100. Brkić J, Dunk C, Shan Y, O'Brien JA, Lye P, Qayyum S, Yang P, Matthews SG, Lye SJ, Peng C. Differential Role of Smad2 and Smad3 in the Acquisition of an Endovascular Trophoblast-Like Phenotype and 
Preeclampsia. Front Endocrinol (Lausanne). 2020;11:436. doi:10.3389/fendo.2020.00436

101. Yang X, Ding Y, Yang M, Yu L, Hu Y, Deng Y. Nestin Improves Preeclampsia-Like Symptoms by Inhibiting Activity of Cyclin-Dependent Kinase 5. Kidney Blood Press Res. 2018;43(2):616-627. doi:10.1159/000489146

102. Lala PK, Nandi P. Mechanisms of trophoblast migration, endometrial angiogenesis in preeclampsia: The role of decorin. Cell Adh Migr. 2016;10(1-2):111-125. doi:10.1080/19336918.2015.1106669

103. Zhao L, Dewan AT, Bracken MB. Association of maternal AGTR1 polymorphisms and preeclampsia: a systematic review and meta-analysis. J Matern Fetal Neonatal Med. 2012;25(12):2676-2680. doi:10.3109/14767058.2012.708370

104. Lim R, Barker G, Lappas M. SLIT3 is increased in supracervical human foetal membranes and in labouring myometrium and regulates proinflammatory mediators. Am J Reprod Immunol. 2014;71(4):297-311. doi:10.1111/aji.12181

105. Kristensen K, Wide-Swensson D, Schmidt C, Blirup-Jensen S, Lindström V, Strevens H, Grubb A. Cystatin C, beta-2-microglobulin and beta-trace protein in pre-eclampsia. Acta Obstet Gynecol Scand. 2007;86(8):921-926. doi:10.1080/00016340701318133

106. Tang J, Wang D, Lu J, Zhou X. MiR-125b participates in the occurrence of preeclampsia by regulating the migration and invasion of extravillous trophoblastic cells through STAT3 signaling pathway. J Recept Signal Transduct Res. 2020;1-7. doi:10.1080/10799893.2020.1806318

107. Abid N, Embola J, Tryfonos Z, Bercher J, Ashton SV, Khalil A, Thilaganathan B, Cartwright JE, Whitley GS. Regulation of stanniocalcin-1 secretion by BeWo cells and first trimester human placental tissue from normal pregnancies and those at increased risk of developing preeclampsia. FASEB J. 2020;34(5):6086-6098. doi:10.1096/fj.201902426R

108. Namlı Kalem M, Kalem Z, Yüce T, Soylemez F. ADAMTS 1, 4, 12, and 13 levels in maternal blood, cord blood, and placenta in preeclampsia. Hypertens Pregnancy. 2018;37(1):9-17. doi:10.1080/10641955.2017.1397690 
109. Majchrzak-Celińska A, Kosicka K, Paczkowska J, Główka FK, Bręborowicz GH, Krzyścin M, Siemiątkowska A, Szaumkessel M, BaerDubowska W. HSD11B2, RUNX3, and LINE-1 Methylation in Placental DNA of Hypertensive Disorders of Pregnancy Patients. Reprod Sci. 2017;24(11):1520-1531. doi:10.1177/1933719117692043

110. Shimodaira M, Nakayama T, Sato I, Sato N, Izawa N, Mizutani Y,

Furuya K, Yamamoto T.Estrogen synthesis genes CYP19A1, HSD3B1, and HSD3B2 in hypertensive disorders of pregnancy. Endocrine. 2012;42(3):700-707. doi:10.1007/s12020-012-9699-7

111. Saxena R, Bjonnes A, Prescott J, Dib P, Natt P, Lane J, Lerner M, Cooper JA, Ye Y, Li KW, et al. Genome-wide association study identifies variants in casein kinase II (CSNK2A2) to be associated with leukocyte telomere length in a Punjabi Sikh diabetic cohort. Circ Cardiovasc Genet. 2014;7(3):287-295. doi:10.1161/CIRCGENETICS.113.000412

112. Yang W, Wang J, Chen Z, Chen J, Meng Y, Chen L, Chang Y, Geng B, Sun L, Dou L, et al. NFE2 Induces miR-423-5p to Promote Gluconeogenesis and Hyperglycemia by Repressing the Hepatic FAM3AATP-Akt Pathway. Diabetes. 2017;66(7):1819-1832. doi:10.2337/db161172

113. Gloyn AL, Desai M, Clark A, Levy JC, Holman RR, Frayling TM, Hattersley AT, Ashcroft SJ. Human calcium/calmodulin-dependent protein kinase II gamma gene (CAMK2G): cloning, genomic structure and detection of variants in subjects with type II diabetes. Diabetologia. 2002;45(4):580583. doi:10.1007/s00125-002-0779-8

114. Li JY, Tao F, Wu XX, Tan YZ, He L, Lu H. Common RASGRP1 Gene Variants That Confer Risk of Type 2 Diabetes. Genet Test Mol Biomarkers. 2015;19(8):439-443. doi:10.1089/gtmb.2015.0005

115. Afarideh M, Zaker Esteghamati V, Ganji M, Heidari B, Esteghamati S, Lavasani S, Ahmadi M, Tafakhori A, Nakhjavani M, Esteghamati A.Associations of Serum S100B and S100P With the Presence and Classification of Diabetic Peripheral Neuropathy in Adults With Type 2 Diabetes: A Case-Cohort Study. Can J Diabetes. 2019;43(5):336-344.e2. doi:10.1016/j.jcjd.2019.01.003

116. Zhang S, Xiao J, Ren Q, Han X, Tang Y, Yang W, Zhou X, Ji L. Association of serine racemase gene variants with type 2 diabetes in the 
Chinese Han population. J Diabetes Investig. 2014;5(3):286-289. doi:10.1111/jdi.12145

117. Robbins RD, Tersey SA, Ogihara T, Gupta D, Farb TB, Ficorilli J, Bokvist K, Maier B, Mirmira RG. Inhibition of deoxyhypusine synthase enhances islet $\{$ beta $\}$ cell function and survival in the setting of endoplasmic reticulum stress and type 2 diabetes. J Biol Chem. 2010;285(51):3994339952. doi:10.1074/jbc.M110.170142

118. Belgardt BF, Lammert E. DYRK1A: A Promising Drug Target for Islet Transplant-Based Diabetes Therapies. Diabetes. 2016;65(6):1496-1498. doi:10.2337/dbi16-0013

119. Yoon CH, Choi YE, Cha YR, Koh SJ, Choi JI, Kim TW, Woo SJ, Park YB, Chae IH, Kim HS. Diabetes-Induced Jagged1 Overexpression in Endothelial Cells Causes Retinal Capillary Regression in a Murine Model of Diabetes Mellitus: Insights Into Diabetic Retinopathy. Circulation. 2016;134(3):233-247. doi:10.1161/CIRCULATIONAHA.116.014411

120. Gaikwad AB, Gupta J, Tikoo K. Epigenetic changes and alteration of Fbn1 and Col3A1 gene expression under hyperglycaemic and hyperinsulinaemic conditions. Biochem J. 2010;432(2):333-341. doi:10.1042/BJ20100414

121. Alessi MC, Nicaud V, Scroyen I, Lange C, Saut N, Fumeron F, Marre M, Lantieri O, Fontaine-Bisson B, Juhan-Vague I, et al. Association of vitronectin and plasminogen activator inhibitor-1 levels with the risk of metabolic syndrome and type 2 diabetes mellitus. Results from the D.E.S.I.R. prospective cohort. Thromb Haemost. 2011;106(3):416-422. doi:10.1160/TH11-03-0179

122. Yang Q, Wang WW, Ma P, Ma ZX, Hao M, Adelusi TI, Lei-Du, Yin $\mathrm{XX}, \mathrm{Lu} \mathrm{Q}$. Swimming training alleviated insulin resistance through Wnt3a/ $\beta$-catenin signaling in type 2 diabetic rats. Iran J Basic Med Sci. 2017;20(11):1220-1226. doi:10.22038/IJBMS.2017.9473

123. Fang H, Luo X, Wang Y, Liu N, Fu C, Wang H, Fang Y, Shi W, Zhang $\mathrm{Y}$, Zeng $\mathrm{C}$, et al. Correlation between single nucleotide polymorphisms of the ACTA2 gene and coronary artery stenosis in patients with type 2 diabetes mellitus. Exp Ther Med. 2014;7(4):970-976. doi:10.3892/etm.2014.1510 
124. Xu X, Fang K, Wang L, Liu X, Zhou Y, Song Y. Local Application of Semaphorin 3A Combined with Adipose-Derived Stem Cell Sheet and Anorganic Bovine Bone Granules Enhances Bone Regeneration in Type 2 Diabetes Mellitus Rats. Stem Cells Int. 2019;2019:2506463. doi:10.1155/2019/2506463

125. Zhao K, Ding W, Zhang Y, Ma K, Wang D, Hu C, Liu J, Zhang X. Variants in the RARRES2 gene are associated with serum chemerin and increase the risk of diabetic kidney disease in type 2 diabetes. Int $\mathrm{J}$ Biol Macromol. 2020;165(Pt A):1574-1580. doi:10.1016/j.ijbiomac.2020.10.030

126. Fisher E, Schreiber S, Joost HG, Boeing H, Döring F. A two-step association study identifies CAV2 rs2270188 single nucleotide polymorphism interaction with fat intake in type 2 diabetes risk. J Nutr. 2011;141(2):177-181. doi:10.3945/jn.110.124206

127. Meng S, Cao JT, Zhang B, Zhou Q, Shen CX, Wang CQ. Downregulation of microRNA-126 in endothelial progenitor cells from diabetes patients, impairs their functional properties, via target gene Spred-1. J Mol Cell Cardiol. 2012;53(1):64-72. doi:10.1016/j.yjmcc.2012.04.003

128. Santiago JL, Martínez A, de la Calle H, Fernández-Arquero M, Figueredo MA, de la Concha EG, Urcelay E. Evidence for the association of the SLC22A4 and SLC22A5 genes with type 1 diabetes: a case control study. BMC Med Genet. 2006;7:54. doi:10.1186/1471-2350-7-54

129. Auburger G, Gispert S, Lahut S, Omür O, Damrath E, Heck M, Başak

N. 12q24 locus association with type 1 diabetes: SH2B3 or ATXN2?.

World J Diabetes. 2014;5(3):316-327. doi:10.4239/wjd.v5.i3.316

130. Qu HQ, Marchand L, Szymborski A, Grabs R, Polychronakos C. The association between type 1 diabetes and the ITPR 3 gene polymorphism due to linkage disequilibrium with HLA class II. Genes Immun. 2008;9(3):264266. doi:10.1038/gene.2008.12

131. Śnit M, Nabrdalik K, Długaszek M, Gumprecht J, Trautsolt W, Górczyńska-Kosiorz S, Grzeszczak W. Association of rs 3807337 polymorphism of CALD1 gene with diabetic nephropathy occurrence in type 1 diabetes - preliminary results of a family-based study. Endokrynol Pol. 2017;68(1):13-17. doi:10.5603/EP.2017.0003

132. Hjortebjerg R, Tarnow L, Jorsal A, Parving HH, Rossing P, Bjerre M, Frystyk J. IGFBP-4 Fragments as Markers of Cardiovascular Mortality in 
Type 1 Diabetes Patients With and Without Nephropathy. J Clin Endocrinol Metab. 2015;100(8):3032-3040. doi:10.1210/jc.2015-2196

133. Krishnan M, Murphy R, Okesene-Gafa KAM, Ji M, Thompson JMD, Taylor RS, Merriman TR, McCowan LME, McKinlay CJD. The Pacificspecific CREBRF rs373863828 allele protects against gestational diabetes mellitus in Māori and Pacific women with obesity. Diabetologia. 2020;63(10):2169-2176. doi:10.1007/s00125-020-05202-8

134. Hu S, Yan J, You Y, Yang G, Zhou H, Li X, Liao X, Tan H. Association of polymorphisms in STRA6 gene with gestational diabetes mellitus in a Chinese Han population. Medicine (Baltimore). 2019;98(11):e14885. doi:10.1097/MD.0000000000014885

135. Martins RS, Ahmed T, Farhat S, Shahid S, Fatima SS. Epidermal growth factor receptor rs17337023 polymorphism in hypertensive gestational diabetic women: A pilot study. World J Diabetes. 2019;10(7):396-402. doi:10.4239/wjd.v10.i7.396

136. Prieto-Sánchez MT, Ruiz-Palacios M, Blanco-Carnero JE, Pagan A, Hellmuth C, Uhl O, Peissner W, Ruiz-Alcaraz AJ, Parrilla JJ, Koletzko B, et al. Placental MFSD2a transporter is related to decreased DHA in cord blood of women with treated gestational diabetes. Clin Nutr. 2017;36(2):513-521. doi:10.1016/j.clnu.2016.01.014

137. Sugulle M, Dechend R, Herse F, Weedon-Fekjaer MS, Johnsen GM, Brosnihan KB, Anton L, Luft FC, Wollert KC, Kempf T, et al. Circulating and placental growth-differentiation factor 15 in preeclampsia and in pregnancy complicated by diabetes mellitus. Hypertension. 2009;54(1):106112. doi:10.1161/HYPERTENSIONAHA.109.130583

138. Zhao $\mathrm{H}$, Tao S. MiRNA-221 protects islet $\beta$ cell function in gestational diabetes mellitus by targeting PAK1. Biochem Biophys Res Commun. 2019;520(1):218-224. doi:10.1016/j.bbrc.2019.09.139

139. Siddiqui K, George TP, Nawaz SS, Joy SS. VCAM-1, ICAM-1 and selectins in gestational diabetes mellitus and the risk for vascular disorders. Future Cardiol. 2019;15(5):339-346. doi:10.2217/fca-2018-0042

140. Han N, Fang HY, Jiang JX, Xu Q. Downregulation of microRNA-873 attenuates insulin resistance and myocardial injury in rats with gestational diabetes mellitus by upregulating IGFBP2. Am J Physiol Endocrinol Metab. 2020;318(5):E723-E735. doi:10.1152/ajpendo.00555.2018 
141. Lappas M. Insulin-like growth factor-binding protein 1 and 7 concentrations are lower in obese pregnant women, women with gestational diabetes and their fetuses. J Perinatol. 2015;35(1):32-38. doi:10.1038/jp.2014.144

142. Wang F, Xu C, Reece EA, Li X, Wu Y, Harman C, Yu J, Dong D, Wang C, Yang $\mathrm{P}$, et al. Protein kinase $\mathrm{C}$-alpha suppresses autophagy and induces neural tube defects via miR-129-2 in diabetic pregnancy. Nat Commun. 2017;8:15182. doi:10.1038/ncomms 15182

143. Artunc-Ulkumen B, Ulucay S, Pala HG, Cam S. Maternal serum ADAMTS-9 levels in gestational diabetes: a pilot study. J Matern Fetal Neonatal Med. 2017;30(12):1442-1445. doi:10.1080/14767058.2016.1219717

144. Blois SM, Gueuvoghlanian-Silva BY, Tirado-González I, Torloni MR, Freitag N, Mattar R, Conrad ML, Unverdorben L, Barrientos G, Knabl $\mathrm{J}$, et al. Getting too sweet: galectin-1 dysregulation in gestational diabetes mellitus. Mol Hum 2014;20(7):644-649. doi:10.1093/molehr/gau021

145. Vacínová $\mathrm{G}$, Vejražková $\mathrm{D}$, Lukášová $\mathrm{P}$, Lischková $\mathrm{O}$, Dvořáková $\mathrm{K}$, Rusina R, Holmerová I, Vaňková $\mathrm{H}$, Včelák $\mathrm{J}$, Bendlová $\mathrm{B}$, et al. Associations of polymorphisms in the candidate genes for Alzheimer's disease BIN1, CLU, CR1 and PICALM with gestational diabetes and impaired glucose tolerance. Mol Biol Rep. 2017;44(2):227-231. doi:10.1007/s11033-017-4100-9

146. Vilmi-Kerälä T, Lauhio A, Tervahartiala T, Palomäki O, Uotila J, Sorsa T, Palomäki A. Subclinical inflammation associated with prolonged TIMP-1 upregulation and arterial stiffness after gestational diabetes mellitus: a hospital-based cohort study. Cardiovasc Diabetol. 2017;16(1):49. doi:10.1186/s12933-017-0530-x

147. Aquila G, Vieceli Dalla Sega F, Marracino L, Pavasini R, Cardelli LS, Piredda A, Scoccia A, Martino V, Fortini F, Bononi I et al Ticagrelor Increases SIRT1 and HES1 mRNA Levels in Peripheral Blood Cells from Patients with Stable Coronary Artery Disease and Chronic Obstructive Pulmonary Disease. Int J Mol Sci. 2020;21(5):1576. doi:10.3390/ijms21051576 
148. Chen Y, Wu S, Zhang XS, Wang DM, Qian CY. MicroRNA-489 promotes cardiomyocyte apoptosis induced by myocardial ischemiareperfusion injury through inhibiting SPIN1. Eur Rev Med Pharmacol Sci. 2019;23(15):6683-6690. doi:10.26355/eurrev_201908_18559

149. Xie H, Zhang E, Hong N, Fu Q, Li F, Chen S, Yu Y, Sun K. Identification of TBX2 and TBX3 variants in patients with conotruncal heart defects by target sequencing. Hum Genomics. 2018;12(1):44. doi:10.1186/s40246-018-0176-0

150. Zhang S, Lin X, Li G, Shen X, Niu D, Lu G, Fu X, Chen Y, Cui M, Bai Y. Knockout of Eva1a leads to rapid development of heart failure by impairing autophagy. Cell Death Dis. 2017;8(2):e2586. doi:10.1038/cddis.2017.17

151. Aspit L, Levitas A, Etzion S, Krymko H, Slanovic L, Zarivach R, Etzion Y, Parvari R. CAP2 mutation leads to impaired actin dynamics and associates with supraventricular tachycardia and dilated cardiomyopathy. J Med Genet. 2019;56(4):228-235. doi:10.1136/jmedgenet-2018-105498

152. Akadam-Teker B, Ozkara G, Kurnaz-Gomleksiz O, Bugra Z, Teker E, Ozturk O, Yilmaz-Aydogan H. BMP1 5'UTR $\square+\square 104$ T/C gene variation: can be a predictive marker for serum HDL and apoprotein A1 levels in male patients with coronary heart disease. Mol Biol Rep. 2018;45(5):1269-1276. doi:10.1007/s11033-018-4283-8

153. Jiang B, Liu Y, Liang P, Li Y, Liu Z, Tong Z, Lv Q, Liu M, Xiao X. MicroRNA-126a-5p enhances myocardial ischemia-reperfusion injury through suppressing Hspb8 expression. Oncotarget. 2017;8(55):9417294187. doi:10.18632/oncotarget.21613

154. Cetinkaya A, Berge B, Sen-Hild B, Troidl K, Gajawada P, Kubin N, Valeske K, Schranz D, Akintürk H, Schönburg M, et al. Radixin Relocalization and Nonmuscle $\alpha$-Actinin Expression Are Features of Remodeling Cardiomyocytes in Adult Patients with Dilated Cardiomyopathy. Dis $\quad$ Markers. 2020;2020:9356738. doi: $10.1155 / 2020 / 9356738$

155. Grond-Ginsbach C, Weber R, Haas J, Orberk E, Kunz S, Busse O, Hausser I, Brandt T, Wildemann B. Mutations in the COL5A1 coding sequence are not common in patients with spontaneous cervical artery dissections. Stroke. 1999;30(9):1887-1890. doi:10.1161/01.str.30.9.1887 
156. Dong Y, Zhai W, Xu Y. Bioinformatic gene analysis for potential biomarkers and therapeutic targets of diabetic nephropathy associated renal cell carcinoma. Transl Androl Urol. 2020;9(6):2555-2571. doi:10.21037/tau19-911

157. Chardon JW, Smith AC, Woulfe J, Pena E, Rakhra K, Dennie C, Beaulieu C, Huang L, Schwartzentruber J, Hawkins C, et al. LIMS2 mutations are associated with a novel muscular dystrophy, severe cardiomyopathy and triangular tongues. Clin Genet. 2015;88(6):558-564. doi:10.1111/cge. 12561

158. Chen H, Huang XN, Yan W, Chen K, Guo L, Tummalapali L, Dedhar S, St-Arnaud R, Wu C, Sepulveda JL. Role of the integrin-linked kinase/PINCH1/alpha-parvin complex in cardiac myocyte hypertrophy. Lab Invest. 2005;85(11):1342-1356. doi:10.1038/labinvest.3700345

159. Yamada Y, Sakuma J, Takeuchi I, Yasukochi Y, Kato K, Oguri M, Fujimaki T, Horibe H, Muramatsu M, Sawabe M, et al. Identification of EGFLAM, SPATC1L and RNASE13 as novel susceptibility loci for aortic aneurysm in Japanese individuals by exome-wide association studies. Int J Mol Med. 2017;39(5):1091-1100. doi:10.3892/ijmm.2017.2927

160. Hu YW, Guo FX, Xu YJ, Li P, Lu ZF, McVey DG, Zheng L, Wang $\mathrm{Q}$, Ye JH, Kang CM, et al. Long noncoding RNA NEXN-AS1 mitigates atherosclerosis by regulating the actin-binding protein NEXN. J Clin Invest. 2019;129(3):1115-1128. doi:10.1172/JCI98230

161. Bobik A, Kalinina N. Tumor necrosis factor receptor and ligand superfamily family members TNFRSF14 and LIGHT: new players in human atherogenesis. Arterioscler Thromb Vasc Biol. 2001;21(12):1873-1875

162. Schwanekamp JA, Lorts A, Sargent MA, York AJ, Grimes KM,

Fischesser DM, Gokey JJ, Whitsett JA, Conway SJ, Molkentin JD. TGFBI functions similar to periostin but is uniquely dispensable during cardiac injury. PLoS One. 2017;12(7):e0181945. doi:10.1371/journal.pone.0181945 163. Liu C, Zhang H, Chen Y, Wang S, Chen Z, Liu Z, Wang J. Identifying RBM47, HCK, CD53, TYROBP, and HAVCR2 as Hub Genes in Advanced Atherosclerotic Plaques by Network-Based Analysis and Validation. Front Genet. 2021;11:602908. doi:10.3389/fgene.2020.602908 164. Schroer AK, Bersi MR, Clark CR, Zhang Q, Sanders LH, Hatzopoulos AK, Force TL, Majka SM, Lal H, Merryman WD. Cadherin-11 
blockade reduces inflammation-driven fibrotic remodeling and improves outcomes after myocardial infarction. JCI Insight. 2019;4(18):e131545.doi:10.1172/jci.insight.131545

165. Raza ST, Abbas S, Eba A, Karim F, Wani IA, Rizvi S, Zaidi A, Mahdi F. Association of COL4A1 (rs605143, rs565470) and CD14 (rs2569190) genes polymorphism with coronary artery disease. Mol Cell Biochem. 2018;445(1-2):117-122. doi:10.1007/s11010-017-3257-9

166. Yang W, Ng FL, Chan K, Pu X, Poston RN, Ren M, An W, Zhang R,

Wu J, Yan S, et al. Coronary-Heart-Disease-Associated Genetic Variant at the COL4A1/COL4A2 Locus Affects COL4A1/COL4A2 Expression, Vascular Cell Survival, Atherosclerotic Plaque Stability and Risk of Myocardial Infarction. PLoS Genet. 2016;12(7):e1006127. doi:10.1371/journal.pgen.1006127

167. Azuaje F, Zhang L, Jeanty C, Puhl SL, Rodius S, Wagner DR. Analysis of a gene co-expression network establishes robust association between Col5a2 and ischemic heart disease. BMC Med Genomics. 2013;6:13. doi:10.1186/1755-8794-6-13

168. Durbin MD, O'Kane J, Lorentz S, Firulli AB, Ware SM. SHROOM3 is downstream of the planar cell polarity pathway and loss-of-function results in congenital heart defects. Dev Biol. 2020;464(2):124-136. doi:10.1016/j.ydbio.2020.05.013

169. Chowdhury B, Xiang B, Liu M, Hemming R, Dolinsky VW, TriggsRaine B. Hyaluronidase 2 Deficiency Causes Increased Mesenchymal Cells, Congenital Heart Defects, and Heart Failure. Circ Cardiovasc Genet. 2017;10(1):e001598. doi:10.1161/CIRCGENETICS.116.001598

170. Wang D, Fang J, Lv J, Pan Z, Yin X, Cheng H, Guo X.Novel polymorphisms in PDLIM3 and PDLIM5 gene encoding Z-line proteins increase risk of idiopathic dilated cardiomyopathy. J Cell Mol Med. 2019;23(10):7054-7062. doi:10.1111/jcmm.14607

171. Li J, Su H, Zhu Y, Cao Y, Ma X. ETS2 and microRNA-155 regulate the pathogenesis of heart failure through targeting and regulating GPR18 expression. Exp Ther Med. 2020;19(6):3469-3478. doi:10.3892/etm.2020.8642

172. Lv L, Li T, Li X, Xu C, Liu Q, Jiang H, Li Y, Liu Y, Yan H, Huang Q, et al. The lncRNA Plscr4 Controls Cardiac Hypertrophy by Regulating 
miR-214. Mol Ther Nucleic Acids. 2018;10:387-397. doi:10.1016/j.omtn.2017.12.018

173. Bertoli-Avella AM, Gillis E, Morisaki H, Verhagen JMA, de Graaf BM, van de Beek G, Gallo E, Kruithof BPT, et al. Mutations in a TGF- $\beta$ ligand, TGFB3, cause syndromic aortic aneurysms and dissections. J Am Coll Cardiol. 2015;65(13):1324-1336. doi:10.1016/j.jacc.2015.01.040

174. Grossman TR, Gamliel A, Wessells RJ, Taghli-Lamallem O, Jepsen K, Ocorr K, Korenberg JR, Peterson KL, Rosenfeld MG, Bodmer R, et al. Over-expression of DSCAM and COL6A2 cooperatively generates congenital heart defects. PLoS Genet. 2011;7(11):e1002344. doi:10.1371/journal.pgen.1002344

175. Andenæs K, Lunde IG, Mohammadzadeh N, Dahl CP, Aronsen JM, Strand ME, Palmero S, Sjaastad I, Christensen G, Engebretsen KVT, et al. The extracellular matrix proteoglycan fibromodulin is upregulated in clinical and experimental heart failure and affects cardiac remodeling. PLoS One. 2018;13(7):e0201422. doi:10.1371/journal.pone.0201422

176. Chen HX, Yang ZY, Hou HT, Wang J, Wang XL, Yang Q, Liu L, He GW. Novel mutations of TCTN3/LTBP2 with cellular function changes in congenital heart disease associated with polydactyly. J Cell Mol Med. 2020;24(23):13751-13762. doi:10.1111/jcmm. 15950

177. Flamant M, Placier S, Rodenas A, Curat CA, Vogel WF, Chatziantoniou C, Dussaule JC. Discoidin domain receptor 1 null mice are protected against hypertension-induced renal disease. J Am Soc Nephrol. 2006;17(12):3374-3381. doi:10.1681/ASN.2006060677

178. Wan F, Letavernier E, Abid S, Houssaini A, Czibik G, Marcos E, Rideau D, Parpaleix A, Lipskaia L, Amsellem V, et al. Extracellular Calpain/Calpastatin Balance Is Involved in the Progression of Pulmonary Hypertension. Am J Respir Cell Mol Biol. 2016;55(3):337-351. doi:10.1165/rcmb.2015-0257OC

179. Zhang Y, Shen J, He X, Zhang K, Wu S, Xiao B, Zhou X, Phillips $\mathrm{RS}$, Gao P, Jeunemaitre X, Zhu D. A rare variant at the KYNU gene is associated with kynureninase activity and essential hypertension in the Han Chinese population. Circ Cardiovasc Genet. 2011;4(6):687-694. doi:10.1161/CIRCGENETICS.110.959064 
180. Vallvé JC, Serra N, Zalba G, Fortuño A, Beloqui O, Ferre R, Ribalta J, Masana L. Two variants in the fibulin2 gene are associated with lower systolic blood pressure and decreased risk of hypertension. PLoS One. 2012;7(8):e43051. doi:10.1371/journal.pone.0043051

181. Heximer S, Husain M. A candidate hypertension gene: will SPON1 hold salt and water? Circ Res. 2007;100(7):940-942. doi:10.1161/01.RES.0000265134.57140.da

182. Selvarajah V, Mäki-Petäjä KM, Pedro L, Bruggraber SFA, Burling K, Goodhart AK, Brown MJ, McEniery CM, Wilkinson IB. Novel Mechanism for Buffering Dietary Salt in Humans: Effects of Salt Loading on Skin Sodium, Vascular Endothelial Growth Factor C, and Blood Pressure. Hypertension. 2017;70(5):930-937.

doi:10.1161/HYPERTENSIONAHA.117.10003

183. Jain M, Mann TD, Stulić M, Rao SP, Kirsch A, Pullirsch D, Strobl X, Rath C, Reissig L, Moreth K, et al. RNA editing of Filamin A pre-mRNA regulates vascular contraction and diastolic blood pressure. EMBO J. 2018;37(19):e94813. doi:10.15252/embj.201694813

184. Sun L, Lin P, Chen Y, Yu H, Ren S, Wang J, Zhao L, Du G. miR$182-3 \mathrm{p} / \mathrm{Myadm}$ contribute to pulmonary artery hypertension vascular remodeling via a KLF4/p21-dependent mechanism. Theranostics. 2020;10(12):5581-5599. doi:10.7150/thno.44687

185. Satomi-Kobayashi S, Ueyama T, Mueller S, Toh R, Masano T, Sakoda T, Rikitake Y, Miyoshi J, Matsubara H, Oh H, et al. Deficiency of nectin-2 leads to cardiac fibrosis and dysfunction under chronic pressure overload. Hypertension.

2009;54(4):825-831. doi:10.1161/HYPERTENSIONAHA.109.130443

186. Jiang J, Nakayama T, Shimodaira M, Sato N, Aoi N, Sato M, Izumi Y, Kasamaki Y, Ohta M, Soma M, et al. Haplotype of smoothelin gene associated with essential hypertension. Hereditas. 2012;149(5):178-185. doi:10.1111/j.1601-5223.2012.02242.x

187. Waghulde H, Cheng X, Galla S, Mell B, Cai J, Pruett-Miller SM, Vazquez G, Patterson A, Vijay Kumar M, Joe B.Attenuation of Microbiotal Dysbiosis and Hypertension in a CRISPR/Cas9 Gene Ablation Rat Model of GPER1.

Hypertension. 2018;72(5):1125-1132. doi:10.1161/HYPERTENSIONAHA.118.11175 
188. Dahal BK, Heuchel R, Pullamsetti SS, Wilhelm J, Ghofrani HA, Weissmann N, Seeger W, Grimminger F, Schermuly RT. Hypoxic pulmonary hypertension in mice with constitutively active platelet-derived growth factor receptor- $\beta$. Pulm Circ. 2011;1(2):259-268. doi:10.4103/20458932.83448

189. Thun GA, Imboden M, Berger W, Rochat T, Probst-Hensch NM. The association of a variant in the cell cycle control gene CCND1 and obesity on the development of asthma in the Swiss SAPALDIA study. J Asthma. 2013;50(2):147-154. doi:10.3109/02770903.2012.757776

190. Zhang T, Ji C, Shi R. miR-142-3p promotes pancreatic $\beta$ cell survival through targeting FOXO1 in gestational diabetes mellitus. Int J Clin Exp Pathol. 2019;12(5):1529-1538.

191. Wang H, She G, Zhou W, Liu K, Miao J, Yu B. Expression profile of circular RNAs in placentas of women with gestational diabetes mellitus. Endocr J. 2019;66(5):431-441. doi:10.1507/endocrj.EJ18-0291

192. Pheiffer C, Dias S, Rheeder P, Adam S. MicroRNA Profiling in HIVInfected South African Women with Gestational Diabetes Mellitus. Mol Diagn Ther. 2019;23(4):499-505. doi:10.1007/s40291-019-00404-2

193. Zhang C, Wang L, Chen J, Song F, Guo Y. Differential Expression of miR-136 in Gestational Diabetes Mellitus Mediates the High-GlucoseInduced Trophoblast Cell Injury through Targeting E2F1. Int J Genomics. 2020;2020:3645371. doi:10.1155/2020/3645371

194. Catanzaro G, Besharat ZM, Chiacchiarini M, Abballe L, Sabato C, Vacca A, Borgiani P, Dotta F, Tesauro M, Po A, et al. Circulating MicroRNAs in Elderly Type 2 Diabetic Patients. Int $\mathrm{J}$ Endocrinol. 2018;2018:6872635. doi:10.1155/2018/6872635

195. Demirsoy İH, Ertural DY, Balci Ş, Çınkır Ü, Sezer K, Tamer L, Aras N. Profiles of Circulating MiRNAs Following Metformin Treatment in Patients with Type 2 Diabetes. J Med Biochem. 2018;37(4):499-506. doi:10.2478/jomb-2018-0009

196. Kasimiotis H, Myers MA, Argentaro A, Mertin S, Fida S, Ferraro T, Olsson J, Rowley MJ, Harley VR. Sex-determining region Y-related protein SOX13 is a diabetes autoantigen expressed in pancreatic islets. Diabetes. 2000;49(4):555-561. doi:10.2337/diabetes.49.4.555 
197. Wang H, Shi J, Li B, Zhou Q, Kong X, Bei Y. MicroRNA Expression Signature in Human Calcific Aortic Valve Disease. Biomed Res Int. 2017;2017:4820275. doi:10.1155/2017/4820275

198. Xie H, Zhang E, Hong N, Fu Q, Li F, Chen S, Yu Y, Sun K. Identification of TBX2 and TBX3 variants in patients with conotruncal heart defects by target sequencing. Hum Genomics. 2018;12(1):44. doi:10.1186/s40246-018-0176-0

199. Lappas M. Runt-related transcription factor 1 (RUNX1) deficiency attenuates inflammation-induced pro-inflammatory and pro-labour mediators in myometrium. Mol Cell Endocrinol. 2018;473:61-71. doi:10.1016/j.mce.2018.01.003

200. Liu R, Wei C, Ma Q, Wang W. Hippo-YAP1 signaling pathway and severe preeclampsia (sPE) in the Chinese population. Pregnancy Hypertens. 2020;19:1-10. doi:10.1016/j.preghy.2019.11.002

\section{Tables}

Table 1 The sequences of primers for quantitative RT-PCR

\begin{tabular}{ccc}
\hline Genes & Forward Primers & Reverse Primers \\
\hline HSP90AA1 & AGGAGGTTGAGACGTTCGC & AGAGTTCGATCTTGTTTGTTCGG \\
EGFR & AGGCACGAGTAACAAGCTCAC & ATGAGGACATAACCAGCCACC \\
RPS13 & TCCCAGTCGGCTTTACCCTAT & CAGGATTACACCGATCTGTGAAG \\
RBX1 & TTGTGGTTGATAACTGTGCCAT & GACGCCTGGTTAGCTTGACAT \\
PAK1 & CAGCCCCTCCGATGAGAAATA & CAAAACCGACATGAATTGTGTGT \\
FYN & ATGGGCTGTGTGCAATGTAAG & GAAGCTGGGGTAGTGCTGAG \\
ABL1 & AAGCCGCTCGTTGGAACTC & AGACCCGGAGCTTTTCACCT \\
SMAD3 & TGGACGCAGGTTCTCCAAAC & CCGGCTCGCAGTAGGTAAC \\
STAT3 & CAGCAGCTTGACACACGGTA & AAACACCAAAGTGGCATGTGA \\
PRKCA & GTCCACAAGAGGTGCCATGAA & AAGGTGGGGCTTCCGTAAGT \\
\hline
\end{tabular}

Table 2 The statistical metrics for key differentially expressed genes (DEGs)

\begin{tabular}{|c|c|c|c|c|c|c|c|}
\hline IlluminaID & GeneSymbol & $\log \mathrm{FC}$ & pValue & adj.P.Val & tvalue & Regulation & GeneName \\
\hline ILMN_3246433 & RNY5 & 1.462757 & $5.68 \mathrm{E}-06$ & 0.002906 & 4.775349 & Up & RNA, Ro60-associated Y5 \\
\hline ILMN_1668035 & $\mathrm{CRH}$ & 1.29002 & 0.001459 & 0.029715 & 3.266769 & Up & corticotropin releasing hormone \\
\hline ILMN_1716238 & PSG6 & 1.284052 & 0.00171 & 0.032189 & 3.217109 & Up & $\begin{array}{l}\text { pregnancy specific beta-1-glycoprotein } 6 \\
\text { pregnancy specific beta-1-glycoprotein } 7\end{array}$ \\
\hline ILMN_1772768 & PSG7 & 1.257768 & 0.001767 & 0.032784 & 3.206816 & Up & (gene/pseudogene) \\
\hline ILMN_2413473 & GH2 & 1.248351 & 0.002276 & 0.037103 & 3.126124 & Up & growth hormone 2 \\
\hline ILMN_1801776 & PSG9 & 1.204077 & 0.002468 & 0.038662 & 3.100092 & Up & pregnancy specific beta-1-glycoprotein 9 \\
\hline ILMN_1798000 & PSG1 & 1.147959 & 0.000469 & 0.017456 & 3.608336 & Up & pregnancy specific beta-1-glycoprotein 1 \\
\hline
\end{tabular}




\begin{tabular}{|c|c|c|c|c|c|c|c|}
\hline ILMN_1728734 & PSG5 & 1.143624 & 0.000969 & 0.024168 & 3.392528 & Up & $\begin{array}{l}\text { pregnancy specific beta-1-glycoprotein } 5 \\
\text { cytochrome P450 family } 19 \text { subfamily A }\end{array}$ \\
\hline ILMN_2387860 & CYP19A1 & 1.130568 & 0.00132 & 0.028092 & 3.297762 & Up & member 1 \\
\hline ILMN_1764483 & PSG2 & 1.123521 & 0.003218 & 0.044644 & 3.013539 & Up & pregnancy specific beta-1-glycoprotein 2 \\
\hline ILMN_1706911 & PSG11 & 1.115865 & 0.002642 & 0.040078 & 3.07808 & Up & pregnancy specific beta-1-glycoprotein 11 \\
\hline ILMN_1765187 & LHB & 1.086528 & 0.002327 & 0.037529 & 3.118995 & Up & luteinizing hormone subunit beta \\
\hline ILMN_1693397 & PSG4 & 1.079921 & 0.002644 & 0.040091 & 3.077764 & Up & pregnancy specific beta-1-glycoprotein 4 \\
\hline ILMN_1785393 & ADAM12 & 1.058143 & 0.003796 & 0.048669 & 2.958837 & Up & ADAM metallopeptidase domain 12 \\
\hline ILMN_1749078 & TIMP2 & 1.029031 & 0.001077 & 0.025325 & 3.360515 & Up & TIMP metallopeptidase inhibitor 2 \\
\hline ILMN_2406299 & SEMA3B & 1.019814 & 0.001424 & 0.029234 & 3.274226 & Up & semaphorin 3B \\
\hline ILMN_1691937 & $\mathrm{CSH} 2$ & 0.93195 & 0.003208 & 0.044568 & 3.014577 & Up & chorionic somatomammotropin hormone 2 \\
\hline ILMN_2044645 & CGB1 & 0.914238 & 0.003818 & 0.048801 & 2.956891 & Up & chorionic gonadotropin subunit beta 1 \\
\hline ILMN_2083578 & CGB7 & 0.902725 & 0.001095 & 0.025576 & 3.355412 & Up & chorionic gonadotropin subunit beta 7 \\
\hline ILMN_1754207 & PLAC1 & 0.846799 & 0.003832 & 0.048867 & 2.955674 & Up & placenta enriched 1 \\
\hline ILMN_1698318 & LGALS14 & 0.831948 & 0.001715 & 0.032189 & 3.216166 & Up & galectin 14 \\
\hline ILMN_2068104 & TFPI2 & 0.817524 & 0.003376 & 0.04562 & 2.997767 & Up & tissue factor pathway inhibitor 2 \\
\hline ILMN_2316236 & HOPX & 0.817388 & 0.000335 & 0.014808 & 3.70535 & Up & $\begin{array}{l}\text { HOP homeobox } \\
\text { major facilitator superfamily domain containing }\end{array}$ \\
\hline ILMN_1789638 & MFSD2A & 0.815456 & 0.002488 & 0.038799 & 3.097506 & Up & $2 \mathrm{~A}$ \\
\hline ILMN_1786908 & $\begin{array}{l}\text { KRTAP26-1 } \\
\text { LOC10050635 }\end{array}$ & 0.796216 & 0.00037 & 0.01533 & 3.677008 & Up & keratin associated protein $26-1$ \\
\hline ILMN_1659597 & 8 & 0.792699 & 0.000395 & 0.015895 & 3.658029 & Up & $\begin{array}{l}\text { uncharacterized LOC100506358 } \\
\text { endogenous retrovirus group } 3 \text { member } 1 \text {, }\end{array}$ \\
\hline ILMN_2118663 & ERV3-1 & 0.791098 & 0.001056 & 0.025169 & 3.366462 & Up & envelope \\
\hline ILMN_1712066 & EXPH5 & 0.790876 & 0.000584 & 0.01904 & 3.543961 & Up & exophilin 5 \\
\hline ILMN_1674696 & OLAH & 0.774415 & 0.00023 & 0.012505 & 3.811374 & Up & $\begin{array}{l}\text { oleoyl-ACP hydrolase } \\
\text { serine palmitoyltransferase long chain base }\end{array}$ \\
\hline ILMN_2233454 & SPTLC3 & 0.771167 & 0.000748 & 0.021335 & 3.470437 & Up & subunit 3 \\
\hline ILMN_1693530 & PSG3 & 0.760751 & 0.002195 & 0.036289 & 3.137778 & Up & pregnancy specific beta-1-glycoprotein 3 \\
\hline ILMN_1784824 & LINC01118 & 0.760468 & 0.001118 & 0.025812 & 3.349058 & Up & long intergenic non-protein coding RNA 1118 \\
\hline ILMN_1813350 & HSD11B2 & 0.758705 & 0.002101 & 0.035634 & 3.151814 & Up & hydroxysteroid 11-beta dehydrogenase 2 \\
\hline ILMN_2352921 & BPGM & 0.755678 & 0.000432 & 0.016748 & 3.631747 & Up & $\begin{array}{c}\text { bisphosphoglyceratemutase } \\
\text { phytanoyl-CoA 2-hydroxylase interacting }\end{array}$ \\
\hline ILMN_1678710 & PHYHIPL & 0.750771 & 0.000149 & 0.010164 & 3.932405 & Up & protein like \\
\hline ILMN_1794842 & LGALS13 & 0.737107 & 0.002229 & 0.036621 & 3.132873 & Up & galectin 13 \\
\hline ILMN_2188862 & GDF15 & 0.733888 & 0.003343 & 0.045512 & 3.000989 & Up & growth differentiation factor 15 \\
\hline ILMN_1702858 & ADHFE1 & 0.733838 & 0.000566 & 0.018799 & 3.553236 & Up & alcohol dehydrogenase iron containing 1 \\
\hline ILMN_2187746 & EMX2 & 0.724034 & 0.002408 & 0.038098 & 3.108039 & Up & $\begin{array}{l}\text { empty spiracles homeobox } 2 \\
\text { hydroxy-delta-5-steroid dehydrogenase, } 3 \text { beta- }\end{array}$ \\
\hline ILMN_1780693 & HSD3B1 & 0.713165 & 0.003003 & 0.043117 & 3.03634 & Up & and steroid delta-isomerase 1 \\
\hline ILMN_1814737 & LNPEP & 0.699558 & 0.001327 & 0.028154 & 3.296246 & Up & leucyl and cystinylaminopeptidase \\
\hline ILMN_1807277 & IFI30 & 0.696224 & 0.000433 & 0.01676 & 3.631088 & Up & IFI30 lysosomalthiolreductase \\
\hline ILMN_1756443 & INHA & 0.693534 & 0.000602 & 0.019237 & 3.535224 & Up & inhibin subunit alpha \\
\hline ILMN_1748090 & SLC2A11 & 0.691618 & 0.000104 & 0.008561 & 4.029682 & Up & solute carrier family 2 member 11 \\
\hline ILMN_1774287 & CFB & 0.689441 & 0.002619 & 0.039846 & 3.080829 & Up & complement factor B \\
\hline ILMN_1768662 & UCK2 & 0.666106 & 0.00056 & 0.018724 & 3.556095 & Up & uridine-cytidine kinase 2 \\
\hline ILMN_1720540 & INSL4 & 0.662317 & 0.001009 & 0.024621 & 3.380194 & Up & $\begin{array}{l}\text { insulin like } 4 \\
\text { tubulin polymerization promoting protein }\end{array}$ \\
\hline ILMN_1797744 & ТРPР3 & 0.660409 & 0.000586 & 0.019062 & 3.543117 & Up & family member 3 \\
\hline ILMN_1680139 & MAFF & 0.655013 & 0.001413 & 0.02907 & 3.276627 & Up & MAF bZIP transcription factor $F$ \\
\hline
\end{tabular}




\begin{tabular}{|c|c|c|c|c|c|c|c|}
\hline ILMN_2368188 & TRPV6 & 0.647442 & 0.001158 & 0.02618 & 3.338062 & $\mathrm{Up}$ & $\begin{array}{l}\text { transient receptor potential cation channel } \\
\text { subfamily V member } 6\end{array}$ \\
\hline ILMN_1740466 & TENT5A & 0.645318 & 0.000443 & 0.016957 & 3.624672 & $\mathrm{Up}$ & terminal nucleotidyltransferase $5 \mathrm{~A}$ \\
\hline ILMN_1800412 & BMP1 & 0.634772 & 0.000459 & 0.017315 & 3.614562 & $\mathrm{Up}$ & bone morphogenetic protein 1 \\
\hline ILMN_1727633 & NECTIN3 & 0.633198 & 0.002322 & 0.037503 & 3.11981 & $\mathrm{Up}$ & $\begin{array}{l}\text { nectin cell adhesion molecule } 3 \\
\text { protein phosphatase } 1 \text { regulatory inhibitor }\end{array}$ \\
\hline ILMN_1664855 & PPP1R14C & 0.629794 & 0.001066 & 0.025246 & 3.363473 & $\mathrm{Up}$ & subunit $14 \mathrm{C}$ \\
\hline ILMN_1695562 & ZNF471 & 0.623497 & 0.000993 & 0.024402 & 3.38509 & $\mathrm{Up}$ & zinc finger protein 471 \\
\hline ILMN_1714586 & VGLL3 & 0.618471 & 0.001854 & 0.033507 & 3.191522 & $\mathrm{Up}$ & vestigial like family member 3 \\
\hline ILMN_1744949 & RHOBTB3 & 0.61326 & 0.001612 & 0.031272 & 3.235567 & $\mathrm{Up}$ & Rho related BTB domain containing 3 \\
\hline ILMN_1703284 & SPIRE2 & 0.612933 & 0.00328 & 0.045007 & 3.007246 & $\mathrm{Up}$ & spire type actin nucleation factor 2 \\
\hline ILMN_1704376 & GLDN & 0.605249 & 0.002329 & 0.037531 & 3.118817 & $\mathrm{Up}$ & gliomedin \\
\hline ILMN_2415421 & SLC30A2 & 0.602925 & 0.002569 & 0.039356 & 3.087159 & $\mathrm{Up}$ & solute carrier family 30 member 2 \\
\hline ILMN_1757406 & $\mathrm{H} 1-2$ & 0.598625 & 0.001243 & 0.027166 & 3.316284 & $\mathrm{Up}$ & H1.2 linker histone, cluster member \\
\hline ILMN_1651496 & $\mathrm{H} 2 \mathrm{BC} 5$ & 0.597413 & 0.000105 & 0.008597 & 4.027633 & $\mathrm{Up}$ & $\begin{array}{l}\text { H2B clustered histone } 5 \\
\text { ectonucleoside triphosphate }\end{array}$ \\
\hline ILMN_1773125 & ENTPD1 & 0.596924 & 0.003282 & 0.045007 & 3.007041 & $\mathrm{Up}$ & diphosphohydrolase 1 \\
\hline ILMN_1790228 & FURIN & 0.595716 & 0.001344 & 0.028402 & 3.292157 & $\mathrm{Up}$ & furin, paired basic amino acid cleaving enzyme \\
\hline ILMN_1741143 & TXK & 0.593669 & 0.001359 & 0.028533 & 3.288903 & $\mathrm{Up}$ & TXK tyrosine kinase \\
\hline ILMN_1787750 & CD200 & 0.592992 & 0.001168 & 0.02622 & 3.335461 & $\mathrm{Up}$ & CD200 molecule \\
\hline ILMN_1795106 & PSG8 & 0.59239 & 0.002853 & 0.041916 & 3.053083 & $\mathrm{Up}$ & pregnancy specific beta-1-glycoprotein 8 \\
\hline ILMN_1672908 & TWIST1 & 0.585791 & 0.002193 & 0.036269 & 3.138064 & $\mathrm{Up}$ & $\begin{array}{l}\text { twist family bHLH transcription factor } 1 \\
\text { Cbp/p300 interacting transactivator with }\end{array}$ \\
\hline ILMN_1787691 & CITED4 & 0.583851 & 0.000456 & 0.017275 & 3.616082 & $\mathrm{Up}$ & Glu/Asp rich carboxy-terminal domain 4 \\
\hline ILMN_1740917 & SCNN1B & 0.580064 & 0.00208 & 0.035516 & 3.155039 & $\mathrm{Up}$ & sodium channel epithelial 1 beta subunit \\
\hline ILMN_1681248 & $\mathrm{TCHH}$ & 0.579544 & 0.000868 & 0.023007 & 3.42568 & $\mathrm{Up}$ & trichohyalin \\
\hline ILMN_1713397 & NCCRP1 & 0.577054 & 0.001607 & 0.031251 & 3.236641 & Up & NCCRP1, F-box associated domain containing \\
\hline ILMN_1771019 & MTMR4 & 0.575772 & 0.000998 & 0.024462 & 3.383725 & $\mathrm{Up}$ & myotubularin related protein 4 \\
\hline ILMN_1792689 & H2AC6 & 0.572844 & 0.000198 & 0.011571 & 3.853384 & $\mathrm{Up}$ & H2A clustered histone 6 \\
\hline ILMN_1732071 & $\mathrm{H} 2 \mathrm{BC} 21$ & 0.571255 & 0.000494 & 0.01788 & 3.593188 & $\mathrm{Up}$ & H2B clustered histone 21 \\
\hline ILMN_1777934 & MORN3 & 0.570881 & 0.000392 & 0.015793 & 3.660351 & $\mathrm{Up}$ & MORN repeat containing 3 \\
\hline ILMN_1754126 & SH2D5 & 0.567064 & 0.000548 & 0.018452 & 3.562897 & $\mathrm{Up}$ & $\begin{array}{l}\text { SH2 domain containing } 5 \\
\text { cytochrome P450 family } 11 \text { subfamily A }\end{array}$ \\
\hline ILMN_1768820 & CYP11A1 & 0.562921 & 0.002281 & 0.037107 & 3.125417 & $\mathrm{Up}$ & member 1 \\
\hline ILMN_1721842 & RYBP & 0.560609 & 0.001133 & 0.026002 & 3.344898 & $\mathrm{Up}$ & RING1 and YY1 binding protein \\
\hline ILMN_2323172 & CSF3R & 0.55608 & 0.002173 & 0.03615 & 3.140995 & $\mathrm{Up}$ & colony stimulating factor 3 receptor \\
\hline ILMN_1693789 & ALPP & 0.554751 & 0.003332 & 0.045427 & 3.002056 & $\mathrm{Up}$ & alkaline phosphatase, placental \\
\hline ILMN_2129015 & AFF1 & 0.5529 & 0.003097 & 0.043799 & 3.026214 & $\mathrm{Up}$ & AF4/FMR2 family member 1 \\
\hline ILMN_1807652 & STRA6 & 0.548925 & 0.001375 & 0.028697 & 3.285192 & $\mathrm{Up}$ & stimulated by retinoic acid 6 \\
\hline ILMN_1746517 & KYNU & 0.547309 & 0.002021 & 0.035003 & 3.164234 & $\mathrm{Up}$ & kynureninase \\
\hline ILMN_1793695 & ITIH5 & 0.543721 & 0.002744 & 0.041015 & 3.065788 & $\mathrm{Up}$ & inter-alpha-trypsin inhibitor heavy chain 5 \\
\hline ILMN_1814600 & DEPDC1B & 0.542445 & 0.001287 & 0.027725 & 3.305687 & $\mathrm{Up}$ & DEP domain containing 1B \\
\hline ILMN_1708340 & DAPK1 & 0.541376 & 0.003167 & 0.04426 & 3.018827 & $\mathrm{Up}$ & $\begin{array}{c}\text { death associated protein kinase } 1 \\
\text { ST3 beta-galactoside alpha-2,3-sialyltransferase }\end{array}$ \\
\hline ILMN_2204545 & ST3GAL4 & 0.537233 & 0.001733 & 0.032379 & 3.212881 & $\mathrm{Up}$ & 4 \\
\hline ILMN_1794239 & ODAPH & 0.533324 & 0.000498 & 0.017895 & 3.590399 & $\mathrm{Up}$ & $\begin{array}{l}\text { odontogenesis associated phosphoprotein } \\
\text { transforming acidic coiled-coil containing }\end{array}$ \\
\hline ILMN_2315780 & TACC2 & 0.532522 & 0.000106 & 0.00868 & 4.024113 & $\mathrm{Up}$ & protein 2 \\
\hline ILMN_2309446 & RBBP6 & 0.528104 & 0.000254 & 0.013135 & 3.783862 & $\mathrm{Up}$ & RB binding protein 6 , ubiquitin ligase \\
\hline
\end{tabular}




\begin{tabular}{|c|c|c|c|c|c|c|c|}
\hline ILMN_1791545 & KRT23 & 0.527971 & 0.000209 & 0.011919 & 3.838417 & Up & keratin 23 \\
\hline ILMN_1798458 & KAZN & 0.51384 & 0.001255 & 0.027297 & 3.313396 & Up & kazrin, periplakin interacting protein \\
\hline ILMN_1777683 & ADAMTSL4 & 0.513545 & 0.00031 & 0.014326 & 3.727088 & Up & ADAMTS like 4 \\
\hline ILMN_1811593 & NIPAL1 & 0.509377 & 0.000573 & 0.018927 & 3.549631 & Up & NIPA like domain containing 1 \\
\hline ILMN_3236821 & HSPB1 & 0.507177 & 0.000829 & 0.022503 & 3.439718 & Up & heat shock protein family B (small) member 1 \\
\hline ILMN_1774229 & SLC7A4 & 0.504867 & 0.003047 & 0.043409 & 3.031496 & Up & solute carrier family 7 member 4 \\
\hline ILMN_1795838 & C4orf19 & 0.503581 & 0.000615 & 0.019397 & 3.528742 & Up & chromosome 4 open reading frame 19 \\
\hline ILMN_1689004 & TNFRSF12A & 0.50273 & 0.000813 & 0.022284 & 3.44546 & Up & TNF receptor superfamily member $12 \mathrm{~A}$ \\
\hline ILMN_1702105 & EFS & 0.502312 & 0.001688 & 0.032021 & 3.221088 & Up & embryonal Fyn-associated substrate \\
\hline ILMN_1725831 & TINCR & 0.502082 & 0.001143 & 0.026058 & 3.342141 & Up & $\begin{array}{l}\text { TINCR ubiquitin domain containing } \\
\text { RHO family interacting cell polarization }\end{array}$ \\
\hline ILMN_1726597 & RIPOR2 & 0.501684 & 0.000791 & 0.022033 & 3.453621 & Up & regulator 2 \\
\hline ILMN_1746618 & PAQR7 & 0.498553 & 0.000293 & 0.014028 & 3.743357 & Up & progestin and adipoQ receptor family member 7 \\
\hline ILMN_2351638 & BEX4 & 0.49812 & $1.22 \mathrm{E}-05$ & 0.003404 & 4.586051 & Up & brain expressed $\mathrm{X}$-linked 4 \\
\hline ILMN_1762207 & SGSM1 & 0.495004 & 0.000544 & 0.018404 & 3.565008 & Up & $\begin{array}{l}\text { small } \mathrm{G} \text { protein signaling modulator } 1 \\
\text { GULP PTB domain containing engulfment }\end{array}$ \\
\hline ILMN_1802690 & GULP1 & 0.492328 & 0.002712 & 0.040738 & 3.069508 & Up & adaptor 1 \\
\hline ILMN_1679041 & SLC3A2 & 0.486676 & 0.001058 & 0.025186 & 3.365946 & Up & solute carrier family 3 member 2 \\
\hline ILMN_1728677 & CREB5 & 0.486008 & 0.000136 & 0.009772 & 3.957019 & Up & cAMP responsive element binding protein 5 \\
\hline ILMN_2390609 & ANK3 & 0.481205 & 0.001627 & 0.031404 & 3.232619 & Up & $\begin{array}{l}\text { ankyrin } 3 \\
\text { coiled-coil-helix-coiled-coil-helix domain }\end{array}$ \\
\hline ILMN_1740170 & CHCHD10 & 0.479287 & 0.002374 & 0.03792 & 3.11261 & Up & containing 10 \\
\hline ILMN_1813139 & ANKDD1A & 0.477831 & 0.000338 & 0.014847 & 3.702751 & Up & $\begin{array}{l}\text { ankyrin repeat and death domain containing } 1 \mathrm{~A} \\
\text { STT3 oligosaccharyltransferase complex }\end{array}$ \\
\hline ILMN_2194448 & STT3B & 0.477537 & 0.00228 & 0.037103 & 3.125635 & Up & $\begin{array}{c}\text { catalytic subunit B } \\
\text { endogenous retrovirus group W member 1, }\end{array}$ \\
\hline ILMN_1684034 & STAT5B & 0.466134 & 0.000495 & 0.01788 & 3.59265 & Up & signal transducer and activator of transcription \\
\hline ILMN_1796423 & CLIC3 & 0.465597 & 0.001265 & 0.027404 & 3.31097 & Up & chloride intracellular channel 3 \\
\hline ILMN_3280402 & GLRX & 0.464843 & 0.000542 & 0.018404 & 3.56612 & Up & glutaredoxin \\
\hline ILMN_1753931 & CDO1 & 0.464443 & 0.000182 & 0.011037 & 3.877815 & Up & cysteine dioxygenase type 1 \\
\hline ILMN_2065690 & GRAMD2B & 0.464402 & 0.000499 & 0.017901 & 3.589918 & Up & GRAM domain containing $2 \mathrm{~B}$ \\
\hline ILMN_1752510 & FAM13A & 0.463446 & 0.000335 & 0.014808 & 3.705566 & Up & family with sequence similarity 13 member A \\
\hline ILMN_2384857 & DHRS2 & 0.460744 & 0.001634 & 0.031474 & 3.23133 & Up & dehydrogenase/reductase 2 \\
\hline ILMN_1720771 & STX11 & 0.459749 & 0.002149 & 0.035892 & 3.144568 & Up & syntaxin 11 \\
\hline ILMN_1807563 & FKBP2 & 0.457573 & 0.000724 & 0.02097 & 3.480237 & Up & FKBP prolylisomerase 2 \\
\hline ILMN_1669557 & CRYBG2 & 0.4569 & 0.001328 & 0.028154 & 3.296056 & Up & crystallin beta-gamma domain containing 2 \\
\hline ILMN_1699206 & FHDC1 & 0.455751 & 0.00209 & 0.035562 & 3.153528 & Up & FH2 domain containing 1 \\
\hline ILMN_1806149 & C16orf74 & 0.455006 & 0.000426 & 0.016582 & 3.636053 & Up & chromosome 16 open reading frame 74 \\
\hline ILMN_1751120 & $\mathrm{H} 4 \mathrm{C} 8$ & 0.45076 & 0.000764 & 0.021605 & 3.464112 & Up & H4 clustered histone 8 \\
\hline ILMN_1740604 & RAB11FIP5 & 0.450629 & 0.003974 & 0.049778 & 2.943476 & Up & RAB11 family interacting protein 5 \\
\hline ILMN_3195497 & ADIRF-AS1 & 0.448015 & 0.002142 & 0.035854 & 3.145598 & Up & ADIRF antisense RNA 1 \\
\hline ILMN_1813625 & TRIM25 & 0.445493 & 0.000114 & 0.00893 & 4.005574 & Up & tripartite motif containing 25 \\
\hline ILMN_1753515 & SRR & 0.44366 & 0.003251 & 0.044884 & 3.010168 & Up & serine racemase \\
\hline ILMN_1772627 & NSG1 & 0.441643 & 0.001427 & 0.029273 & 3.273602 & Up & neuronal vesicle trafficking associated 1 \\
\hline ILMN_2364700 & ENSA & 0.441237 & $1.88 \mathrm{E}-05$ & 0.004187 & 4.477906 & Up & endosulfine alpha \\
\hline ILMN_1674243 & TFRC & 0.43767 & 0.003549 & 0.046989 & 2.981226 & Up & transferrin receptor \\
\hline
\end{tabular}




\begin{tabular}{|c|c|c|c|c|c|c|c|}
\hline ILMN_1779448 & EFHD1 & 0.435614 & 0.003381 & 0.045635 & 2.997287 & Up & EF-hand domain family member D1 \\
\hline ILMN_1798975 & EGFR & 0.434921 & 0.002718 & 0.040787 & 3.068785 & Up & epidermal growth factor receptor \\
\hline ILMN_1802053 & ZNF91 & 0.433844 & 0.000914 & 0.023507 & 3.410338 & Up & zinc finger protein 91 \\
\hline ILMN_1797557 & PLEKHA6 & 0.43335 & 0.003538 & 0.046906 & 2.982198 & Up & pleckstrin homology domain containing A6 \\
\hline ILMN_1814333 & SERPINI1 & 0.433318 & 0.00355 & 0.046989 & 2.981082 & Up & serpin family I member 1 \\
\hline ILMN_1683211 & NCAN & 0.430909 & 0.002311 & 0.037392 & 3.121301 & Up & neurocan \\
\hline ILMN_2142353 & GRTP1 & 0.430742 & 0.001078 & 0.025332 & 3.360135 & Up & growth hormone regulated TBC protein 1 \\
\hline ILMN_1809477 & CARHSP1 & 0.428795 & 0.001041 & 0.024977 & 3.370793 & Up & calcium regulated heat stable protein 1 \\
\hline ILMN_1767365 & PAK1 & 0.427899 & 0.000143 & 0.009932 & 3.94428 & Up & $\begin{array}{c}\text { p21 (RAC1) activated kinase } 1 \\
\text { CAP-Gly domain containing linker protein }\end{array}$ \\
\hline ILMN_1759792 & CLIP4 & 0.427572 & 0.000478 & 0.017642 & 3.60267 & Up & family member 4 \\
\hline ILMN_2143685 & CLDN7 & 0.426872 & 0.000634 & 0.019679 & 3.519853 & Up & claudin 7 \\
\hline ILMN_2074860 & RN7SK & 0.425278 & 0.000506 & 0.017919 & 3.586106 & Up & $\begin{array}{l}\text { RNA component of } 7 \mathrm{SK} \text { nuclear } \\
\text { ribonucleoprotein }\end{array}$ \\
\hline ILMN_1742538 & PCDHGC4 & 0.422624 & 0.00088 & 0.023184 & 3.421715 & Up & protocadherin gamma subfamily C, 4 \\
\hline ILMN_1689817 & LCOR & 0.419011 & 0.001391 & 0.028854 & 3.281687 & Up & ligand dependent nuclear receptor corepressor \\
\hline ILMN_1667994 & AMD1 & 0.418735 & 0.00061 & 0.019374 & 3.531034 & Up & $\begin{array}{l}\text { adenosylmethionine decarboxylase } 1 \\
\text { acyl-CoA synthetase long chain family member }\end{array}$ \\
\hline ILMN_1683598 & ACSL4 & 0.416616 & 0.003954 & 0.04961 & 2.945175 & Up & 4 \\
\hline ILMN_1796206 & KMT2C & 0.415266 & $8.27 \mathrm{E}-05$ & 0.007525 & 4.092148 & Up & $\begin{array}{c}\text { lysine methyltransferase 2C } \\
\text { glucosamine (UDP-N-acetyl)-2-epimerase/N- }\end{array}$ \\
\hline ILMN_1729417 & GNE & 0.413507 & 0.001169 & 0.02622 & 3.335407 & Up & acetylmannosamine kinase \\
\hline ILMN_1778956 & STS & 0.411932 & 0.000347 & 0.014977 & 3.695049 & Up & steroid sulfatase \\
\hline ILMN_2405254 & GRB7 & 0.408773 & 0.00026 & 0.013186 & 3.777315 & Up & growth factor receptor bound protein 7 \\
\hline ILMN_1813314 & $\mathrm{H} 2 \mathrm{BC} 12$ & 0.408761 & 0.002651 & 0.04015 & 3.076962 & Up & H2B clustered histone 12 \\
\hline ILMN_2346339 & FOLR1 & 0.407865 & 0.000266 & 0.013333 & 3.771078 & Up & $\begin{array}{l}\text { folate receptor alpha } \\
\text { glycosylphosphatidylinositol anchor attachment }\end{array}$ \\
\hline ILMN_1747112 & GPAA1 & 0.407772 & $1.5 \mathrm{E}-05$ & 0.003692 & 4.534163 & Up & 1 \\
\hline ILMN_1736863 & TMEM140 & 0.40612 & 0.000597 & 0.019237 & 3.537542 & Up & $\begin{array}{l}\text { transmembrane protein } 140 \\
\text { pregnancy specific beta-1-glycoprotein } 10,\end{array}$ \\
\hline ILMN_3226388 & PSG10P & 0.399644 & 0.00336 & 0.045553 & 2.999338 & Up & pseudogene \\
\hline ILMN_1769092 & EVA1B & 0.398688 & 0.002925 & 0.042546 & 3.044952 & Up & eva-1 homolog B \\
\hline ILMN_1654322 & ATP1B3 & 0.398471 & 0.00148 & 0.029861 & 3.262353 & Up & ATPase $\mathrm{Na}+/ \mathrm{K}+$ transporting subunit beta 3 \\
\hline ILMN_1699674 & ZNF703 & 0.397878 & 0.003462 & 0.046339 & 2.989443 & Up & $\begin{array}{l}\text { zinc finger protein } 703 \\
\text { gamma-aminobutyric acid type A receptor }\end{array}$ \\
\hline ILMN_2159730 & GABRB1 & 0.396679 & 0.000663 & 0.020103 & 3.506538 & Up & betal subunit \\
\hline ILMN_2342437 & KLHL5 & 0.395369 & 0.003031 & 0.043318 & 3.033257 & Up & kelch like family member 5 \\
\hline ILMN_1704472 & EID2 & 0.394584 & 8.47E-06 & 0.00295 & 4.677314 & Up & EP300 interacting inhibitor of differentiation 2 \\
\hline ILMN_2374865 & ATF3 & 0.394537 & 0.001939 & 0.034245 & 3.177337 & Up & activating transcription factor 3 \\
\hline ILMN_1652540 & RELL2 & 0.39244 & 0.00081 & 0.022284 & 3.446717 & Up & RELT like 2 \\
\hline ILMN_1697642 & ВСАР29 & 0.391558 & 0.000201 & 0.011654 & 3.849685 & Up & B cell receptor associated protein 29 \\
\hline ILMN_2382974 & $\mathrm{CCDC} 7$ & 0.391544 & 0.000891 & 0.023304 & 3.4178 & Up & coiled-coil domain containing 7 \\
\hline ILMN_1742260 & ITPRID2 & 0.39091 & 0.000176 & 0.010925 & 3.886377 & Up & ITPR interacting domain containing 2 \\
\hline ILMN_2060145 & GRHL2 & 0.389706 & 0.000397 & 0.015954 & 3.656341 & Up & grainyhead like transcription factor 2 \\
\hline ILMN_2195821 & CREBRF & 0.389024 & 0.000261 & 0.013186 & 3.77657 & Up & CREB3 regulatory factor \\
\hline ILMN_1746676 & CLDN8 & 0.388757 & 0.002765 & 0.041192 & 3.063276 & Up & claudin 8 \\
\hline ILMN_1700583 & ZNF750 & 0.388452 & 0.000505 & 0.017918 & 3.586783 & Up & zinc finger protein 750 \\
\hline ILMN_1655913 & NUCB2 & 0.386679 & 0.002616 & 0.039837 & 3.081247 & Up & nucleobindin 2 \\
\hline ILMN_1701393 & TBX3 & 0.381209 & $1.9 \mathrm{E}-05$ & 0.004198 & 4.474884 & Up & T-box transcription factor 3 \\
\hline
\end{tabular}




\begin{tabular}{|c|c|c|c|c|c|c|c|}
\hline ILMN_1769201 & ELF3 & 0.380808 & 0.002808 & 0.041529 & 3.058207 & $\mathrm{Up}$ & E74 like ETS transcription factor 3 \\
\hline ILMN_1791280 & HSPB8 & 0.380526 & 0.002023 & 0.03504 & 3.163783 & $\mathrm{Up}$ & heat shock protein family B (small) member 8 \\
\hline ILMN_2149292 & TMEM40 & 0.378498 & 0.000676 & 0.020287 & 3.500728 & Up & transmembrane protein 40 \\
\hline ILMN_1707088 & DENND2D & 0.37794 & 7.09E-05 & 0.007061 & 4.133296 & $\mathrm{Up}$ & $\begin{array}{c}\text { DENN domain containing 2D } \\
\text { pleckstrin homology like domain family B }\end{array}$ \\
\hline ILMN_2179778 & PHLDB2 & 0.377513 & 0.000242 & 0.012762 & 3.797837 & $\mathrm{Up}$ & member 2 \\
\hline ILMN_1801216 & S100P & 0.375994 & 0.00042 & 0.016421 & 3.640526 & $\mathrm{Up}$ & $\begin{array}{c}\text { S100 calcium binding protein } \mathrm{P} \\
\text { pleckstrin homology }\end{array}$ \\
\hline ILMN_1699254 & PLEKHH1 & 0.374597 & 0.000398 & 0.015954 & 3.656068 & Up & domain containing $\mathrm{H} 1$ \\
\hline ILMN_1710954 & FBXL19-AS1 & 0.37328 & 0.000271 & 0.013483 & 3.765506 & $\mathrm{Up}$ & FBXL19 antisense RNA 1 \\
\hline ILMN_2376502 & RHOBTB1 & 0.372696 & 0.001027 & 0.024813 & 3.374907 & $\mathrm{Up}$ & Rho related BTB domain containing 1 \\
\hline ILMN_1673455 & RASAL2 & 0.372204 & $6.16 \mathrm{E}-05$ & 0.006575 & 4.170741 & $\mathrm{Up}$ & $\begin{array}{c}\text { RAS protein activator like } 2 \\
\text { eva-1 homolog A, regulator of programmed cell }\end{array}$ \\
\hline ILMN_3194638 & EVA1A & 0.371837 & 0.001826 & 0.033257 & 3.196396 & $\mathrm{Up}$ & death \\
\hline ILMN_1710284 & HES 1 & 0.370834 & 0.000842 & 0.022673 & 3.435074 & $\mathrm{Up}$ & hes family bHLH transcription factor 1 \\
\hline ILMN_2064655 & CXorf40A & 0.369875 & $3.68 \mathrm{E}-05$ & 0.005267 & 4.305465 & $\mathrm{Up}$ & chromosome $\mathrm{X}$ open reading frame $40 \mathrm{~A}$ \\
\hline ILMN_2373566 & PJA1 & 0.365283 & 0.001767 & 0.032784 & 3.206709 & $\mathrm{Up}$ & praja ring finger ubiquitin ligase 1 \\
\hline ILMN_1779648 & $\mathrm{H} 2 \mathrm{AW}$ & 0.365117 & 0.002673 & 0.040354 & 3.074252 & $\mathrm{Up}$ & H2A.W histone \\
\hline ILMN_2333107 & TLE5 & 0.363987 & 0.003586 & 0.047223 & 2.977803 & $\mathrm{Up}$ & $\begin{array}{l}\text { TLE family member } 5 \text {, transcriptional } \\
\text { modulator }\end{array}$ \\
\hline ILMN_1722025 & CPEB4 & 0.363264 & 0.000601 & 0.019237 & 3.535255 & $\mathrm{Up}$ & protein 4 \\
\hline ILMN_1670263 & CNST & 0.362857 & 0.001654 & 0.031635 & 3.227556 & $\mathrm{Up}$ & consortin, connexin sorting protein \\
\hline ILMN_2214678 & MXD1 & 0.36052 & 0.003377 & 0.04562 & 2.997692 & $\mathrm{Up}$ & $\begin{array}{l}\text { MAX dimerization protein } 1 \\
\text { gamma-aminobutyric acid type } \mathrm{A} \text { receptor }\end{array}$ \\
\hline ILMN_2324202 & GABRE & 0.359786 & 0.001796 & 0.032966 & 3.20158 & $\mathrm{Up}$ & epsilon subunit \\
\hline ILMN_2049727 & OSER1 & 0.358697 & 0.000322 & 0.014545 & 3.716924 & $\mathrm{Up}$ & oxidative stress responsive serine rich 1 \\
\hline ILMN_1704377 & USP27X & 0.35826 & 0.00113 & 0.025976 & 3.34568 & $\mathrm{Up}$ & ubiquitin specific peptidase $27 \mathrm{X}$-linked \\
\hline ILMN_3233388 & RELL1 & 0.357964 & 0.002177 & 0.036172 & 3.1404 & $\mathrm{Up}$ & RELT like 1 \\
\hline ILMN_1670878 & YTHDC1 & 0.357534 & $1.29 \mathrm{E}-06$ & 0.001955 & 5.128971 & $\mathrm{Up}$ & YTH domain containing 1 \\
\hline ILMN_1815445 & IDS & 0.356888 & 0.002505 & 0.038937 & 3.095289 & $\mathrm{Up}$ & iduronate 2-sulfatase \\
\hline ILMN_1775448 & PFN2 & 0.353131 & 0.000871 & 0.023045 & 3.424684 & $\mathrm{Up}$ & profilin 2 \\
\hline ILMN_1657423 & SPG21 & 0.353073 & 0.000213 & 0.011986 & 3.833747 & $\mathrm{Up}$ & $\begin{array}{l}\text { SPG21 abhydrolase domain containing, } \\
\text { maspardin }\end{array}$ \\
\hline ILMN_2162799 & AHR & 0.353025 & 0.002516 & 0.039016 & 3.093903 & $\mathrm{Up}$ & aryl hydrocarbon receptor \\
\hline ILMN_1698323 & PLEKHB2 & 0.352741 & 0.00209 & 0.035562 & 3.153476 & $\mathrm{Up}$ & pleckstrin homology domain containing B2 \\
\hline ILMN_1725718 & ZSCAN4 & 0.352414 & 0.000589 & 0.019114 & 3.541628 & $\mathrm{Up}$ & zinc finger and SCAN domain containing 4 \\
\hline ILMN_2414325 & TNFAIP8 & 0.351941 & 4.64E-05 & 0.005784 & 4.245233 & $\mathrm{Up}$ & TNF alpha induced protein 8 \\
\hline ILMN_1656291 & TSKS & 0.350101 & $3.27 \mathrm{E}-05$ & 0.005189 & 4.336503 & $\mathrm{Up}$ & testis specific serine kinase substrate \\
\hline ILMN_3245236 & FBRS & 0.349549 & 0.002921 & 0.042546 & 3.045346 & $\mathrm{Up}$ & fibrosin \\
\hline ILMN_3243972 & SNORA70B & 0.349376 & 0.00036 & 0.015127 & 3.684829 & $\mathrm{Up}$ & small nucleolar RNA, H/ACA box 70B \\
\hline ILMN_1687519 & SNAP23 & 0.349045 & 0.000691 & 0.020442 & 3.494035 & $\mathrm{Up}$ & synaptosome associated protein 23 \\
\hline ILMN_3307729 & CXXC5 & 0.347435 & 0.003855 & 0.04893 & 2.953691 & Up & CXXC finger protein 5 \\
\hline ILMN_2359601 & CAMK2G & 0.346831 & $1.67 \mathrm{E}-06$ & 0.001955 & 5.068099 & $\mathrm{Up}$ & $\begin{array}{l}\text { calcium/calmodulin dependent protein kinase II } \\
\text { gamma }\end{array}$ \\
\hline ILMN_2358541 & RBMS1 & 0.346578 & 0.001495 & 0.030009 & 3.259102 & $\mathrm{Up}$ & $\begin{array}{l}\text { RNA binding motif single stranded interacting } \\
\text { protein } 1\end{array}$ \\
\hline ILMN_1812262 & DDR1 & 0.345856 & 0.001274 & 0.027548 & 3.308776 & $\mathrm{Up}$ & discoidin domain receptor tyrosine kinase 1 \\
\hline ILMN_1655702 & ABHD5 & 0.34552 & 0.000199 & 0.011583 & 3.852742 & $\mathrm{Up}$ & abhydrolase domain containing 5 \\
\hline ILMN_1730294 & INO80C & 0.345306 & 0.000584 & 0.01904 & 3.543858 & $\mathrm{Up}$ & INO80 complex subunit $\mathrm{C}$ \\
\hline ILMN_1729095 & PDZD2 & 0.34383 & 0.000816 & 0.022314 & 3.444388 & $\mathrm{Up}$ & PDZ domain containing 2 \\
\hline
\end{tabular}




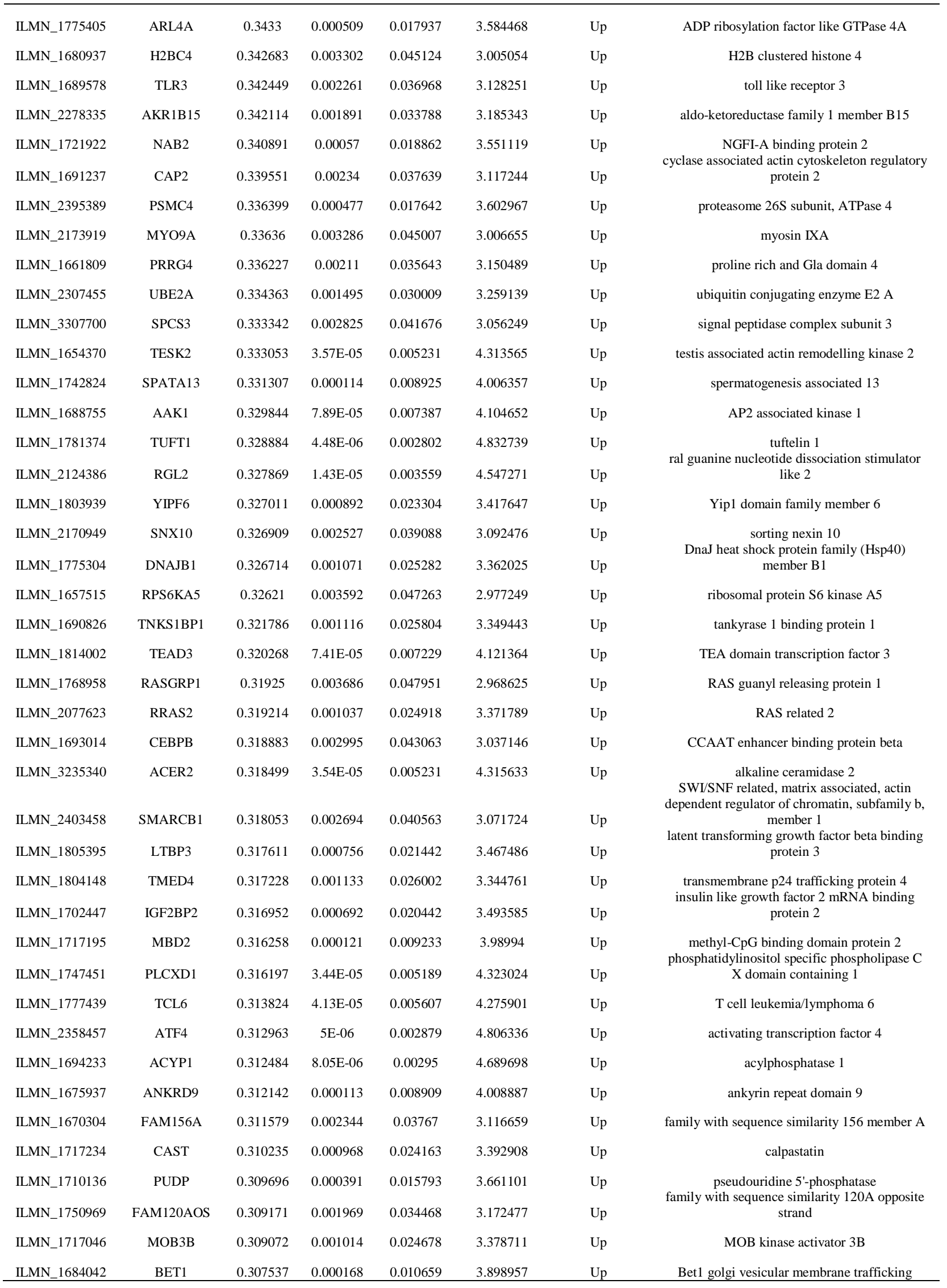




\begin{tabular}{|c|c|c|c|c|c|c|c|}
\hline & & & & & & & protein \\
\hline ILMN_1664303 & HTATIP2 & 0.306236 & 0.00063 & 0.019629 & 3.521367 & $\mathrm{Up}$ & HIV-1 Tat interactive protein 2 \\
\hline ILMN_3263225 & CRIM1-DT & 0.305254 & 0.000552 & 0.018547 & 3.560684 & $\mathrm{Up}$ & CRIM1 divergent transcript \\
\hline ILMN_1763127 & ACKR2 & 0.305224 & 0.001928 & 0.03416 & 3.179209 & $\mathrm{Up}$ & atypical chemokine receptor 2 \\
\hline ILMN_1708611 & RDX & 0.30478 & 0.001592 & 0.031099 & 3.239468 & $\mathrm{Up}$ & radixin \\
\hline ILMN_2190414 & ZNF83 & 0.304639 & 0.003774 & 0.048525 & 2.960719 & $\mathrm{Up}$ & zinc finger protein 83 \\
\hline ILMN_3184978 & ST8SIA6-AS1 & 0.304228 & $3.46 \mathrm{E}-05$ & 0.005189 & 4.321517 & $\mathrm{Up}$ & ST8SIA6 antisense RNA 1 \\
\hline ILMN_1746494 & FNTA & 0.303227 & $2.43 \mathrm{E}-05$ & 0.00477 & 4.412621 & $\mathrm{Up}$ & farnesyltransferase, CAAX box, alpha \\
\hline ILMN_3238854 & RGPD8 & 0.302737 & 0.000139 & 0.00984 & 3.950626 & $\mathrm{Up}$ & RANBP2 like and GRIP domain containing 8 \\
\hline ILMN_2322498 & RORA & 0.302665 & $5.91 \mathrm{E}-05$ & 0.006473 & 4.181545 & $\mathrm{Up}$ & RAR related orphan receptor A \\
\hline ILMN_1716988 & OPN3 & 0.300318 & 0.002185 & 0.036205 & 3.139321 & $\mathrm{Up}$ & $\begin{array}{c}\text { opsin } 3 \\
\text { signal peptidase complex subunit } 2 \text { pseudogene }\end{array}$ \\
\hline ILMN_1780382 & SPCS2P4 & 0.299459 & 0.003743 & 0.048256 & 2.963549 & $\mathrm{Up}$ & 4 \\
\hline ILMN_1782685 & DDB1 & 0.298269 & 0.003647 & 0.047663 & 2.972203 & $\mathrm{Up}$ & damage specific DNA binding protein 1 \\
\hline ILMN_1801020 & ADK & 0.298209 & 0.000201 & 0.011664 & 3.849125 & $\mathrm{Up}$ & adenosine kinase \\
\hline ILMN_1653793 & PDPK1 & 0.297954 & 0.002793 & 0.041395 & 3.059925 & $\mathrm{Up}$ & 3-phosphoinositide dependent protein kinase 1 \\
\hline ILMN_1805225 & LPCAT3 & 0.296395 & $6.38 \mathrm{E}-06$ & 0.00295 & 4.746876 & $\mathrm{Up}$ & lysophosphatidylcholineacyltransferase 3 \\
\hline ILMN_1741371 & PGAP6 & 0.296064 & 0.003279 & 0.045007 & 3.007377 & $\mathrm{Up}$ & $\begin{array}{l}\text { proteins } 6 \\
\text { cytochrome c oxidase copper chaperone }\end{array}$ \\
\hline ILMN_2187718 & COX17 & 0.295972 & 0.000244 & 0.01284 & 3.795442 & $\mathrm{Up}$ & COX17 \\
\hline ILMN_2263466 & ACADVL & 0.295932 & 0.000784 & 0.021918 & 3.456584 & Up & acyl-CoA dehydrogenase very long chain \\
\hline ILMN_1687947 & H2BC6 & 0.295728 & 0.000669 & 0.020173 & 3.503643 & $\mathrm{Up}$ & H2B clustered histone 6 \\
\hline ILMN_1807423 & $\begin{array}{l}\text { IGF2BP3 } \\
\text { STAG3L5P- } \\
\text { PVRIG2P- }\end{array}$ & 0.293802 & 0.000826 & 0.02247 & 3.440691 & Up & protein 3 \\
\hline ILMN_3204734 & PILRB & 0.293124 & 0.003136 & 0.044111 & 3.022076 & $\mathrm{Up}$ & STAG3L5P-PVRIG2P-PILRB readthrough \\
\hline ILMN_1754145 & CAPRIN1 & 0.293108 & 0.00032 & 0.014545 & 3.71836 & $\mathrm{Up}$ & cell cycle associated protein 1 \\
\hline ILMN_1730794 & SERTAD4 & 0.292851 & $9.6 \mathrm{E}-05$ & 0.008175 & 4.051978 & Up & SERTA domain containing 4 \\
\hline ILMN_2394250 & PLEKHA1 & 0.291747 & 0.002354 & 0.03774 & 3.115333 & $\mathrm{Up}$ & pleckstrin homology domain containing A1 \\
\hline ILMN_2078389 & SLC4A2 & 0.291257 & 0.001113 & 0.025759 & 3.35042 & Up & solute carrier family 4 member 2 \\
\hline ILMN_2220403 & GINM1 & 0.290762 & 0.000493 & 0.01788 & 3.593513 & $\mathrm{Up}$ & glycoprotein integral membrane 1 \\
\hline ILMN_1710027 & PNMT & 0.290062 & 0.0003 & 0.014133 & 3.736366 & $\mathrm{Up}$ & $\begin{array}{l}\text { phenylethanolamine N-methyltransferase } \\
\text { phosphatidylinositol-4-phosphate 5-kinase type }\end{array}$ \\
\hline ILMN_1734478 & PIP5K1B & 0.289858 & $5.33 \mathrm{E}-06$ & 0.002879 & 4.790836 & Up & 1 beta \\
\hline ILMN_1758034 & ETFDH & 0.288994 & 0.000644 & 0.019798 & 3.514851 & $\mathrm{Up}$ & electron transfer flavoprotein dehydrogenase \\
\hline ILMN_1666713 & LYPLA1 & 0.287789 & 0.00059 & 0.019114 & 3.541151 & $\mathrm{Up}$ & $\begin{array}{c}\text { lysophospholipase } 1 \\
\text { ADP ribosylation factor like GTPase } 6\end{array}$ \\
\hline ILMN_1797964 & ARL6IP6 & 0.287061 & 0.000378 & 0.015488 & 3.670358 & Up & $\begin{array}{l}\text { interacting protein } 6 \\
\text { phosphatidylinositol glycan anchor biosynthesis }\end{array}$ \\
\hline ILMN_3290211 & PIGH & 0.286739 & 0.00285 & 0.041916 & 3.053413 & $\mathrm{Up}$ & $\begin{array}{l}\text { class } \mathrm{H} \\
\text { heat shock protein } 90 \text { alpha family class A }\end{array}$ \\
\hline ILMN_1687546 & HSP90AA1 & 0.286692 & 0.000957 & 0.02406 & 3.396413 & $\mathrm{Up}$ & member 1 \\
\hline ILMN_1719344 & NRBF2 & 0.286671 & 0.002233 & 0.036626 & 3.132293 & $\mathrm{Up}$ & nuclear receptor binding factor 2 \\
\hline ILMN_1734655 & ATG9B & 0.286517 & 0.000583 & 0.01904 & 3.544278 & Up & autophagy related 9B \\
\hline ILMN_1711408 & ANXA4 & 0.286403 & 0.002191 & 0.036239 & 3.138437 & $\mathrm{Up}$ & annexin A4 \\
\hline
\end{tabular}




\begin{tabular}{|c|c|c|c|c|c|c|c|}
\hline ILMN_1669281 & CLN3 & 0.285791 & 0.000543 & 0.018404 & 3.565093 & Up & $\begin{array}{l}\text { CLN3 lysosomal/endosomaltransmembrane } \\
\text { protein, battenin }\end{array}$ \\
\hline ILMN_1686985 & MTM1 & 0.284755 & 0.00147 & 0.029797 & 3.264326 & $\mathrm{Up}$ & myotubularin 1 \\
\hline ILMN_1734229 & SPPL2A & 0.283933 & 0.001105 & 0.025674 & 3.352613 & $\mathrm{Up}$ & signal peptide peptidase like $2 \mathrm{~A}$ \\
\hline ILMN_2094166 & CHMP5 & 0.282317 & 0.002279 & 0.037103 & 3.125771 & $\mathrm{Up}$ & charged multivesicular body protein 5 \\
\hline ILMN_1773849 & ATP6V0C & 0.282222 & 0.000886 & 0.023276 & 3.419682 & $\mathrm{Up}$ & $\begin{array}{c}\text { ATPase } \mathrm{H}+\text { transporting V0 subunit } \mathrm{c} \\
\text { RAB3 GTPase activating protein catalytic }\end{array}$ \\
\hline ILMN_1739876 & RAB3GAP1 & 0.281181 & 0.001209 & 0.026753 & 3.324924 & $\mathrm{Up}$ & subunit 1 \\
\hline ILMN_1797594 & NFAT5 & 0.28094 & 0.002689 & 0.040538 & 3.072332 & Up & nuclear factor of activated $\mathrm{T}$ cells 5 \\
\hline ILMN_1734542 & OVGP1 & 0.280116 & 0.00204 & 0.035106 & 3.161242 & $\mathrm{Up}$ & oviductal glycoprotein 1 \\
\hline ILMN_1665982 & AKTIP & 0.277649 & 0.001862 & 0.03357 & 3.190258 & Up & AKT interacting protein \\
\hline ILMN_3249846 & LOC440895 & 0.276865 & 0.001178 & 0.026374 & 3.333032 & Up & $\begin{array}{l}\text { LIMS3-LOC440895 readthrough } \\
\text { LW }\end{array}$ \\
\hline ILMN_2323526 & WAC & 0.276545 & 0.000268 & 0.013383 & 3.769114 & $\mathrm{Up}$ & coil \\
\hline ILMN_1748077 & DDX59 & 0.275827 & 0.00214 & 0.035854 & 3.145909 & $\mathrm{Up}$ & DEAD-box helicase 59 \\
\hline ILMN_1782444 & YIPF4 & 0.275515 & 0.001307 & 0.027959 & 3.300882 & $\mathrm{Up}$ & Yip1 domain family member 4 \\
\hline ILMN_2339284 & CHD2 & 0.27514 & 0.000192 & 0.011354 & 3.862717 & $\mathrm{Up}$ & chromodomain helicase DNA binding protein 2 \\
\hline ILMN_1706342 & ZNF746 & 0.274797 & 0.001538 & 0.03037 & 3.250211 & $\mathrm{Up}$ & zinc finger protein 746 \\
\hline ILMN_3215367 & PPP4R2 & 0.274625 & 0.000744 & 0.021279 & 3.472213 & $\mathrm{Up}$ & protein phosphatase 4 regulatory subunit 2 \\
\hline ILMN_1687279 & DHPS & 0.274317 & 0.000812 & 0.022284 & 3.445971 & Up & deoxyhypusine synthase \\
\hline ILMN_1685678 & EEF1B2 & 0.273865 & 0.001055 & 0.025169 & 3.366614 & $\mathrm{Up}$ & eukaryotic translation elongation factor 1 beta 2 \\
\hline ILIVIN_1750/52 & COMHDI & 0.213015 & $0.001 / 12$ & 0.052109 & 5.210044 & up & comtanming 1 \\
\hline ILMN_2387090 & CGGBP1 & 0.273351 & 0.000341 & 0.01488 & 3.699974 & $\mathrm{Up}$ & CGG triplet repeat binding protein 1 \\
\hline ILMN_2194627 & GMCL1 & 0.273232 & 0.000277 & 0.013644 & 3.759819 & $\mathrm{Up}$ & germ cell-less 1 , spermatogenesis associated \\
\hline ILMN_3241234 & S100A11 & 0.273188 & 0.000851 & 0.022765 & 3.431703 & $\mathrm{Up}$ & S100 calcium binding protein A11 \\
\hline ILMN_1678454 & CASP4 & 0.27189 & 0.00153 & 0.030267 & 3.25192 & $\mathrm{Up}$ & caspase 4 \\
\hline ILMN_1705907 & NUP153 & 0.271384 & 0.000255 & 0.013135 & 3.782266 & Up & nucleoporin 153 \\
\hline ILMN_2106265 & GDPD1 & 0.271243 & 0.003428 & 0.046055 & 2.992682 & $\mathrm{Up}$ & domain containing 1 \\
\hline ILMN_1699357 & SLC22A5 & 0.270646 & 0.003156 & 0.044202 & 3.019938 & Up & $\begin{array}{l}\text { solute carrier family } 22 \text { member } 5 \\
\text { protein phosphatase } 1 \text { regulatory inhibitor }\end{array}$ \\
\hline ILMN_3282768 & PPP1R14B & 0.270021 & 0.001182 & 0.026432 & 3.331779 & $\mathrm{Up}$ & subunit 14B \\
\hline ILMN_1784655 & TLCD1 & 0.269664 & 0.001698 & 0.03211 & 3.219351 & Up & TLC domain containing 1 \\
\hline ILMN_1809344 & BTBD10 & 0.269367 & 0.003946 & 0.049535 & 2.945897 & $\mathrm{Up}$ & BTB domain containing 10 \\
\hline ILMN_1651268 & BORCS5 & 0.268841 & 0.000523 & 0.0181 & 3.576152 & $\mathrm{Up}$ & BLOC-1 related complex subunit 5 \\
\hline ILMN_1676385 & PAK2 & 0.268282 & 0.000156 & 0.010361 & 3.920545 & $\mathrm{Up}$ & p21 (RAC1) activated kinase 2 \\
\hline ILMN_1658337 & AKIRIN1 & 0.268214 & 0.003147 & 0.04417 & 3.020957 & $\mathrm{Up}$ & akirin 1 \\
\hline ILMN_2137464 & DVL3 & 0.267864 & 0.0012 & 0.026647 & 3.327306 & $\mathrm{Up}$ & dishevelled segment polarity protein 3 \\
\hline ILMN_1721833 & IER5 & 0.26766 & 0.003092 & 0.043799 & 3.026706 & Up & immediate early response 5 \\
\hline ILMN_1781431 & GLCCI1 & 0.267281 & $8.05 \mathrm{E}-05$ & 0.007462 & 4.099378 & $\mathrm{Up}$ & glucocorticoid induced 1 \\
\hline ILMN_1808824 & NEBL & 0.266945 & 0.001597 & 0.031164 & 3.238616 & Up & nebulette \\
\hline ILMN_1813028 & CBX5 & 0.266695 & 4.39E-05 & 0.005755 & 4.259566 & $\mathrm{Up}$ & chromobox 5 \\
\hline ILMN_1717745 & TIAL1 & 0.266333 & $6.37 \mathrm{E}-06$ & 0.00295 & 4.747368 & $\mathrm{Up}$ & $\begin{array}{c}\text { TIA1 cytotoxic granule associated RNA } \\
\text { binding protein like } 1\end{array}$ \\
\hline
\end{tabular}




\begin{tabular}{|c|c|c|c|c|c|c|c|}
\hline ILMN_1735052 & ULK1 & 0.266063 & 0.002947 & 0.042626 & 3.042442 & Up & unc-51 like autophagy activating kinase 1 \\
\hline ILMN_1666670 & $\mathrm{RBX} 1$ & 0.265833 & $9.11 \mathrm{E}-06$ & 0.003026 & 4.659225 & Up & ring-box 1 \\
\hline ILMN_1801476 & CDS1 & 0.265788 & 0.002179 & 0.036176 & 3.140131 & Up & CDP-diacylglycerol synthase 1 \\
\hline ILMN_1707350 & TUSC1 & 0.265484 & 0.002186 & 0.036205 & 3.139179 & Up & tumor suppressor candidate 1 \\
\hline ILMN_1671265 & ING2 & 0.264936 & 0.000146 & 0.010103 & 3.937352 & Up & inhibitor of growth family member 2 \\
\hline ILMN_1776297 & GOLGA4 & 0.262744 & 0.001009 & 0.024621 & 3.380238 & Up & golgin A4 \\
\hline ILMN_1717063 & FBXO9 & 0.262663 & $5.06 \mathrm{E}-06$ & 0.002879 & 4.803593 & Up & F-box protein 9 \\
\hline ILMN_1791826 & RAB25 & 0.262537 & 0.003142 & 0.04417 & 3.021403 & Up & RAB25, member RAS oncogene family \\
\hline ILMN_1704550 & AZIN1 & 0.262282 & 0.002375 & 0.03792 & 3.112496 & Up & antizyme inhibitor 1 \\
\hline ILMN_1660111 & UCHL3 & 0.262244 & $4.55 \mathrm{E}-05$ & 0.005773 & 4.250481 & Up & ubiquitin C-terminal hydrolase L3 \\
\hline ILMN_1709043 & PLGRKT & 0.26194 & 0.001065 & 0.025246 & 3.363896 & Up & plasminogen receptor with a C-terminal lysine \\
\hline ILMN_1695961 & CLK3 & 0.261157 & $6.84 \mathrm{E}-05$ & 0.006944 & 4.142743 & Up & $\begin{array}{l}\text { CDC like kinase } 3 \\
\text { thiosulfate sulfurtransferase like domain }\end{array}$ \\
\hline ILMN_3197097 & TSTD1 & 0.260702 & 0.000162 & 0.010401 & 3.909022 & Up & containing 1 \\
\hline ILMN_1792497 & AGFG1 & 0.259601 & 0.000823 & 0.022397 & 3.442009 & Up & ArfGAP with FG repeats 1 \\
\hline ILMN_1684346 & TNFAIP8L1 & 0.259593 & 0.001641 & 0.031522 & 3.229929 & Up & TNF alpha induced protein 8 like 1 \\
\hline ILMN_1737475 & ABHD11 & 0.259331 & 0.002117 & 0.035667 & 3.149412 & $\mathrm{Up}$ & abhydrolase domain containing 11 \\
\hline ILMN_1682147 & HOOK2 & 0.258381 & 0.000116 & 0.009 & 4.000611 & Up & $\begin{array}{l}\text { hook microtubule tethering protein } 2 \\
\text { leucine zipper tumor suppressor family member }\end{array}$ \\
\hline ILMN_1736154 & LZTS3 & 0.257357 & 0.000288 & 0.013983 & 3.747905 & Up & 3 \\
\hline ILMN_2328776 & STK26 & 0.257332 & 0.003144 & 0.04417 & 3.021189 & Up & serine/threonine kinase 26 \\
\hline ILMN_3246900 & LINC01278 & 0.255848 & 0.002475 & 0.03872 & 3.09914 & Up & long intergenic non-protein coding RNA 1278 \\
\hline ILMN_1702407 & SPIN1 & 0.255702 & 0.001221 & 0.026874 & 3.322 & $\mathrm{Up}$ & spindlin 1 \\
\hline ILMN_2344956 & ACP1 & 0.255631 & 0.001788 & 0.032895 & 3.202956 & $\mathrm{Up}$ & acid phosphatase 1 \\
\hline ILMN_1685415 & HBP1 & 0.25552 & 0.00362 & 0.04748 & 2.974605 & Up & HMG-box transcription factor 1 \\
\hline ILMN_2399264 & $\begin{array}{c}\text { SEPTIN6 } \\
\text { CSGALNACT }\end{array}$ & 0.25419 & 0.000112 & 0.008891 & 4.010048 & Up & $\begin{array}{c}\text { septin } 6 \\
\text { chondroitin sulfate } \mathrm{N} \text { - }\end{array}$ \\
\hline ILMN_2055523 & 1 & 0.253386 & 0.002808 & 0.041529 & 3.058213 & Up & acetylgalactosaminyltransferase 1 \\
\hline ILMN_3279712 & SMS & 0.252553 & 0.001715 & 0.032189 & 3.216153 & Up & spermine synthase \\
\hline ILMN_1701514 & TRAF3IP2 & 0.252377 & 0.003172 & 0.044294 & 3.018317 & Up & TRAF3 interacting protein 2 \\
\hline ILMN_3227529 & RPS13 & 0.252336 & 0.000401 & 0.01601 & 3.65339 & Up & ribosomal protein $\mathrm{S} 13$ \\
\hline ILMN_1680397 & CXCR2 & 0.251961 & 0.000716 & 0.020858 & 3.483454 & Up & $\mathrm{C}-\mathrm{X}-\mathrm{C}$ motif chemokine receptor 2 \\
\hline ILMN_1661142 & TMF1 & 0.251932 & 0.000831 & 0.02251 & 3.439126 & Up & TATA element modulatory factor 1 \\
\hline ILMN_2228044 & TBC1D23 & 0.251655 & $5.18 \mathrm{E}-06$ & 0.002879 & 4.797583 & Up & TBC1 domain family member 23 \\
\hline ILMN_2352326 & COASY & 0.25148 & 0.003205 & 0.044541 & 3.014949 & Up & Coenzyme A synthase \\
\hline ILMN_1753457 & PKP3 & 0.251362 & 0.000802 & 0.02216 & 3.449557 & Up & plakophilin 3 \\
\hline ILMN_2081673 & INSL6 & 0.250409 & 6.77E-06 & 0.00295 & 4.732468 & Up & insulin like 6 \\
\hline ILMN_1743396 & ACOX3 & 0.250377 & 0.001149 & 0.026102 & 3.340671 & $\mathrm{Up}$ & acyl-CoA oxidase 3, pristanoyl \\
\hline ILMN_1711786 & NFE2 & 0.250104 & 0.001205 & 0.026691 & 3.326009 & Up & $\begin{array}{l}\text { nuclear factor, erythroid } 2 \\
\text { capping actin protein of muscle Z-line subunit }\end{array}$ \\
\hline ILMN_3289090 & CAPZA1 & 0.24988 & 0.001472 & 0.029809 & 3.263922 & Up & alpha 1 \\
\hline ILMN_2151056 & BORCS7 & 0.249315 & 0.000261 & 0.013186 & 3.776529 & Up & BLOC-1 related complex subunit 7 \\
\hline ILMN_1716195 & $\mathrm{H} 2 \mathrm{BC} 8$ & 0.248687 & 0.00072 & 0.020871 & 3.481999 & Up & H2B clustered histone 8 \\
\hline ILMN_2366864 & JUP & 0.248584 & 0.003341 & 0.045507 & 3.001191 & Up & junction plakoglobin \\
\hline ILMN_1709026 & PXDC1 & 0.248166 & 0.00183 & 0.033266 & 3.19572 & Up & $\begin{array}{l}\text { PX domain containing } 1 \\
\text { heat shock protein } 90 \text { beta family member } 3 \text {, } \\
\text { pseudogene }\end{array}$ \\
\hline
\end{tabular}




\begin{tabular}{|c|c|c|c|c|c|c|c|}
\hline ILMN_1662880 & LINC01554 & 0.248026 & 0.000163 & 0.010418 & 3.908142 & Up & $\begin{array}{l}\text { long intergenic non-protein coding RNA } 1554 \\
\text { dual specificity tyrosine phosphorylation }\end{array}$ \\
\hline ILMN_1664560 & $\begin{array}{l}\text { DYRK1A } \\
\text { SERTAD4- }\end{array}$ & 0.248006 & 0.003816 & 0.048801 & 2.957108 & Up & regulated kinase $1 \mathrm{~A}$ \\
\hline ILMN_3241665 & AS1 & 0.247969 & $2.49 \mathrm{E}-05$ & 0.004816 & 4.406676 & Up & SERTAD4 antisense RNA 1 \\
\hline ILMN_2347541 & NIN & 0.24778 & 0.002743 & 0.041015 & 3.065875 & Up & ninein \\
\hline ILMN_3185198 & ACTR3C & 0.247744 & 0.000969 & 0.024168 & 3.392602 & Up & $\begin{array}{c}\text { actin related protein } 3 \mathrm{C} \\
\text { serine palmitoyltransferase long chain base }\end{array}$ \\
\hline ILMN_2274420 & SPTLC1 & 0.247643 & 0.001511 & 0.030094 & 3.255789 & Up & subunit 1 \\
\hline ILMN_2356654 & LGALS8 & 0.247618 & 0.000254 & 0.013135 & 3.783998 & Up & galectin 8 \\
\hline ILMN_1711792 & GPBP1 & 0.246944 & 0.000145 & 0.010064 & 3.939077 & Up & GC-rich promoter binding protein 1 \\
\hline ILMN_1785765 & TM9SF2 & 0.246663 & 0.003558 & 0.047012 & 2.980358 & Up & transmembrane 9 superfamily member 2 \\
\hline ILMN_1739967 & TBK1 & 0.246267 & 0.000318 & 0.01452 & 3.72025 & Up & TANK binding kinase 1 \\
\hline ILMN_1737005 & SMG9 & 0.245801 & 9.57E-06 & 0.003088 & 4.647172 & Up & SMG9 nonsense mediated mRNA decay factor \\
\hline ILMN_3243514 & PP12613 & 0.245456 & $5.23 \mathrm{E}-05$ & 0.006073 & 4.213967 & Up & uncharacterized LOC100192379 \\
\hline ILMN_2113938 & TOR1AIP2 & 0.245454 & 0.001286 & 0.027708 & 3.306016 & Up & torsin $1 \mathrm{~A}$ interacting protein 2 \\
\hline ILMN_1669905 & DCP2 & 0.24544 & 0.001721 & 0.032249 & 3.215129 & Up & $\begin{array}{l}\text { decapping mRNA } 2 \\
\text { TATA-hox binding }\end{array}$ \\
\hline ILMN_1667977 & TAF1B & 0.245081 & 0.000116 & 0.009 & 4.001937 & Up & RNA polymerase I subunit B \\
\hline ILMN_1765212 & LARP1B & 0.244844 & 0.001587 & 0.031031 & 3.240414 & Up & La ribonucleoprotein 1B \\
\hline ILMN_2275248 & ECE2 & 0.244549 & 0.000156 & 0.010362 & 3.919402 & Up & endothelin converting enzyme 2 \\
\hline ILMN_1697864 & CXorf38 & 0.243864 & 7.18E-05 & 0.007104 & 4.130027 & Up & chromosome $\mathrm{X}$ open reading frame 38 \\
\hline ILMN_1771286 & PDE4DIP & 0.242808 & 0.001603 & 0.031243 & 3.237261 & Up & phosphodiesterase $4 \mathrm{D}$ interacting protein \\
\hline ILMN_1804064 & ESRRG & 0.242656 & $2.74 \mathrm{E}-05$ & 0.004869 & 4.381513 & Up & estrogen related receptor gamma \\
\hline ILMN_1808860 & STX5 & 0.241476 & 0.001945 & 0.034306 & 3.176409 & Up & syntaxin 5 \\
\hline ILMN_2359345 & NET1 & 0.241323 & 0.001147 & 0.026081 & 3.341062 & Up & neuroepithelial cell transforming 1 \\
\hline ILMN_2324157 & UBA3 & 0.24102 & 0.000534 & 0.018273 & 3.570218 & Up & ubiquitin like modifier activating enzyme 3 \\
\hline ILMN_1778803 & ZFAND6 & 0.239907 & 0.002388 & 0.037999 & 3.110718 & Up & $\begin{array}{l}\text { zinc finger AN1-type containing } 6 \\
\text { SH3 domain containing kinase binding protein }\end{array}$ \\
\hline ILMN_1810782 & SH3KBP1 & 0.239001 & 0.003315 & 0.045247 & 3.003739 & Up & 1 \\
\hline ILMN_1666258 & AMFR & 0.238013 & 0.002066 & 0.035418 & 3.157186 & Up & autocrine motility factor receptor \\
\hline ILMN_1776154 & COG3 & 0.237721 & 0.001616 & 0.031301 & 3.234779 & Up & component of oligomericgolgi complex 3 \\
\hline ILMN_2387553 & PSMA3 & 0.237489 & 0.000128 & 0.009505 & 3.973908 & Up & proteasome $20 \mathrm{~S}$ subunit alpha 3 \\
\hline ILMN_1730630 & CXorf56 & 0.236626 & 0.002038 & 0.035103 & 3.1615 & Up & chromosome $\mathrm{X}$ open reading frame 56 \\
\hline ILMN_1673380 & GNG12 & 0.236565 & 0.003033 & 0.04332 & 3.033043 & Up & G protein subunit gamma 12 \\
\hline ILMN_3247111 & LRRC69 & 0.233635 & 0.000701 & 0.020587 & 3.489939 & Up & leucine rich repeat containing 69 \\
\hline ILMN_1757956 & PCGF1 & 0.23308 & 0.000729 & 0.021012 & 3.478289 & Up & polycomb group ring finger 1 \\
\hline ILMN_1759460 & TAF7 & 0.232964 & $1.99 \mathrm{E}-06$ & 0.002078 & 5.027658 & Up & TATA-box binding protein associated factor 7 \\
\hline ILMN_1747241 & IWS1 & 0.232787 & 0.00339 & 0.045729 & 2.996419 & Up & interacts with SUPT6H, CTD assembly factor 1 \\
\hline ILMN_1676763 & PIPSL & 0.232594 & 0.000323 & 0.014545 & 3.715885 & Up & PIP5K1A and PSMD4 like (pseudogene) \\
\hline ILMN_1813148 & TOM1 & 0.23244 & 0.002966 & 0.04284 & 3.040312 & Up & target of myb1 membrane trafficking protein \\
\hline ILMN_3240721 & TDG & 0.231924 & 0.000256 & 0.013135 & 3.782108 & Up & thymine DNA glycosylase \\
\hline ILMN_1682919 & PAFAH2 & 0.231731 & 0.002527 & 0.039088 & 3.09253 & Up & platelet activating factor acetylhydrolase 2 \\
\hline ILMN_2306077 & USP33 & 0.231641 & $1.33 \mathrm{E}-05$ & 0.00347 & 4.564689 & Up & ubiquitin specific peptidase 33 \\
\hline ILMN_2413572 & MARK2 & 0.231373 & 0.003901 & 0.049215 & 2.94973 & Up & microtubule affinity regulating kinase 2 \\
\hline ILMN_2320853 & UBE2D3 & 0.230668 & 0.001111 & 0.025736 & 3.351016 & Up & ubiquitin conjugating enzyme E2 D3 \\
\hline ILMN_1760256 & RBM22 & 0.230632 & 0.001806 & 0.033086 & 3.199833 & Up & RNA binding motif protein 22 \\
\hline
\end{tabular}




\begin{tabular}{|c|c|c|c|c|c|c|c|}
\hline ILMN_1658743 & CCNDBP1 & 0.229972 & 9.97E-05 & 0.008353 & 4.04187 & Up & $\begin{array}{l}\text { cyclin D1 binding protein } 1 \\
\text { protein tyrosine phosphatase non-receptor type }\end{array}$ \\
\hline ILMN_1717294 & PTPN3 & 0.229265 & 0.002347 & 0.037683 & 3.116328 & Up & 3 \\
\hline ILMN_2101920 & HNRNPH1 & 0.229246 & 0.000147 & 0.010107 & 3.93673 & Up & heterogeneous nuclear ribonucleoprotein $\mathrm{H} 1$ \\
\hline ILMN_1736234 & CHTOP & 0.228517 & 0.001144 & 0.026058 & 3.341855 & Up & chromatin target of PRMT1 \\
\hline ILMN_1700384 & KIAA1522 & 0.228516 & 0.000577 & 0.018974 & 3.547666 & Up & KIAA1522 \\
\hline ILMN_1719237 & SPDYE8P & 0.228465 & 0.00384 & 0.048887 & 2.954952 & Up & $\begin{array}{l}\text { speedy/RINGO cell cycle regulator family } \\
\text { member E8, pseudogene }\end{array}$ \\
\hline ILMN_1701724 & GET4 & 0.228197 & 0.000247 & 0.012906 & 3.79222 & Up & guided entry of tail-anchored proteins factor 4 \\
\hline ILMN_1785852 & NABP1 & 0.227819 & 0.002071 & 0.035437 & 3.156321 & Up & nucleic acid binding protein 1 \\
\hline ILMN_1755649 & SLC16A5 & 0.227432 & 0.001462 & 0.029722 & 3.266055 & Up & solute carrier family 16 member 5 \\
\hline ILMN_1742118 & RNASE12 & 0.226586 & 0.000101 & 0.008365 & 4.039673 & Up & ribonuclease A family member 12 (inactive) \\
\hline ILMN_1701169 & HP1BP3 & 0.226445 & 0.000651 & 0.019899 & 3.512006 & Up & $\begin{array}{l}\text { heterochromatin protein } 1 \text { binding protein } 3 \\
\text { adaptor related protein complex } 1 \text { subunit }\end{array}$ \\
\hline ILMN_1754179 & AP1G2 & 0.226367 & 0.000599 & 0.019237 & 3.536286 & Up & gamma 2 \\
\hline ILMN_2396813 & BABAM1 & 0.226351 & 0.000283 & 0.013823 & 3.753519 & Up & BRISC and BRCA1 A complex member 1 \\
\hline ILMN_1726589 & CD248 & -0.87731 & $6.86 \mathrm{E}-05$ & 0.006945 & -4.14215 & Down & $\begin{array}{l}\text { CD248 molecule } \\
\text { peptidase domain containing associated with }\end{array}$ \\
\hline ILMN_1658356 & PAMR1 & -0.77303 & $1.88 \mathrm{E}-07$ & 0.000867 & -5.57122 & Down & muscle regeneration 1 \\
\hline ILMN_1701308 & COL1A1 & -0.77213 & $5.05 \mathrm{E}-07$ & 0.001127 & -5.34677 & Down & collagen type I alpha 1 chain \\
\hline ILMN_1723522 & APOLD1 & -0.75887 & 0.00051 & 0.017953 & -3.58362 & Down & apolipoprotein $\mathrm{L}$ domain containing 1 \\
\hline ILMN_1779875 & THY1 & -0.75181 & $3.89 \mathrm{E}-05$ & 0.005414 & -4.29148 & Down & Thy-1 cell surface antigen \\
\hline ILMN_1696347 & CTSC & -0.73439 & 0.000361 & 0.015151 & -3.68404 & Down & cathepsin C \\
\hline ILMN_1706505 & COL5A1 & -0.68289 & $8.23 \mathrm{E}-08$ & 0.000792 & -5.75462 & Down & collagen type $\mathrm{V}$ alpha 1 chain \\
\hline ILMN_3237946 & PXDN & -0.68073 & 4.96E-06 & 0.002879 & -4.80838 & Down & peroxidasin \\
\hline ILMN_1673639 & АВІ3ВР & -0.67199 & 0.000934 & 0.023743 & -3.40373 & Down & ABI family member 3 binding protein \\
\hline ILMN_1766914 & MFAP4 & -0.66612 & $4.35 \mathrm{E}-06$ & 0.002772 & -4.84032 & Down & microfibril associated protein 4 \\
\hline ILMN_1795325 & ACTG2 & -0.65224 & 0.000984 & 0.024307 & -3.38785 & Down & actin gamma 2 , smooth muscle \\
\hline ILMN_1757604 & TPM2 & -0.65 & 0.00014 & 0.00984 & -3.94965 & Down & tropomyosin 2 \\
\hline ILMN_1706643 & COL6A3 & -0.64553 & $2.54 \mathrm{E}-05$ & 0.004833 & -4.40149 & Down & collagen type VI alpha 3 chain \\
\hline ILMN_1725193 & IGFBP2 & -0.63091 & 0.001035 & 0.024881 & -3.3724 & Down & insulin like growth factor binding protein 2 \\
\hline ILMN_1720231 & TNNT3 & -0.61868 & 0.000693 & 0.020442 & -3.49345 & Down & troponin $\mathrm{T} 3$, fast skeletal type \\
\hline ILMN_2104356 & COL1A2 & -0.60473 & $8.52 \mathrm{E}-06$ & 0.00295 & -4.67573 & Down & collagen type I alpha 2 chain \\
\hline ILMN_1773079 & COL3A1 & -0.6033 & $5.14 \mathrm{E}-06$ & 0.002879 & -4.79969 & Down & collagen type III alpha 1 chain \\
\hline ILMN_1707070 & PCOLCE & -0.59908 & $1.55 \mathrm{E}-06$ & 0.001955 & -5.0867 & Down & procollagen C-endopeptidase enhancer \\
\hline ILMN_1797776 & PRSS23 & -0.59791 & $1.36 \mathrm{E}-06$ & 0.001955 & -5.11653 & Down & serine protease 23 \\
\hline ILMN_2390919 & FBLN2 & -0.59331 & $6.9 \mathrm{E}-06$ & 0.00295 & -4.72775 & Down & fibulin 2 \\
\hline ILMN_1712046 & CPXM1 & -0.59179 & 0.000142 & 0.009889 & -3.94586 & Down & carboxypeptidase X, M14 family member 1 \\
\hline ILMN_1670379 & ANTXR1 & -0.59159 & $3.06 \mathrm{E}-05$ & 0.005173 & -4.35299 & Down & ANTXR cell adhesion molecule 1 \\
\hline ILMN_1743445 & FAM107A & -0.58708 & 0.001007 & 0.02461 & -3.38091 & Down & family with sequence similarity 107 member A \\
\hline ILMN_1697268 & EMILIN2 & -0.58178 & $2.61 \mathrm{E}-05$ & 0.004833 & -4.39456 & Down & elastin microfibrilinterfacer 2 \\
\hline ILMN_1756071 & MFGE8 & -0.58136 & 0.00023 & 0.012505 & -3.81152 & Down & milk fat globule-EGF factor 8 protein \\
\hline ILMN_2115125 & $\mathrm{CCN} 2$ & -0.56274 & 0.00135 & 0.028444 & -3.29078 & Down & cellular communication network factor 2 \\
\hline ILMN_1700690 & VAT1 & -0.55561 & $1.38 \mathrm{E}-05$ & 0.003478 & -4.55564 & Down & $\begin{array}{c}\text { vesicle amine transport } 1 \\
\text { protein phosphatase } 1 \text { regulatory inhibitor }\end{array}$ \\
\hline IIVIN_1/01900 & РPFINI4A & -0.50302 & $0.505-00$ & 0.00290 & $-4.14 / 11$ & DOwII & \\
\hline ILMN_1783909 & COL6A2 & -0.55352 & $3.46 \mathrm{E}-05$ & 0.005189 & -4.32174 & Down & collagen type VI alpha 2 chain \\
\hline
\end{tabular}




\begin{tabular}{|c|c|c|c|c|c|c|c|}
\hline ILMN_2384056 & GPER1 & -0.55173 & 0.001275 & 0.027557 & -3.30852 & Down & G protein-coupled estrogen receptor 1 \\
\hline ILMN_1688642 & LAMC3 & -0.54794 & 0.000167 & 0.010606 & -3.90071 & Down & laminin subunit gamma 3 \\
\hline ILMN_1779558 & GAS6 & -0.54545 & 4.6E-07 & 0.001127 & -5.36823 & Down & growth arrest specific 6 \\
\hline ILMN_1800787 & RFTN1 & -0.54246 & $9.71 \mathrm{E}-06$ & 0.003091 & -4.6434 & Down & raftlin, lipid raft linker 1 \\
\hline ILMN_1665909 & LASP1 & -0.53453 & $1.44 \mathrm{E}-06$ & 0.001955 & -5.10383 & Down & LIM and SH3 protein 1 \\
\hline ILMN_1811313 & SLIT3 & -0.53304 & 5.6E-08 & 0.000792 & -5.83956 & Down & slit guidance ligand 3 \\
\hline ILMN_1793476 & CAVIN3 & -0.5317 & $2.2 \mathrm{E}-05$ & 0.004675 & -4.43772 & Down & caveolae associated protein 3 \\
\hline ILMN_2307903 & VCAM1 & -0.53139 & $8.12 \mathrm{E}-05$ & 0.007511 & -4.09693 & Down & $\begin{array}{l}\text { vascular cell adhesion molecule } 1 \\
\text { prostate androgen-regulated mucin-like protein }\end{array}$ \\
\hline ILMN_1656560 & PARM1 & -0.53103 & 0.00016 & 0.010366 & -3.91255 & Down & 1 \\
\hline ILMN_1672611 & CDH11 & -0.52302 & 0.000212 & 0.011964 & -3.83473 & Down & cadherin 11 \\
\hline ILMN_1765557 & OLFML2B & -0.52097 & $4.2 \mathrm{E}-06$ & 0.00273 & -4.84868 & Down & olfactomedin like $2 \mathrm{~B}$ \\
\hline ILMN_1815057 & PDGFRB & -0.52016 & $1.82 \mathrm{E}-05$ & 0.004138 & -4.48559 & Down & platelet derived growth factor receptor beta \\
\hline ILMN_1736178 & AEBP1 & -0.5199 & 3.33E-05 & 0.005189 & -4.33169 & Down & AE binding protein 1 \\
\hline ILMN_1748124 & TSC22D3 & -0.51824 & 0.000928 & 0.02368 & -3.40564 & Down & TSC22 domain family member 3 \\
\hline ILMN_1723978 & LGALS1 & -0.51718 & 0.000364 & 0.015227 & -3.68144 & Down & galectin 1 \\
\hline ILMN_1738147 & NES & -0.51576 & $8.77 \mathrm{E}-06$ & 0.003014 & -4.6686 & Down & nestin \\
\hline ILMN_2301722 & PDE8B & -0.51488 & $2.73 \mathrm{E}-05$ & 0.004869 & -4.38289 & Down & phosphodiesterase 8B \\
\hline ILMN_1687301 & VCAN & -0.51483 & 0.000221 & 0.012223 & -3.82288 & Down & versican \\
\hline ILMN_1778523 & KLF9 & -0.50597 & $5.25 \mathrm{E}-05$ & 0.006073 & -4.21296 & Down & Kruppel like factor 9 \\
\hline ILMN_2062468 & IGFBP7 & -0.50184 & 0.000947 & 0.023893 & -3.3994 & Down & insulin like growth factor binding protein 7 \\
\hline ILMN_1748323 & CXCL14 & -0.49871 & 0.000454 & 0.017215 & -3.61778 & Down & C-X-C motif chemokine ligand 14 \\
\hline ILMN_1751326 & FAM162B & -0.49815 & 0.00278 & 0.041278 & -3.06149 & Down & $\begin{array}{l}\text { family with sequence similarity } 162 \text { member B } \\
\text { ectonucleotidepyrophosphatase/phosphodiestera }\end{array}$ \\
\hline ILMN_2373791 & ENPP2 & -0.49776 & $6.94 \mathrm{E}-05$ & 0.006958 & -4.13908 & Down & se 2 \\
\hline ILMN_1752968 & LAMB2 & -0.49708 & 0.000303 & 0.014156 & -3.73363 & Down & $\begin{array}{l}\text { laminin subunit beta } 2 \\
\text { hes related family bHLH transcription factor }\end{array}$ \\
\hline ILMN_1654324 & HEYL & -0.49611 & 0.000102 & 0.008419 & -4.03652 & Down & with YRPW motif like \\
\hline ILMN_1667295 & VASN & -0.49482 & $1.16 \mathrm{E}-05$ & 0.003364 & -4.5987 & Down & $\begin{array}{l}\text { vasorin } \\
\text { ArfGAP with RhoGAP }\end{array}$ \\
\hline ILMN_1812618 & ARAP3 & -0.49404 & 0.003139 & 0.044148 & -3.0217 & Down & and $\mathrm{PH}$ domain 3 \\
\hline ILMN_1661599 & DDIT4 & -0.49301 & 0.002513 & 0.039003 & -3.09422 & Down & $\begin{array}{l}\text { DNA damage inducible transcript } 4 \\
\text { ST3 beta-galactoside alpha-2,3-sialyltransferase }\end{array}$ \\
\hline ILMN_1713496 & ST3GAL5 & -0.492 & 8.48E-05 & 0.007599 & -4.08534 & Down & 5 \\
\hline ILMN_1665865 & IGFBP4 & -0.49057 & 0.002826 & 0.041676 & -3.05613 & Down & insulin like growth factor binding protein 4 \\
\hline ILMN_1687652 & TGFB3 & -0.48958 & 0.002071 & 0.035437 & -3.15638 & Down & transforming growth factor beta 3 \\
\hline ILMN_1801616 & EMP1 & -0.48942 & 0.000266 & 0.013333 & -3.77097 & Down & $\begin{array}{l}\text { epithelial membrane protein } 1 \\
\text { transmembrane and immunoglobulin domain }\end{array}$ \\
\hline ILMN_1733259 & TMIGD3 & -0.48909 & 0.00024 & 0.012746 & -3.79958 & Down & containing 3 \\
\hline ILMN_1670490 & PDPN & -0.48881 & 0.000138 & 0.009821 & -3.95297 & Down & $\begin{array}{l}\text { podoplanin } \\
\text { latent transforming growth factor beta binding }\end{array}$ \\
\hline ILMN_1665219 & LTBP4 & -0.4882 & $1.05 \mathrm{E}-07$ & 0.000838 & -5.70174 & Down & protein 4 \\
\hline ILMN_1738578 & FILIP1L & -0.48742 & 0.000178 & 0.010961 & -3.88315 & Down & $\begin{array}{l}\text { filamin A interacting protein } 1 \text { like } \\
\text { EGF like, fibronectin type III and laminin G }\end{array}$ \\
\hline ILMN_1654109 & EGFLAM & -0.48718 & 0.000239 & 0.012746 & -3.80108 & Down & domains \\
\hline ILMN_1796734 & SPARC & -0.48641 & $1.76 \mathrm{E}-05$ & 0.004057 & -4.49427 & Down & secreted protein acidic and cysteine rich \\
\hline ILMN_1675797 & EPDR1 & -0.48638 & 0.002889 & 0.0423 & -3.04891 & Down & ependymin related 1 \\
\hline ILMN_1752755 & VWF & -0.48403 & 0.000698 & 0.02056 & -3.491 & Down & von Willebrand factor \\
\hline ILMN_1743836 & MXRA7 & -0.48256 & 0.000135 & 0.009758 & -3.9585 & Down & matrix remodeling associated 7 \\
\hline ILMN_1732151 & COL6A1 & -0.48252 & 0.000537 & 0.018298 & -3.56848 & Down & collagen type VI alpha 1 chain \\
\hline
\end{tabular}




\begin{tabular}{|c|c|c|c|c|c|c|c|}
\hline ILMN_1699695 & TNFRSF2 1 & -0.48252 & $3.82 \mathrm{E}-07$ & 0.001058 & -5.41081 & Down & TNF receptor superfamily member 21 \\
\hline ILMN_1671703 & ACTA2 & -0.48127 & 0.001006 & 0.024602 & -3.3812 & Down & actin alpha 2 , smooth muscle \\
\hline ILMN_1777190 & CFD & -0.48004 & 0.001794 & 0.032947 & -3.20188 & Down & complement factor D \\
\hline ILMN_1785646 & PMP22 & -0.47862 & $1.24 \mathrm{E}-05$ & 0.003412 & -4.58237 & Down & peripheral myelin protein 22 \\
\hline ILMN_1795166 & PTH1R & -0.47706 & $1.22 \mathrm{E}-05$ & 0.003404 & -4.58718 & Down & parathyroid hormone 1 receptor \\
\hline ILMN_1779182 & TMEM98 & -0.47485 & $3.81 \mathrm{E}-06$ & 0.002678 & -4.87203 & Down & $\begin{array}{c}\text { transmembrane protein } 98 \\
\text { latent transforming growth factor beta binding }\end{array}$ \\
\hline ILMN_3248591 & LTBP2 & -0.47272 & $3.28 \mathrm{E}-05$ & 0.005189 & -4.33519 & Down & protein 2 \\
\hline ILMN_1672503 & DPYSL2 & -0.47143 & $5.37 \mathrm{E}-06$ & 0.002879 & -4.78877 & Down & dihydropyrimidinase like 2 \\
\hline ILMN_2223941 & FBLN5 & -0.47095 & $1.94 \mathrm{E}-06$ & 0.002072 & -5.03358 & Down & fibulin 5 \\
\hline ILMN_1688480 & CCND1 & -0.46977 & 0.000483 & 0.017744 & -3.59964 & Down & cyclin D1 \\
\hline ILMN_1808114 & LYVE1 & -0.46936 & 0.003925 & 0.049436 & -2.9477 & Down & $\begin{array}{l}\text { lymphatic vessel endothelial hyaluronan } \\
\text { receptor } 1\end{array}$ \\
\hline ILMN_2087692 & CYBRD1 & -0.46894 & $2.69 \mathrm{E}-05$ & 0.004861 & -4.38626 & Down & cytochrome $\mathrm{b}$ reductase 1 \\
\hline ILMN_1808707 & FSCN1 & -0.46767 & 3.69E-05 & 0.005267 & -4.30499 & Down & fascin actin-bundling protein 1 \\
\hline ILMN_1660808 & WFDC1 & -0.46665 & 0.000163 & 0.010418 & -3.90783 & Down & WAP four-disulfide core domain 1 \\
\hline ILMN_2337655 & WARS1 & -0.4653 & 4.87E-05 & 0.005873 & -4.23248 & Down & tryptophanyl-tRNAsynthetase 1 \\
\hline ILMN_2347145 & $\mathrm{DCN}$ & -0.46414 & $8.34 \mathrm{E}-05$ & 0.007533 & -4.08985 & Down & decorin \\
\hline ILMN_1694840 & MATN2 & -0.46405 & 0.000542 & 0.018404 & -3.56578 & Down & matrilin 2 \\
\hline ILMN_1729117 & COL5A2 & -0.46318 & 0.000177 & 0.010947 & -3.88468 & Down & collagen type $\mathrm{V}$ alpha 2 chain \\
\hline ILMN_1681983 & RSPO3 & -0.46314 & 0.000248 & 0.012955 & -3.79059 & Down & R-spondin 3 \\
\hline ILMN_3246401 & AIF1L & -0.46241 & 0.000187 & 0.011245 & -3.86955 & Down & allograft inflammatory factor 1 like \\
\hline ILMN_1778668 & TAGLN & -0.46167 & 0.001483 & 0.029912 & -3.26159 & Down & transgelin \\
\hline ILMN_1700183 & APLNR & -0.46027 & 0.000159 & 0.010362 & -3.91414 & Down & apelin receptor \\
\hline ILMN_2413158 & PODXL & -0.45912 & 0.000113 & 0.008916 & -4.0078 & Down & podocalyxin like \\
\hline ILMN_1701877 & AXL & -0.45803 & $3.57 \mathrm{E}-05$ & 0.005231 & -4.31359 & Down & AXL receptor tyrosine kinase \\
\hline ILMN_1676893 & $\mathrm{ADCY} 3$ & -0.45717 & $5.23 \mathrm{E}-05$ & 0.006073 & -4.21395 & Down & adenylatecyclase 3 \\
\hline ILMN_1660086 & MYH11 & -0.45693 & 0.00135 & 0.028444 & -3.29091 & Down & myosin heavy chain 11 \\
\hline ILMN_1781149 & INMT & -0.45264 & 0.000222 & 0.012233 & -3.82134 & Down & indolethylamine N-methyltransferase \\
\hline ILMN_1671928 & PROS1 & -0.45214 & $5.66 \mathrm{E}-05$ & 0.006347 & -4.19283 & Down & protein $S$ \\
\hline ILMN_2377900 & MAP1B & -0.45172 & 0.000292 & 0.014028 & -3.74419 & Down & microtubule associated protein $1 \mathrm{~B}$ \\
\hline ILMN_1691127 & VTN & -0.45044 & $5.91 \mathrm{E}-06$ & 0.002933 & -4.76576 & Down & vitronectin \\
\hline ILMN_1701441 & LPAR1 & -0.45043 & $2.49 \mathrm{E}-05$ & 0.004816 & -4.40602 & Down & lysophosphatidic acid receptor 1 \\
\hline ILMN_1734190 & TCEAL3 & -0.45031 & 0.000148 & 0.010152 & -3.93406 & Down & transcription elongation factor A like 3 \\
\hline ILMN_1696749 & LMNA & -0.44963 & 7.46E-06 & 0.00295 & -4.70841 & Down & $\operatorname{lamin} \mathrm{A} / \mathrm{C}$ \\
\hline ILMN_3236825 & RAPGEF5 & -0.4488 & 0.00152 & 0.030129 & -3.25398 & Down & Rap guanine nucleotide exchange factor 5 \\
\hline ILMN_1791890 & SPON1 & -0.44793 & 0.000369 & 0.01532 & -3.67762 & Down & spondin 1 \\
\hline ILMN_1656951 & APCDD1 & -0.44608 & $5.84 \mathrm{E}-05$ & 0.006463 & -4.18452 & Down & APC down-regulated 1 \\
\hline ILMN_1723480 & BST2 & -0.44433 & $3.39 \mathrm{E}-05$ & 0.005189 & -4.32664 & Down & bone marrow stromal cell antigen 2 \\
\hline ILMN_1651429 & SELENOM & -0.44235 & 0.000729 & 0.021012 & -3.47803 & Down & selenoprotein $\mathrm{M}$ \\
\hline ILMN_1758164 & STC1 & -0.44235 & $5.34 \mathrm{E}-05$ & 0.006098 & -4.20849 & Down & stanniocalcin 1 \\
\hline ILMN_1728197 & CLDN5 & -0.44196 & 0.002297 & 0.037268 & -3.1232 & Down & claudin 5 \\
\hline ILMN_1663866 & TGFBI & -0.44055 & 0.000185 & 0.011135 & -3.87297 & Down & transforming growth factor beta induced \\
\hline ILMN_2057479 & EGFL6 & -0.44039 & 0.002923 & 0.042546 & -3.04508 & Down & EGF like domain multiple 6 \\
\hline
\end{tabular}




\begin{tabular}{|c|c|c|c|c|c|c|c|}
\hline ILMN_1784863 & CD36 & -0.43914 & 0.001443 & 0.029457 & -3.27014 & Down & CD36 molecule \\
\hline ILMN_1789492 & ZDHHC8 & -0.43853 & $1.97 \mathrm{E}-05$ & 0.004301 & -4.4659 & Down & $\begin{array}{l}\text { zinc finger DHHC-type containing } 8 \\
\text { cysteine rich secretory protein LCCL domain }\end{array}$ \\
\hline ILMN_1790689 & CRISPLD2 & -0.43782 & 0.000578 & 0.018974 & -3.54695 & Down & containing 2 \\
\hline ILMN_1795442 & LAMA4 & -0.43771 & $8.57 \mathrm{E}-05$ & 0.007637 & -4.08249 & Down & laminin subunit alpha 4 \\
\hline ILMN_1702501 & RPS6KA2 & -0.43678 & $2.81 \mathrm{E}-06$ & 0.002369 & -4.94542 & Down & ribosomal protein S6 kinase A2 \\
\hline ILMN_1671106 & GJA4 & -0.43644 & 0.000331 & 0.014708 & -3.70883 & Down & gap junction protein alpha 4 \\
\hline ILMN_1692058 & NDN & -0.43561 & $2.4 \mathrm{E}-05$ & 0.004755 & -4.41545 & Down & necdin, MAGE family member \\
\hline ILMN_1668629 & C4orf48 & -0.43536 & $3.2 \mathrm{E}-05$ & 0.005189 & -4.34205 & Down & chromosome 4 open reading frame 48 \\
\hline ILMN_1697448 & TXNIP & -0.43462 & 4.43E-05 & 0.005755 & -4.25718 & Down & thioredoxin interacting protein \\
\hline ILMN_1798360 & ACKR3 & -0.43355 & 0.000768 & 0.021647 & -3.46258 & Down & atypical chemokine receptor 3 \\
\hline ILMN_1671565 & RNASET2 & -0.43033 & 0.000961 & 0.024096 & -3.39507 & Down & ribonuclease $\mathrm{T} 2$ \\
\hline ILMN_1676449 & SLIT2 & -0.42992 & 0.000142 & 0.009889 & -3.94603 & Down & $\begin{array}{l}\text { slit guidance ligand } 2 \\
\text { pleckstrin homology like domain family A }\end{array}$ \\
\hline ILMN_1687978 & PHLDA1 & -0.42734 & $1.82 \mathrm{E}-05$ & 0.004138 & -4.48565 & Down & member 1 \\
\hline ILMN_1715991 & CAVIN2 & -0.42665 & 0.001128 & 0.025959 & -3.34614 & Down & caveolae associated protein 2 \\
\hline ILMN_2067656 & $\mathrm{CCND} 2$ & -0.42587 & 0.000216 & 0.012027 & -3.82966 & Down & $\begin{array}{c}\text { cyclin D2 } \\
\text { RHO family interacting cell polarization }\end{array}$ \\
\hline ILMN_1680037 & RIPOR1 & -0.42581 & $3.23 \mathrm{E}-06$ & 0.002557 & -4.91159 & Down & regulator 1 \\
\hline ILMN_1669409 & VSIG4 & -0.42564 & 0.000387 & 0.015721 & -3.66386 & Down & $\begin{array}{l}\text { V-set and immunoglobulin domain containing } 4 \\
\text { ADAM metallopeptidase with thrombospondin }\end{array}$ \\
\hline ILMN_1673566 & ADAMTS1 & -0.42513 & 0.000988 & 0.024354 & -3.3866 & Down & type 1 motif 1 \\
\hline ILMN_1709486 & SRPX & -0.42497 & 0.000723 & 0.020945 & -3.48076 & Down & sushi repeat containing protein $\mathrm{X}$-linked \\
\hline ILMN_2308849 & MYADM & -0.42477 & 0.00028 & 0.013713 & -3.75666 & Down & myeloid associated differentiation marker \\
\hline ILMN_1742534 & COL4A5 & -0.42458 & $3.49 \mathrm{E}-05$ & 0.005194 & -4.31961 & Down & collagen type IV alpha 5 chain \\
\hline ILMN_1662419 & COX7A1 & -0.42139 & 0.001898 & 0.033868 & -3.1842 & Down & cytochrome $\mathrm{c}$ oxidase subunit $7 \mathrm{~A} 1$ \\
\hline ILMN_1666894 & CSPG4 & -0.42081 & 0.000309 & 0.014326 & -3.72785 & Down & chondroitin sulfate proteoglycan 4 \\
\hline ILMN_1681679 & TSPO & -0.41878 & 0.000143 & 0.009968 & -3.9429 & Down & $\begin{array}{l}\text { translocator protein } \\
\text { 3'-phosphoadenosine 5'-phosphosulfate }\end{array}$ \\
\hline ILMN_2410929 & PAPSS2 & -0.41817 & 0.000199 & 0.011586 & -3.85207 & Down & $\begin{array}{l}\text { synthase } 2 \\
\text { HIG1 hypoxia inducible domain family member }\end{array}$ \\
\hline ILMN_1675936 & HIGD1B & -0.41805 & 0.002299 & 0.037268 & -3.12291 & Down & 1B \\
\hline ILMN_1800697 & LDB2 & -0.41769 & 0.000812 & 0.022284 & -3.44608 & Down & LIM domain binding 2 \\
\hline ILMN_1695959 & EVA1C & -0.41726 & $1.48 \mathrm{E}-06$ & 0.001955 & -5.09704 & Down & eva-1 homolog $C$ \\
\hline ILMN_1815700 & WNT3A & -0.41588 & 0.000685 & 0.020354 & -3.49693 & Down & Wnt family member $3 \mathrm{~A}$ \\
\hline ILMN_1672878 & $\mathrm{ABR}$ & -0.41554 & $1.42 \mathrm{E}-06$ & 0.001955 & -5.1066 & Down & $\begin{array}{l}\text { ABR activator of RhoGEF and GTPase } \\
\text { EGF containing fibulin extracellular matrix }\end{array}$ \\
\hline ILMN_1653203 & EFEMP2 & -0.41486 & $1.59 \mathrm{E}-05$ & 0.003762 & -4.52062 & Down & $\begin{array}{c}\text { protein } 2 \\
\text { CKLF like MARVEL transmembrane domain }\end{array}$ \\
\hline ILMN_1678353 & СMTM3 & -0.41405 & 3.33E-05 & 0.005189 & $\begin{array}{l}-4.33163 \\
-4.86121\end{array}$ & Down & $\begin{array}{c}\text { containing } 3 \\
\text { FERM, ARH/RhoGEF and pleckstrin domain } \\
\text { protein } 1\end{array}$ \\
\hline ILMN_1745963 & FOLR2 & -0.4129 & 0.002926 & 0.042546 & -3.04483 & Down & folate receptor beta \\
\hline ILMN_2189027 & LIPG & -0.41278 & 0.002567 & 0.039356 & -3.08744 & Down & lipase $\mathrm{G}$, endothelial type \\
\hline ILMN_1673352 & IFITM2 & -0.41277 & $1.45 \mathrm{E}-05$ & 0.003584 & -4.54291 & Down & interferon induced transmembrane protein 2 \\
\hline ILMN_1814327 & AGTR1 & -0.4127 & 0.003348 & 0.045512 & -3.00053 & Down & angiotensin II receptor type 1 \\
\hline ILMN_1727532 & OLFML3 & -0.41123 & 0.000299 & 0.014133 & -3.73746 & Down & olfactomedin like 3 \\
\hline ILMN_1764964 & IFNGR2 & -0.41058 & 0.000123 & 0.009352 & -3.98429 & Down & $\begin{array}{l}\text { interferon gamma receptor } 2 \\
\text { NDUFA4 mitochondrial complex associated }\end{array}$ \\
\hline ILMN_1756573 & NDUFA4L2 & -0.40838 & 0.001643 & 0.031536 & -3.22967 & Down & like 2 \\
\hline ILMN_1653466 & HES4 & -0.40777 & 0.000111 & 0.008868 & -4.013 & Down & hes family bHLH transcription factor 4 \\
\hline ILMN_2396875 & IGFBP3 & -0.40708 & 0.001143 & 0.026058 & -3.34212 & own & insulin like growth factor binding protein 3 \\
\hline
\end{tabular}




\begin{tabular}{|c|c|c|c|c|c|c|c|}
\hline ILMN_2038775 & TUBB2A & -0.40565 & 0.001946 & 0.03431 & -3.17614 & Down & tubulin beta $2 \mathrm{~A}$ class IIa \\
\hline ILMN_1812031 & PALM & -0.40551 & $1.37 \mathrm{E}-05$ & 0.003478 & -4.55698 & Down & paralemmin \\
\hline ILMN_1709307 & GPSM1 & -0.4053 & $3.66 \mathrm{E}-05$ & 0.005267 & -4.30712 & Down & G protein signaling modulator 1 \\
\hline ILMN_3246214 & B4GAT1 & -0.40496 & $3.87 \mathrm{E}-07$ & 0.001058 & -5.40781 & Down & beta-1,4-glucuronyltransferase 1 \\
\hline ILMN_1802411 & ITGA1 & -0.4038 & $3.16 \mathrm{E}-05$ & 0.005189 & -4.34541 & Down & integrin subunit alpha 1 \\
\hline ILMN_1714861 & CD68 & -0.40235 & 0.001299 & 0.027871 & -3.30268 & Down & $\begin{array}{l}\text { CD68 molecule } \\
\text { pleckstrin homology like domain family B }\end{array}$ \\
\hline ILMN_1666819 & PHLDB1 & -0.40159 & $2.35 \mathrm{E}-05$ & 0.004738 & -4.42152 & Down & member 1 \\
\hline ILMN_1723481 & CHST3 & -0.40156 & $5.39 \mathrm{E}-06$ & 0.002879 & -4.78828 & Down & carbohydrate sulfotransferase 3 \\
\hline ILMN_1724994 & COL4A2 & -0.40135 & 0.000401 & 0.01601 & -3.65332 & Down & $\begin{array}{l}\text { collagen type IV alpha } 2 \text { chain } \\
\text { potassium two pore domain channel subfamily }\end{array}$ \\
\hline ILMN_1768483 & KCNK3 & -0.40133 & 4.77E-05 & 0.005826 & -4.23792 & Down & $\mathrm{K}$ member 3 \\
\hline ILMN_1717934 & SYT11 & -0.40115 & $2.98 \mathrm{E}-05$ & 0.005073 & -4.35983 & Down & synaptotagmin 11 \\
\hline ILMN_1812968 & SOX18 & -0.40033 & 0.000526 & 0.018141 & -3.57485 & Down & SRY-box transcription factor 18 \\
\hline ILMN_2173611 & MT1E & -0.39988 & 0.000353 & 0.015039 & -3.69035 & Down & metallothionein $1 \mathrm{E}$ \\
\hline ILMN_1668283 & HYAL2 & -0.39864 & 0.000646 & 0.019821 & -3.51392 & Down & hyaluronidase 2 \\
\hline ILMN_1757440 & DIPK1B & -0.39796 & 0.00033 & 0.014704 & -3.70918 & Down & divergent protein kinase domain 1B \\
\hline ILMN_1773059 & ADGRA2 & -0.39739 & 0.000911 & 0.023503 & -3.41136 & Down & adhesion $\mathrm{G}$ protein-coupled receptor A2 \\
\hline ILMN_1795429 & VCL & -0.39693 & 0.000348 & 0.014991 & -3.69401 & Down & vinculin \\
\hline ILMN_1789733 & CLIP3 & -0.39665 & $1.53 \mathrm{E}-05$ & 0.00373 & -4.53031 & Down & CAP-Gly domain containing linker protein 3 \\
\hline ILMN_1675062 & MYL9 & -0.39519 & 0.001559 & 0.030619 & -3.24612 & Down & myosin light chain 9 \\
\hline ILMN_1711566 & TIMP1 & -0.39465 & 0.001568 & 0.030761 & -3.24426 & Down & TIMP metallopeptidase inhibitor 1 \\
\hline ILMN_1682781 & TEAD2 & -0.39462 & 2.27E-05 & 0.004675 & -4.42977 & Down & TEA domain transcription factor 2 \\
\hline ILMN_1806733 & COL18A1 & -0.39225 & 0.000595 & 0.019227 & -3.53859 & Down & collagen type XVIII alpha 1 chain \\
\hline ILMN_1769091 & PRCP & -0.39168 & 0.000281 & 0.013751 & -3.75557 & Down & prolylcarboxypeptidase \\
\hline ILMN_1691376 & JAG1 & -0.39137 & 0.000108 & 0.008727 & -4.02057 & Down & $\begin{array}{l}\quad \text { jagged canonical Notch ligand } 1 \\
\text { RNA binding protein, mRNA processing factor }\end{array}$ \\
\hline ILMN_1808238 & RBPMS2 & -0.39047 & $2.27 \mathrm{E}-05$ & 0.004675 & -4.43015 & Down & procollagen-lysine,2-oxoglutarate 5- \\
\hline & & & & & & & \\
\hline ILMN_1755657 & RASIP1 & -0.38985 & 0.00111 & 0.025736 & -3.35121 & Down & Ras interacting protein 1 \\
\hline ILMN_1754795 & FAT1 & -0.38928 & 0.000803 & 0.02216 & -3.44913 & Down & $\begin{array}{l}\text { FAT atypical cadherin } 1 \\
\text { atypical chemokine receptor } 1 \text { (Duffy blood }\end{array}$ \\
\hline ILMN_1723684 & ACKR1 & -0.38904 & 0.000258 & 0.013173 & -3.77982 & Down & group) \\
\hline ILMN_1763640 & NCKAP5L & -0.38828 & 4.47E-05 & 0.005755 & -4.25481 & Down & NCK associated protein 5 like \\
\hline ILMN_2066151 & TEK & -0.38809 & 0.001131 & 0.025976 & -3.34543 & Down & TEK receptor tyrosine kinase \\
\hline ILMN_1730995 & AFAP1L2 & -0.38806 & $6.29 \mathrm{E}-05$ & 0.006657 & -4.16513 & Down & actin filament associated protein 1 like 2 \\
\hline ILMN_1676846 & ABCE1 & -0.38772 & 0.002141 & 0.035854 & -3.14571 & Down & ATP binding cassette subfamily E member 1 \\
\hline ILMN_2306540 & PDE9A & -0.38716 & 0.000255 & 0.013135 & -3.78258 & Down & phosphodiesterase 9A \\
\hline ILMN_1756920 & ADAM15 & -0.38698 & $2.31 \mathrm{E}-05$ & 0.004723 & -4.4258 & Down & ADAM metallopeptidase domain 15 \\
\hline ILMN_1667460 & SULF2 & -0.38575 & 0.000356 & 0.015084 & -3.68742 & Down & sulfatase 2 \\
\hline ILMN_1778681 & EBF1 & -0.38542 & 0.000387 & 0.015721 & -3.66397 & Down & EBF transcription factor 1 \\
\hline ILMN_1810852 & LAMC1 & -0.38297 & 0.000107 & 0.008689 & -4.02291 & Down & laminin subunit gamma 1 \\
\hline ILMN_1723123 & FGFR3 & -0.38138 & 0.000151 & 0.010247 & -3.92785 & Down & fibroblast growth factor receptor 3 \\
\hline ILMN_1741632 & RAB3IL1 & -0.381 & $1.3 \mathrm{E}-05$ & 0.003464 & -4.57014 & Down & RAB3A interacting protein like 1 \\
\hline ILMN_2230025 & PDLIM3 & -0.381 & 0.000642 & 0.019792 & -3.51588 & Down & PDZ and LIM domain 3 \\
\hline ILMN_1772612 & ANGPTL2 & -0.37902 & $2.69 \mathrm{E}-05$ & 0.004861 & -4.38663 & Down & angiopoietin like 2 \\
\hline
\end{tabular}




\begin{tabular}{|c|c|c|c|c|c|c|c|}
\hline ILMN_1810844 & RARRES2 & -0.37881 & 0.000884 & 0.023267 & -3.42025 & Down & retinoic acid receptor responder 2 \\
\hline ILMN_1738816 & FOXO1 & -0.37837 & 0.000525 & 0.018141 & -3.57509 & Down & forkhead box $\mathrm{O} 1$ \\
\hline ILMN_1689953 & CD81 & -0.37702 & $1.74 \mathrm{E}-07$ & 0.000867 & -5.58795 & Down & CD81 molecule \\
\hline ILMN_1651950 & TPST1 & -0.37597 & $3.72 \mathrm{E}-05$ & 0.005297 & -4.30272 & Down & tyrosylproteinsulfotransferase 1 \\
\hline ILMN_1692731 & TTYH3 & -0.37535 & $3.37 \mathrm{E}-05$ & 0.005189 & -4.32847 & Down & tweety family member 3 \\
\hline ILMN_1658835 & CAV2 & -0.37448 & 0.001154 & 0.026156 & -3.33932 & Down & caveolin 2 \\
\hline ILMN_1680453 & ITM2C & -0.37416 & 0.000588 & 0.019112 & -3.54215 & Down & integral membrane protein $2 \mathrm{C}$ \\
\hline ILMN_1702835 & SH3BGRL & -0.37249 & 0.000342 & 0.01488 & -3.69952 & Down & $\mathrm{SH} 3$ domain binding glutamate rich protein like \\
\hline ILMN_1732923 & SIPA1L2 & -0.37207 & 0.000758 & 0.021475 & -3.46637 & Down & signal induced proliferation associated 1 like 2 \\
\hline ILMN_1797009 & F3 & -0.37136 & 0.00032 & 0.014545 & -3.71818 & Down & $\begin{array}{l}\text { coagulation factor III, tissue factor } \\
\text { phosphatidylinositol glycan anchor biosynthesis }\end{array}$ \\
\hline ILMN_1738263 & PIGU & -0.37121 & 0.00019 & 0.011345 & -3.86457 & Down & class $\mathrm{U}$ \\
\hline ILMN_1739946 & VKORC1 & -0.3684 & 0.000138 & 0.009805 & -3.95412 & Down & $\begin{array}{l}\text { vitamin K epoxide reductase complex subunit } 1 \\
\text { DIMT1 rRNAmethyltransferase and ribosome }\end{array}$ \\
\hline ILMN_1803312 & DIMT1 & -0.36765 & $2.11 \mathrm{E}-05$ & 0.004531 & -4.44861 & Down & maturation factor \\
\hline ILMN_2089752 & ALKAL2 & -0.3669 & 0.003884 & 0.049065 & -2.95119 & Down & ALK and LTK ligand 2 \\
\hline ILMN_1729563 & UGDH & -0.36578 & 0.00195 & 0.034354 & -3.1755 & Down & UDP-glucose 6-dehydrogenase \\
\hline ILMN_1695290 & FERMT2 & -0.36562 & $8.34 \mathrm{E}-06$ & 0.00295 & -4.68113 & Down & fermitin family member 2 \\
\hline ILMN_1748473 & GIMAP4 & -0.3654 & 0.000178 & 0.010961 & -3.88275 & Down & GTPase, IMAP family member 4 \\
\hline ILMN_3242038 & GPX8 & -0.36483 & 0.000302 & 0.014133 & -3.73508 & Down & glutathione peroxidase 8 (putative) \\
\hline ILMN_1781256 & LEFTY2 & -0.36409 & 0.001663 & 0.031713 & -3.2258 & Down & left-right determination factor 2 \\
\hline ILMN_1718607 & TSPAN4 & -0.36243 & 0.000121 & 0.009241 & -3.98826 & Down & tetraspanin 4 \\
\hline ILMN_1653028 & COL4A1 & -0.36243 & 0.000251 & 0.013046 & -3.78705 & Down & collagen type IV alpha 1 chain \\
\hline ILMN_1806403 & RASL12 & -0.3617 & 0.000182 & 0.011037 & -3.87729 & Down & RAS like family 12 \\
\hline ILMN_1770338 & TM4SF1 & -0.36154 & 0.002035 & 0.035083 & -3.16202 & Down & transmembrane $4 \mathrm{~L}$ six family member 1 \\
\hline ILMN_1757552 & CAVIN1 & -0.36036 & $1.87 \mathrm{E}-05$ & 0.004187 & -4.47961 & Down & caveolae associated protein 1 \\
\hline ILMN_2148944 & $\mathrm{ADCY} 4$ & -0.36032 & 0.002039 & 0.035103 & -3.16139 & Down & adenylatecyclase 4 \\
\hline ILMN_2346997 & RAB23 & -0.36006 & $4.72 \mathrm{E}-05$ & 0.005816 & -4.241 & Down & RAB23, member RAS oncogene family \\
\hline ILMN_1803429 & CD44 & -0.35802 & 0.001453 & 0.029623 & -3.268 & Down & CD44 molecule (Indian blood group) \\
\hline ILMN_1757845 & SPIRE1 & -0.35788 & 0.000136 & 0.009769 & -3.9577 & Down & spire type actin nucleation factor 1 \\
\hline ILMN_2063168 & MALL & -0.35738 & 0.000348 & 0.014991 & -3.69453 & Down & mal, $\mathrm{T}$ cell differentiation protein like \\
\hline ILMN_1794492 & HOXC6 & -0.35691 & $2.08 \mathrm{E}-05$ & 0.004478 & -4.45271 & Down & homeobox C6 \\
\hline ILMN_2089073 & АТР9A & -0.35669 & 0.000323 & 0.014545 & -3.71549 & Down & $\begin{array}{l}\text { ATPase phospholipid transporting 9A (putative) } \\
\text { heat shock protein family A (Hsp70) member }\end{array}$ \\
\hline ILMN_1676897 & HSPA12B & -0.35655 & 0.001255 & 0.027297 & -3.31351 & Down & $12 \mathrm{~B}$ \\
\hline ILMN_1720158 & ETS2 & -0.35607 & $1.88 \mathrm{E}-05$ & 0.004187 & -4.47844 & Down & ETS proto-oncogene 2, transcription factor \\
\hline ILMN_1767448 & LHFPL6 & -0.35579 & 0.000815 & 0.022307 & -3.44483 & Down & LHFPL tetraspan subfamily member 6 \\
\hline ILMN_3238560 & IFI27L2 & -0.35573 & $2.7 \mathrm{E}-05$ & 0.004861 & -4.38599 & Down & interferon alpha inducible protein 27 like 2 \\
\hline ILMN_1784871 & FASN & -0.35492 & $1.19 \mathrm{E}-06$ & 0.001926 & -5.14833 & Down & fatty acid synthase \\
\hline ILMN_1680874 & TUBB2B & -0.35438 & $2.27 \mathrm{E}-05$ & 0.004675 & -4.42951 & Down & tubulin beta $2 \mathrm{~B}$ class IIb \\
\hline ILMN_2081682 & SMAP2 & -0.35276 & $6.18 \mathrm{E}-05$ & 0.006575 & -4.16954 & Down & small ArfGAP2 \\
\hline ILMN_1774982 & CDC42EP5 & -0.35271 & $4.66 \mathrm{E}-05$ & 0.005784 & -4.24433 & Down & CDC42 effector protein 5 \\
\hline ILMN_1788019 & LAMA2 & -0.35245 & 0.00276 & 0.041163 & -3.0638 & Down & laminin subunit alpha 2 \\
\hline ILMN_1783276 & NEXN & -0.35153 & 0.000177 & 0.010947 & -3.88438 & Down & nexilin F-actin binding protein \\
\hline ILMN_1676088 & MSRB3 & -0.35012 & 0.000365 & 0.015248 & -3.68065 & Down & methionine sulfoxidereductase B3 \\
\hline
\end{tabular}




\begin{tabular}{|c|c|c|c|c|c|c|c|}
\hline ILMN_1795183 & RNASE1 & -0.34959 & 0.003183 & 0.044326 & -3.01723 & Down & ribonuclease A family member 1 , pancreatic \\
\hline ILMN_1704537 & PHGDH & -0.34957 & $8.55 \mathrm{E}-05$ & 0.007633 & -4.08329 & Down & $\begin{array}{l}\text { phosphoglycerate dehydrogenase } \\
\text { ADAM metallopeptidase with thrombospondin }\end{array}$ \\
\hline ILMN_1805543 & ADAMTS9 & -0.34922 & 0.001219 & 0.026853 & -3.32252 & Down & type 1 motif 9 \\
\hline ILMN_2127605 & LRP3 & -0.3484 & $9.59 \mathrm{E}-07$ & 0.001775 & -5.19866 & Down & LDL receptor related protein 3 \\
\hline ILMN_2410523 & DDR2 & -0.34789 & 0.000108 & 0.008756 & -4.019 & Down & $\begin{array}{l}\text { discoidin domain receptor tyrosine kinase } 2 \\
\text { transforming growth factor beta } 1 \text { induced }\end{array}$ \\
\hline ILMN_2389876 & TGFB1I1 & -0.34786 & 0.000225 & 0.012343 & -3.81789 & Down & transcript 1 \\
\hline ILMN_3241758 & POTEF & -0.34764 & 0.001247 & 0.027181 & -3.31554 & Down & POTE ankyrin domain family member $F$ \\
\hline ILMN_1770454 & AGRN & -0.34742 & 0.00053 & 0.018229 & -3.57218 & Down & agrin \\
\hline ILMN_1752249 & PIEZO1 & -0.34641 & 0.000798 & 0.022091 & -3.45127 & Down & $\begin{array}{l}\text { piezo type mechanosensitive ion channel } \\
\text { component } 1\end{array}$ \\
\hline ILMN_1663080 & LFNG & -0.34636 & $5.26 \mathrm{E}-05$ & 0.006073 & -4.21211 & Down & $\begin{array}{l}\text { acetylglucosaminyltransferase } \\
\text { ald }\end{array}$ \\
\hline ILMN_1672389 & CRYZ & -0.3461 & 0.000537 & 0.018298 & -3.56835 & Down & crystallin zeta \\
\hline ILMN_1776724 & LYPD6 & -0.34584 & $1.34 \mathrm{E}-05$ & 0.00347 & -4.56326 & Down & LY6/PLAUR domain containing 6 \\
\hline ILMN_1777397 & MSX1 & -0.34534 & 0.000377 & 0.015431 & -3.67168 & Down & mshhomeobox 1 \\
\hline ILMN_1783593 & CCL13 & -0.34534 & 0.001155 & 0.026177 & -3.33892 & Down & C-C motif chemokine ligand 13 \\
\hline ILMN_2398159 & DKK3 & -0.34528 & 0.003364 & 0.045581 & -2.99896 & Down & dickkopf WNT signaling pathway inhibitor 3 \\
\hline ILMN_1743367 & FZD4 & -0.34522 & 0.000443 & 0.016957 & -3.62449 & Down & $\begin{array}{c}\text { frizzled class receptor } 4 \\
\text { 6-phosphofructo-2-kinase/fructose-2.6- }\end{array}$ \\
\hline ILMN_2186061 & PFKFB3 & -0.34512 & 0.000537 & 0.018294 & -3.56884 & Down & biphosphatase 3 \\
\hline ILMN_1662340 & ZNF358 & -0.34471 & $3.09 \mathrm{E}-06$ & 0.002517 & -4.9227 & Down & zinc finger protein 358 \\
\hline ILMN_1778991 & NFIB & -0.34285 & 0.001613 & 0.031272 & -3.23532 & Down & nuclear factor I B \\
\hline ILMN_1812926 & ANTXR2 & -0.3415 & $5.68 \mathrm{E}-05$ & 0.006347 & -4.19218 & Down & ANTXR cell adhesion molecule 2 \\
\hline ILMN_1657632 & TMEM35B & -0.33999 & $8.22 \mathrm{E}-05$ & 0.007511 & -4.09378 & Down & transmembrane protein $35 \mathrm{~B}$ \\
\hline ILMN_1778226 & EXTL3 & -0.33995 & 0.001652 & 0.03162 & -3.22796 & Down & exostosin like glycosyltransferase 3 \\
\hline ILMN_1782938 & SLC16A10 & -0.33976 & 0.002898 & 0.042362 & -3.04796 & Down & solute carrier family 16 member 10 \\
\hline ILMN_2193325 & MMP23B & -0.33959 & 0.000713 & 0.020805 & -3.48474 & Down & matrix metallopeptidase 23B \\
\hline ILMN_1739496 & PRRX1 & -0.33948 & 0.000146 & 0.010103 & -3.93722 & Down & paired related homeobox 1 \\
\hline ILMN_1865764 & ZMAT3 & -0.33777 & $1.18 \mathrm{E}-06$ & 0.001926 & -5.14964 & Down & $\begin{array}{l}\text { zinc finger matrin-type } 3 \\
\text { calcium/calmodulin dependent protein kinase II }\end{array}$ \\
\hline ILMN_1794863 & CAMK2N1 & -0.33759 & 0.001093 & 0.025566 & -3.35581 & Down & $\begin{array}{c}\text { inhibitor } 1 \\
\text { EGF containing fibulin extracellular matrix }\end{array}$ \\
\hline ILMN_1735877 & EFEMPI & -0.33701 & 0.003 & 0.043103 & -3.03665 & Down & protein 1 \\
\hline ILMN_2120247 & SLC2A10 & -0.33689 & 0.001012 & 0.02466 & -3.37924 & Down & $\begin{array}{l}\text { solute carrier family } 2 \text { member } 10 \\
\text { Rac/Cdc42 guanine nucleotide exchange factor }\end{array}$ \\
\hline ILMN_1803423 & ARHGEF6 & -0.33673 & 0.001997 & 0.034749 & -3.16805 & Down & 6 \\
\hline ILMN_2201533 & TMEM256 & -0.3363 & 9.84E-05 & 0.008273 & -4.04548 & Down & $\begin{array}{c}\text { transmembrane protein } 256 \\
\text { CKLF like MARVEL transmembrane }\end{array}$ \\
\hline ILMN_1698934 & CMTM7 & -0.33562 & $6.8 \mathrm{E}-05$ & 0.006927 & -4.14452 & Down & containing 7 \\
\hline ILMN_1697409 & TNFRSF14 & -0.33559 & 0.000266 & 0.013333 & -3.77075 & Down & $\begin{array}{l}\text { TNF receptor superfamily member } 14 \\
\text { glucose-fructose oxidoreductase domain }\end{array}$ \\
\hline ILMN_1778240 & GFOD1 & -0.33518 & 0.00062 & 0.019425 & -3.52642 & Down & containing 1 \\
\hline ILMN_1743373 & DLL1 & -0.3346 & 0.000177 & 0.010936 & -3.88539 & Down & delta like canonical Notch ligand 1 \\
\hline ILMN_2216582 & LYL1 & -0.3343 & 0.000484 & 0.017744 & -3.59922 & Down & LYL1 basic helix-loop-helix family member \\
\hline ILMN_1765641 & SEMA3A & -0.33427 & 0.000485 & 0.017744 & -3.59859 & Down & semaphorin $3 \mathrm{~A}$ \\
\hline ILMN_1890614 & INKA2 & -0.33389 & 7.18E-06 & 0.00295 & -4.71805 & Down & inka box actin regulator 2 \\
\hline ILMN_2095133 & SPTAN1 & -0.33345 & $7.54 \mathrm{E}-05$ & 0.007229 & -4.11685 & Down & spectrin alpha, non-erythrocytic 1 \\
\hline ILMN_1783681 & MRPL34 & -0.33294 & 0.001535 & 0.030319 & -3.25087 & Down & mitochondrial ribosomal protein $\mathrm{L} 34$ \\
\hline ILMN_1705302 & FCGRT & -0.33153 & 0.00135 & 0.028444 & -3.29084 & Down & Fc fragment of IgG receptor and transporter \\
\hline ILMN_1682738 & SMAD3 & -0.33045 & $6.58 \mathrm{E}-05$ & 0.006811 & -4.15297 & Down & SMAD family member 3 \\
\hline
\end{tabular}




\begin{tabular}{|c|c|c|c|c|c|c|c|}
\hline ILMN_2059535 & PPM1F & -0.3304 & 0.001065 & 0.025246 & -3.36391 & Down & protein phosphatase, $\mathrm{Mg} 2+/ \mathrm{Mn} 2+$ dependent $1 \mathrm{~F}$ \\
\hline ILMN_1790953 & $\mathrm{TBCB}$ & -0.3301 & $2.21 \mathrm{E}-05$ & 0.004675 & -4.43726 & Down & tubulin folding cofactor B \\
\hline ILMN_1764788 & TNFRSF1B & -0.32976 & 0.003169 & 0.044269 & -3.0186 & Down & TNF receptor superfamily member $1 \mathrm{~B}$ \\
\hline ILMN_1754660 & $\mathrm{ZCCHC} 24$ & -0.32898 & 0.000101 & 0.008387 & -4.03815 & Down & zinc finger CCHC-type containing 24 \\
\hline ILMN_2252309 & DPP7 & -0.32892 & 0.001126 & 0.025921 & -3.34674 & Down & dipeptidyl peptidase 7 \\
\hline ILMN_1674160 & BIN1 & -0.32855 & 0.000214 & 0.012004 & -3.83144 & Down & bridging integrator 1 \\
\hline ILMN_1675656 & PPFIBP2 & -0.32771 & 0.00043 & 0.016689 & -3.63326 & Down & PPFIA binding protein 2 \\
\hline ILMN_1728512 & YWHAH & -0.32748 & $6.04 \mathrm{E}-05$ & 0.006541 & -4.17595 & Down & $\begin{array}{l}\text { tyrosine 3-monooxygenase/tryptophan 5- } \\
\text { monooxygenase activation protein eta }\end{array}$ \\
\hline ILMN_1789171 & EEF2K & -0.32709 & $1.05 \mathrm{E}-05$ & 0.003154 & -4.62387 & Down & eukaryotic elongation factor 2 kinase \\
\hline ILMN_1680973 & FOXF1 & -0.3269 & 0.000111 & 0.008868 & -4.01194 & Down & forkhead box F1 \\
\hline ILMN_1805750 & IFITM3 & -0.3253 & 0.000765 & 0.021605 & -3.46392 & Down & interferon induced transmembrane protein 3 \\
\hline ILMN_2298365 & PPP2R2B & -0.3252 & 0.000614 & 0.019397 & -3.52901 & Down & protein phosphatase 2 regulatory subunit Bbeta \\
\hline ILMN_1814194 & TCF4 & -0.32479 & 0.00114 & 0.026051 & -3.34287 & Down & transcription factor 4 \\
\hline ILMN_1769520 & UBE2L6 & -0.32451 & 0.001765 & 0.032784 & -3.20703 & Down & ubiquitin conjugating enzyme E2 L6 \\
\hline ILMN_1730487 & CALD1 & -0.32449 & 0.000631 & 0.019631 & -3.52115 & Down & caldesmon 1 \\
\hline ILMN_1804929 & OXTR & -0.32448 & 0.000803 & 0.02216 & -3.44941 & Down & oxytocin receptor \\
\hline ILMN_2174127 & DCBLD2 & -0.32399 & $6.83 \mathrm{E}-06$ & 0.00295 & -4.73008 & Down & discoidin, CUB and LCCL domain containing 2 \\
\hline ILMN_1703477 & ARHGEF2 & -0.32314 & $7.85 \mathrm{E}-05$ & 0.007364 & -4.10614 & Down & Rho/Rac guanine nucleotide exchange factor 2 \\
\hline ILMN_1804277 & SPRED1 & -0.32305 & 0.002215 & 0.036485 & -3.13485 & Down & sprouty related EVH1 domain containing 1 \\
\hline ILMN_1712075 & SYNM & -0.32231 & 0.002466 & 0.038662 & -3.10033 & Down & synemin \\
\hline ILMN_1770290 & CNN2 & -0.3223 & 0.000584 & 0.01904 & -3.54398 & Down & calponin 2 \\
\hline ILMN_2064725 & METTL7B & -0.32199 & 0.000739 & 0.021238 & -3.474 & Down & methyltransferase like 7B \\
\hline ILMN_2343097 & NCALD & -0.32174 & $5.26 \mathrm{E}-06$ & 0.002879 & -4.7939 & Down & neurocalcin delta \\
\hline ILMN_1676515 & IMPDH1 & -0.32151 & $2.8 \mathrm{E}-06$ & 0.002369 & -4.94609 & Down & inosine monophosphate dehydrogenase 1 \\
\hline ILMN_1685540 & SHROOM3 & -0.32144 & $9.41 \mathrm{E}-05$ & 0.008052 & -4.05753 & Down & shroom family member 3 \\
\hline ILMN_1839019 & LPP & -0.32071 & 0.000295 & 0.01409 & -3.74125 & Down & partner in lipoma \\
\hline ILMN_1747223 & FRYL & -0.32039 & 0.000312 & 0.014386 & -3.72536 & Down & $\begin{array}{c}\text { FRY like transcription coactivator } \\
\text { late endosomal/lysosomal adaptor, MAPK and }\end{array}$ \\
\hline ILMN_1779735 & LAMTOR4 & -0.32032 & 0.001384 & 0.028811 & -3.28315 & Down & MTOR activator 4 \\
\hline ILMN_2316386 & GPBAR1 & -0.31949 & 0.000134 & 0.009736 & -3.96066 & Down & G protein-coupled bile acid receptor 1 \\
\hline ILMN_1810559 & RHOQ & -0.31922 & $9.79 \mathrm{E}-05$ & 0.008252 & -4.04665 & Down & ras homolog family member Q \\
\hline ILMN_1804498 & BRAT1 & -0.31861 & 0.000157 & 0.010362 & -3.91859 & Down & BRCA1 associated ATM activator 1 \\
\hline ILMN_1785618 & SMTN & -0.31794 & 0.000103 & 0.008513 & -4.03259 & Down & smoothelin \\
\hline ILMN_1778444 & FKBP5 & -0.31765 & 0.003284 & 0.045007 & -3.00692 & Down & FKBP prolylisomerase 5 \\
\hline ILMN_1704154 & TNFRSF19 & -0.31706 & 0.000322 & 0.014545 & -3.71667 & Down & TNF receptor superfamily member 19 \\
\hline ILMN_2104141 & FGD5 & -0.317 & 0.000237 & 0.012746 & -3.80302 & Down & FYVE, RhoGEF and PH domain containing 5 \\
\hline ILMN_2149226 & CAV1 & -0.31687 & 0.002907 & 0.042449 & -3.04697 & Down & $\begin{array}{c}\text { caveolin } 1 \\
\text { ral guanine nucleotide dissociation stimulator }\end{array}$ \\
\hline ILMN_1654398 & RGL1 & -0.31678 & 0.000409 & 0.016197 & -3.64795 & Down & like 1 \\
\hline ILMN_3307892 & PARVA & -0.31677 & $1.15 \mathrm{E}-05$ & 0.003353 & -4.60138 & Down & parvin alpha \\
\hline ILMN_3241262 & PABPC4L & -0.3167 & 0.001528 & 0.030233 & -3.2524 & Down & poly(A) binding protein cytoplasmic 4 like \\
\hline ILMN_1730229 & CGNL1 & -0.31553 & 0.000937 & 0.02378 & -3.40267 & Down & cingulin like 1 \\
\hline ILMN_1779071 & FEZ1 & -0.31546 & $3.78 \mathrm{E}-05$ & 0.005357 & -4.29902 & Down & fasciculation and elongation protein zeta 1 \\
\hline ILMN_1775330 & CCDC9B & -0.31511 & $8.78 \mathrm{E}-05$ & 0.007748 & -4.07615 & Down & coiled-coil domain containing 9B \\
\hline
\end{tabular}




\begin{tabular}{|c|c|c|c|c|c|c|c|}
\hline ILMN_1701204 & VEGFC & -0.31459 & 0.000186 & 0.011194 & -3.87116 & Down & vascular endothelial growth factor $\mathrm{C}$ \\
\hline ILMN_1777881 & TSPAN17 & -0.31456 & 4.57E-05 & 0.005773 & -4.24941 & Down & tetraspanin 17 \\
\hline ILMN_1677200 & CYFIP2 & -0.31396 & 0.0005 & 0.017901 & -3.58965 & Down & cytoplasmic FMR1 interacting protein 2 \\
\hline ILMN_2056032 & CD99 & -0.3134 & 0.001609 & 0.031251 & -3.23623 & Down & CD99 molecule (Xg blood group) \\
\hline ILMN_1752591 & LEPROTL1 & -0.3128 & 0.001734 & 0.032382 & -3.21268 & Down & leptin receptor overlapping transcript like 1 \\
\hline ILMN_1757338 & PLSCR4 & -0.31123 & 0.000327 & 0.014624 & -3.7118 & Down & phospholipid scramblase 4 \\
\hline ILMN_3245564 & ARHGAP44 & -0.3111 & 4.92E-05 & 0.005917 & -4.22987 & Down & Rho GTPase activating protein 44 \\
\hline ILMN_1699980 & TSPAN18 & -0.31001 & 0.000286 & 0.013944 & -3.74989 & Down & tetraspanin 18 \\
\hline ILMN_3232894 & CNRIP1 & -0.30921 & 0.00187 & 0.033574 & -3.18876 & Down & cannabinoid receptor interacting protein 1 \\
\hline ILMN_1771800 & PRKCA & -0.30913 & $3.17 \mathrm{E}-05$ & 0.005189 & -4.34465 & Down & protein kinase $\mathrm{C}$ alpha \\
\hline ILMN_2397954 & PARP3 & -0.30902 & $1.52 \mathrm{E}-06$ & 0.001955 & -5.09076 & Down & poly(ADP-ribose) polymerase family member 3 \\
\hline ILMN_1808777 & EHD2 & -0.30827 & 0.0001 & 0.008353 & -4.04098 & Down & EH domain containing 2 \\
\hline ILMN_1758128 & CYGB & -0.30813 & $3.22 \mathrm{E}-05$ & 0.005189 & -4.34001 & Down & $\begin{array}{c}\text { cytoglobin } \\
\text { phosphatidylinositol-4-phosphate 5-kinase type }\end{array}$ \\
\hline ILMN_1668514 & PIP5K1C & -0.30797 & 0.000323 & 0.014545 & -3.71537 & Down & 1 gamma \\
\hline ILMN_3236344 & BMS1P4 & -0.30771 & 0.000204 & 0.011804 & -3.84512 & Down & BMS1 pseudogene 4 \\
\hline ILMN_1708743 & NT5DC2 & -0.30746 & 7.44E-05 & 0.007229 & -4.12035 & Down & 5'-nucleotidase domain containing 2 \\
\hline ILMN_1760493 & LIMS2 & -0.30721 & 0.000139 & 0.00984 & -3.95143 & Down & LIM zinc finger domain containing 2 \\
\hline ILMN_1736670 & PPP1R3C & -0.30647 & 0.001626 & 0.031392 & -3.23287 & Down & protein phosphatase 1 regulatory subunit $3 \mathrm{C}$ \\
\hline ILMN_1671295 & $\mathrm{CCDC} 3$ & -0.3059 & 0.001513 & 0.030094 & -3.25547 & Down & coiled-coil domain containing 3 \\
\hline ILMN_2102330 & COL8A2 & -0.3057 & 0.000112 & 0.008882 & -4.01107 & Down & collagen type VIII alpha 2 chain \\
\hline ILMN_2359945 & CES1 & -0.30559 & 0.00016 & 0.010366 & -3.91273 & Down & carboxylesterase 1 \\
\hline ILMN_1780057 & RENBP & -0.3052 & 0.000155 & 0.010361 & -3.92141 & Down & renin binding protein \\
\hline ILMN_1658847 & NRARP & -0.30411 & 0.000766 & 0.021608 & -3.46347 & Down & NOTCH regulated ankyrin repeat protein \\
\hline ILMN_1718303 & NECTIN2 & -0.30407 & 0.000344 & 0.014909 & -3.69776 & Down & nectin cell adhesion molecule 2 \\
\hline ILMN_1764410 & GUCD1 & -0.30401 & 0.001226 & 0.026935 & -3.3206 & Down & guanylylcyclase domain containing 1 \\
\hline ILMN_1691717 & RHBDF2 & -0.30355 & 0.000467 & 0.017456 & -3.60933 & Down & rhomboid 5 homolog 2 \\
\hline ILMN_1766675 & CDH6 & -0.30348 & $5.65 \mathrm{E}-05$ & 0.006347 & -4.19354 & Down & cadherin 6 \\
\hline ILMN_1752046 & SH2B3 & -0.30284 & 0.003129 & 0.044068 & -3.02278 & Down & SH2B adaptor protein 3 \\
\hline ILMN_1656300 & GFRA2 & -0.30283 & 0.000222 & 0.012233 & -3.82121 & Down & GDNF family receptor alpha 2 \\
\hline ILMN_2148459 & $\mathrm{B} 2 \mathrm{M}$ & -0.30266 & 0.003487 & 0.046567 & -2.98705 & Down & beta-2-microglobulin \\
\hline ILMN_1795639 & MGMT & -0.30229 & 0.000215 & 0.012004 & -3.83117 & Down & O-6-methylguanine-DNA methyltransferase \\
\hline ILMN_1687335 & FLNA & -0.30213 & 0.00045 & 0.017125 & -3.62022 & Down & $\begin{array}{c}\text { filamin A } \\
\text { transient receptor potential cation channel }\end{array}$ \\
\hline ILMN_2049536 & TRPV2 & -0.30191 & $5 \mathrm{E}-05$ & 0.005957 & -4.22548 & Down & subfamily V member 2 \\
\hline ILMN_1668721 & CCND3 & -0.30153 & 0.003431 & 0.046061 & -2.99245 & Down & cyclin D3 \\
\hline ILMN_1801226 & DOCK6 & -0.30138 & 0.000109 & 0.008759 & -4.01846 & Down & dedicator of cytokinesis 6 \\
\hline ILMN_3238196 & CYTH4 & -0.30118 & 0.001775 & 0.0328 & -3.20526 & Down & cytohesin 4 \\
\hline ILMN_1760667 & POLR3GL & -0.30114 & 0.000115 & 0.009 & -4.00214 & Down & RNA polymerase III subunit G like \\
\hline ILMN_2367707 & PKN1 & -0.30078 & $1.76 \mathrm{E}-05$ & 0.004057 & -4.49419 & Down & protein kinase $\mathrm{N} 1$ \\
\hline ILMN_1756439 & SCRN1 & -0.30064 & $2.03 \mathrm{E}-05$ & 0.004408 & -4.45788 & Down & secernin 1 \\
\hline ILMN_1746704 & TRIM8 & -0.30043 & $1.71 \mathrm{E}-06$ & 0.001955 & -5.06366 & Down & tripartite motif containing 8 \\
\hline ILMN_1727043 & COLGALT1 & -0.30041 & $1.61 \mathrm{E}-06$ & 0.001955 & -5.0774 & Down & collagen beta(1-O)galactosyltransferase 1 \\
\hline ILMN_1789639 & FMOD & -0.29998 & 0.000703 & 0.020621 & -3.48914 & Down & fibromodulin \\
\hline
\end{tabular}




\begin{tabular}{|c|c|c|c|c|c|c|c|}
\hline ILMN_1759513 & RND3 & -0.2987 & 0.00056 & 0.018724 & -3.5563 & Down & Rho family GTPase 3 \\
\hline ILMN_2339294 & LILRB5 & -0.29854 & 0.000286 & 0.013933 & -3.75069 & Down & leukocyte immunoglobulin like receptor B5 \\
\hline ILMN_2205896 & MEIS3P1 & -0.29849 & $3.51 \mathrm{E}-05$ & 0.005215 & -4.31774 & Down & Meishomeobox 3 pseudogene 1 \\
\hline ILMN_1677404 & RAP2A & -0.29848 & $1.01 \mathrm{E}-05$ & 0.003119 & -4.63287 & Down & RAP2A, member of RAS oncogene family \\
\hline ILMN_1716678 & NPC2 & -0.29813 & 0.000259 & 0.013173 & -3.77819 & Down & $\begin{array}{l}\text { NPC intracellular cholesterol transporter } 2 \\
\text { FYN proto-oncogene, Src family tyrosine }\end{array}$ \\
\hline ILMN_1686555 & FYN & -0.29766 & 6.74E-05 & 0.006914 & -4.14687 & Down & $\begin{array}{l}\text { kinase } \\
\text { beta-1,4-mannosyl-glycoprotein 4-beta-N- }\end{array}$ \\
\hline ILMN_1853824 & MGAT3 & -0.29749 & 0.000891 & 0.023304 & -3.4178 & Down & acetylglucosaminyltransferase \\
\hline ILMN_1661264 & SHMT2 & -0.29747 & 0.000466 & 0.017456 & -3.61015 & Down & serine hydroxymethyltransferase 2 \\
\hline ILMN_1748206 & $\mathrm{CCM} 2 \mathrm{~L}$ & -0.29721 & 0.001703 & 0.032137 & -3.21833 & Down & CCM2 like scaffold protein \\
\hline ILMN_1724480 & AXIN2 & -0.29689 & 0.000111 & 0.008868 & -4.01392 & Down & $\operatorname{axin} 2$ \\
\hline ILMN_1776157 & SEPTIN4 & -0.29638 & 0.000337 & 0.014847 & -3.70339 & Down & septin 4 \\
\hline ILMN_1775734 & SH2D3C & -0.29607 & 0.001157 & 0.02618 & -3.33856 & Down & $\mathrm{SH} 2$ domain containing $3 \mathrm{C}$ \\
\hline ILMN_1761159 & ESYT1 & -0.29576 & $9.88 \mathrm{E}-06$ & 0.003091 & -4.63908 & Down & extended synaptotagmin 1 \\
\hline ILMN_1770824 & ARHGAP4 & -0.29525 & 0.000371 & 0.015365 & -3.67562 & Down & $\begin{array}{l}\text { Rho GTPase activating protein } 4 \\
\text { ABL proto-oncogene } 1 \text { non-receptor tyrosine }\end{array}$ \\
\hline ILMN_1713732 & ABL1 & -0.29499 & $1.21 \mathrm{E}-05$ & 0.003404 & -4.58941 & Down & kinase \\
\hline ILMN_1687440 & HIPK2 & -0.2942 & 0.001881 & 0.033734 & -3.1869 & Down & homeodomain interacting protein kinase 2 \\
\hline ILMN_1694539 & MAP3K6 & -0.29418 & $7.48 \mathrm{E}-05$ & 0.007229 & -4.11899 & Down & mitogen-activated protein kinase kinasekinase 6 \\
\hline ILMN_2381697 & P4HA2 & -0.29305 & 0.000174 & 0.010872 & -3.88914 & Down & prolyl 4-hydroxylase subunit alpha 2 \\
\hline ILMN_1803348 & EHBP1 & -0.29305 & 0.000173 & 0.010825 & -3.89106 & Down & EH domain binding protein 1 \\
\hline ILMN_1776464 & PARP4 & -0.29295 & 4.71E-05 & 0.005816 & -4.24138 & Down & poly(ADP-ribose) polymerase family member 4 \\
\hline ILMN_1671404 & SVIL & -0.29228 & 0.00024 & 0.012746 & -3.79968 & Down & supervillin \\
\hline ILMN_1769118 & SEPTIN9 & -0.29218 & 0.000231 & 0.012551 & -3.81002 & Down & septin 9 \\
\hline ILMN_2315789 & PTPRD & -0.292 & 0.000226 & 0.012397 & -3.81635 & Down & $\begin{array}{l}\text { protein tyrosine phosphatase receptor type } \mathrm{D} \\
\text { signal transducer and activator of transcription }\end{array}$ \\
\hline ILMN_2401978 & STAT3 & -0.29197 & $2.58 \mathrm{E}-06$ & 0.002346 & -4.96523 & Down & 3 \\
\hline ILMN_1785424 & ABLIM1 & -0.29182 & 0.002923 & 0.042546 & -3.04516 & Down & actin binding LIM protein 1 \\
\hline ILMN_2082585 & SNAI2 & -0.29137 & 0.000937 & 0.02378 & -3.40282 & Down & snail family transcriptional repressor 2 \\
\hline ILMN_1809850 & $\mathrm{RCN} 3$ & -0.2896 & 0.000133 & 0.009736 & -3.96254 & Down & reticulocalbin 3 \\
\hline ILMN_3246065 & CCDC151 & -0.28935 & 0.000122 & 0.009241 & -3.98798 & Down & coiled-coil domain containing 151 \\
\hline ILMN_1745806 & PEMT & -0.28934 & 0.000161 & 0.010372 & -3.91073 & Down & phosphatidylethanolamine $\mathrm{N}$-methyltransferase \\
\hline ILMN_1791226 & NXN & -0.28912 & $6.77 \mathrm{E}-05$ & 0.006914 & -4.14567 & Down & nucleoredoxin \\
\hline ILMN_1758315 & SLC9A9 & -0.28902 & 0.000259 & 0.013173 & -3.77817 & Down & solute carrier family 9 member A9 \\
\hline ILMN_1661194 & CLDN14 & -0.28826 & 0.000466 & 0.017456 & -3.61005 & Down & claudin 14 \\
\hline ILMN_3225591 & RPL14 & -0.28806 & 0.000665 & 0.020117 & -3.50549 & Down & ribosomal protein L14 \\
\hline ILMN_2232712 & MYO10 & -0.28774 & 0.001061 & 0.02524 & -3.36484 & Down & myosin $\mathrm{X}$ \\
\hline ILMN_1913060 & CMKLR1 & -0.28763 & 0.00032 & 0.014545 & -3.71847 & Down & chemerin chemokine-like receptor 1 \\
\hline ILMN_1789502 & GPC4 & -0.28702 & 0.001807 & 0.033091 & -3.19966 & Down & glypican 4 \\
\hline ILMN_2047599 & TMEM50B & -0.28576 & 0.001003 & 0.024564 & -3.38214 & Down & transmembrane protein $50 \mathrm{~B}$ \\
\hline ILMN_1719543 & MAF & -0.28566 & 0.000438 & 0.016832 & -3.62816 & Down & MAF bZIP transcription factor \\
\hline ILMN_1748625 & TCEAL4 & -0.2856 & 0.000494 & 0.01788 & -3.59303 & Down & transcription elongation factor A like 4 \\
\hline ILMN_1670134 & FADS1 & -0.28515 & 0.000296 & 0.01409 & -3.74097 & Down & fatty acid desaturase 1 \\
\hline ILMN_1660871 & NEK6 & -0.28507 & 0.000893 & 0.023304 & -3.41739 & Down & $\begin{array}{c}\text { NIMA related kinase } 6 \\
\text { tyrosine } 3 \text {-monooxygenase/tryptophan 5- }\end{array}$ \\
\hline ILMN_1674385 & YWHAQ & -0.28455 & $2.86 \mathrm{E}-05$ & 0.004971 & -4.37044 & Down & monooxygenase activation protein theta \\
\hline
\end{tabular}




\begin{tabular}{|c|c|c|c|c|c|c|c|}
\hline ILMN_1681515 & CRLF1 & -0.2833 & 0.002663 & 0.04025 & -3.07546 & Down & cytokine receptor like factor 1 \\
\hline ILMN_1782086 & AOC3 & -0.28296 & 0.000461 & 0.01734 & -3.61347 & Down & $\begin{array}{l}\text { amine oxidase copper containing } 3 \\
\text { mitogen-activated protein kinase kinasekinase }\end{array}$ \\
\hline ILMN_1733538 & RGS10 & -0.28222 & 0.001065 & 0.025246 & -3.36393 & Down & regulator of $\mathrm{G}$ protein signaling 10 \\
\hline ILMN_2185884 & DHRS4 & -0.28207 & 0.001328 & 0.028154 & -3.29599 & Down & dehydrogenase/reductase 4 \\
\hline ILMN_2381899 & OPTN & -0.28193 & 0.000301 & 0.014133 & -3.73615 & Down & optineurin \\
\hline ILMN_3202024 & FTL & -0.28175 & 0.00324 & 0.044809 & -3.01128 & Down & ferritin light chain \\
\hline ILMN_1815500 & ITPR3 & -0.28174 & 0.002482 & 0.038752 & -3.09823 & Down & inositol 1,4,5-trisphosphate receptor type 3 \\
\hline ILMN_1684554 & COL16A1 & -0.28149 & 0.001102 & 0.025658 & -3.35341 & Down & collagen type XVI alpha 1 chain \\
\hline ILMN_1709590 & PGM5 & -0.28126 & 0.000681 & 0.020348 & -3.49848 & Down & phosphoglucomutase 5 \\
\hline ILMN_1913678 & IRAK3 & -0.28034 & 0.002099 & 0.035634 & -3.15202 & Down & interleukin 1 receptor associated kinase 3 \\
\hline ILMN_1815745 & SOX4 & -0.27903 & 4.4E-05 & 0.005755 & -4.25887 & Down & $\begin{array}{l}\text { SRY-box transcription factor } 4 \\
\text { NYN domain and retroviral integrase }\end{array}$ \\
\hline ILMN_3236858 & NYNRIN & -0.2784 & $4.66 \mathrm{E}-05$ & 0.005784 & -4.24391 & Down & containing \\
\hline ILMN_1800634 & NME4 & -0.27818 & 0.000791 & 0.022033 & -3.4539 & Down & $\begin{array}{l}\text { NME/NM23 nucleoside diphosphate kinase } 4 \\
\text { splA/ryanodine receptor domain and SOCS box }\end{array}$ \\
\hline ILMN_1714170 & SPSB1 & -0.27787 & 0.001682 & 0.031939 & -3.22231 & Down & containing 1 \\
\hline ILMN_1698725 & FRMD3 & -0.27757 & 0.002954 & 0.042707 & -3.04173 & Down & FERM domain containing 3 \\
\hline ILMN_1695946 & TRNP1 & -0.27716 & $1.26 \mathrm{E}-05$ & 0.003423 & -4.57872 & Down & TMF1 regulated nuclear protein 1 \\
\hline ILMN_1654065 & АТОH8 & -0.27686 & 0.001152 & 0.02613 & -3.33982 & Down & atonal bHLH transcription factor 8 \\
\hline ILMN_1739885 & SLC41A3 & -0.27657 & $2.16 \mathrm{E}-07$ & 0.000867 & -5.53926 & Down & solute carrier family 41 member 3 \\
\hline ILMN_1693826 & HAVCR2 & -0.27451 & 0.003493 & 0.046607 & -2.98647 & Down & hepatitis A virus cellular receptor 2 \\
\hline ILMN_1659206 & RARA & -0.27351 & 0.00249 & 0.038808 & -3.09718 & Down & retinoic acid receptor alpha \\
\hline
\end{tabular}

Table 3 The enriched GO terms of the up and down regulated differentially expressed genes

\begin{tabular}{|c|c|c|c|c|c|c|c|c|}
\hline GO ID & CATEGORY & GO Name & P Value & $\begin{array}{l}\text { FDR } \\
\text { B\&H }\end{array}$ & $\begin{array}{l}\text { FDR } \\
\text { B\&Y }\end{array}$ & Bonferroni & $\begin{array}{c}\text { Gene } \\
\text { Count }\end{array}$ & Gene \\
\hline \multicolumn{9}{|c|}{ Up regulated genes } \\
\hline \multirow[t]{21}{*}{ GO:0000003 } & $\mathrm{BP}$ & reproduction & $1.54 \mathrm{E}-05$ & $1.92 \mathrm{E}-02$ & $1.75 \mathrm{E}-01$ & $7.69 \mathrm{E}-02$ & 59 & CEBPB,GRHL2,ACSL \\
\hline & & & & & & & & $4, \mathrm{~S} 100 \mathrm{~A} 11, \mathrm{KMT} 2 \mathrm{C}, \mathrm{U}$ \\
\hline & & & & & & & & BE2A,TESK2,AGFG1 \\
\hline & & & & & & & & ,AHR,HES1,MAFF,H \\
\hline & & & & & & & & SD11B2,PAQR7,RHO \\
\hline & & & & & & & & BTB3,NECTIN3,CRH, \\
\hline & & & & & & & & SLC4A2,STS,CSNK2 \\
\hline & & & & & & & & A2,SLC22A5,GABRB \\
\hline & & & & & & & & 1,PLAC1,SPIRE2,PSG \\
\hline & & & & & & & & 1,PSG2,ING2,PSG3,I \\
\hline & & & & & & & & NHA,PSG4,PSG5,PSG \\
\hline & & & & & & & & 6,PSG7,PSG9,CYP11 \\
\hline & & & & & & & & A1,PSG11,CYP19A1, \\
\hline & & & & & & & & YTHDC1,SEPTIN6,S \\
\hline & & & & & & & & TAT5B,CREBRF,NFE \\
\hline & & & & & & & & 2,SPIN1,STRA6,MBD \\
\hline & & & & & & & & 2,DDR1,TBX3,CAST, \\
\hline & & & & & & & & CGB7,TEAD3,LHB,G \\
\hline & & & & & & & & MCL1,OVGP1,TIAL1, \\
\hline & & & & & & & & EGFR,INSL6,LNPEP, \\
\hline & & & & & & & & $\begin{array}{c}\text { TLR3,TMF1,PLEKHA } \\
1\end{array}$ \\
\hline \multirow[t]{2}{*}{ GO:0009057 } & $\mathrm{BP}$ & macromolec & $5.89 \mathrm{E}-04$ & $1.28 \mathrm{E}-01$ & $1.00 \mathrm{E}+00$ & $1.00 \mathrm{E}+00$ & 48 & CARHSP1,RPS13,WA \\
\hline & & ule catabolic & & & & & & $\mathrm{C}, \mathrm{UBE} 2 \mathrm{~A}, \mathrm{UBE} 2 \mathrm{D} 3, \mathrm{C}$ \\
\hline
\end{tabular}


bioRxiv preprint doi: https://doi.org/10.1101/2021.03.09.434569; this version posted March 10, 2021. The copyright holder for this preprint (which was not certified by peer review) is the author/funder. All rights reserved. No reuse allowed without permission.

process

GO:0042175

GO:0005794

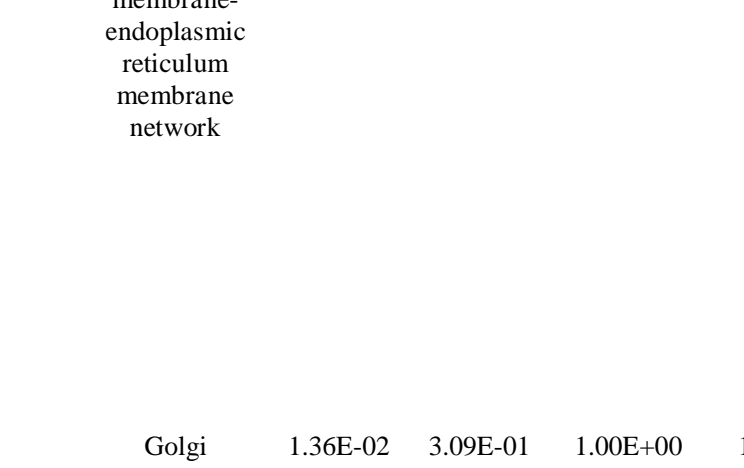

CC

apparatus

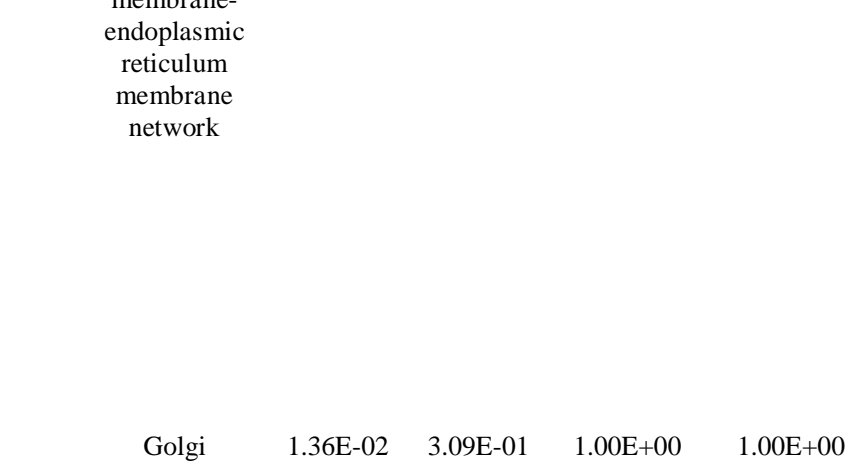

$\begin{array}{cccc}\begin{array}{c}\text { nuclear outer } \\ \text { membrane- } \\ \text { endoplasmic } \\ \text { reticulum } \\ \text { membrane } \\ \text { network }\end{array} & 1.06 \mathrm{E}-03 & 1.69 \mathrm{E}-01 & 1.00 \mathrm{E}+00 \\ & & & \\ \text { Golgi } & 1.36 \mathrm{E}-02 & 3.09 \mathrm{E}-01 & 1.00 \mathrm{E}+00\end{array}$

$1.00 \mathrm{E}+00$

$6.75 \mathrm{E}-01$

GO:0042802
MF
LN3,UCHL3,LYPLA1 ,HSPB1,HSP90AA1,A MFR,DCP2,IDS,AZIN 1,IGF2BP3,IGF2BP2, GET4,CSNK2A2,MT M1,NCAN,TNKS1BP 1,USP33,TRIM25,PS MA3,PSMC4,DDB1,C REBRF,PTPN3,STX5 FBXO9,SMG9,PJA1, USP27X,RBX1,RBBP 6,CAST,RDX,PELI1, NCCRP1,STT3B,RYB P,OVGP1,EGFR,TIM P2,LNPEP,PKP3,FUR IN,TMF1

SPTLC3,CDS1,BET1, ACSL4,SPCS3,PIGH,

EVA1A,CLN3,HSD3B 1,ULK1,HSD11B2,FK BP2,AMFR,FOLR1,S PTLC1,RAB3GAP1,S TS,NSG1,GDPD1,GP AA1,CYP19A1,STX5, BCAP29,NUP153,TO R1AIP2,CAMK2G,NU CB2,CASP4,TMED4, STT3B,RASGRP1,MF SD2A,SPPL2A,EGFR, LPCAT3,FURIN,TLR 3,PAFAH2

SGSM1,CNST,BET1, SPG21,ST3GAL6,CL N3,AMFR,ANK3,FOL R1,GDF15,YIPF4,RH OBTB3,ST3GAL4,RA B3GAP1,STS,NCAN, NSG1,PDE4DIP,RAB 11FIP5,FHDC1,TBC1 D23,STX11,CSGALN ACT1,ECE2,USP33,A CER2,ATP6V0C,ING 2,STK26,C1GALT1,C OG3,BMP1,STX5,AP 1G2,TAF7,GOLGA4, YIPF6,NUCB2,TMED 4,LHB,RASGRP1,EG FR,FURIN,TLR3,TMF 1,ELF3

CEBPB,IER5,TWIST1 ,S100A11,S100P,H2B C8,H2BC6,H2BC4,TL E5,CLK3,AHR,UCK2, TRPV6,HES1,HOOK2 ,ULK1,HSPB1,CAP2, HSP90AA1,AMFR, G DF15,ANXA4,SRR,C LDN7,NECTIN3, CGG BP1,TBK1,GRAMD2 B,ATF3,RIPOR2,STK 26,NAB2,DAPK1,BM P1,JUP,DHPS,SMG9, KYNU,HSPB8,NUP15 3,YIPF6,CAMK2G,D YRK1A,GRB7,RDX, UBA3,TDG,CLDN8,T FRC,GMCL1,RASGR P1,SPPL2A,EGFR,CB X5,ENTPD1,TLR3,PA K1,PAK2,SPATA13 
bioRxiv preprint doi: https://doi.org/10.1101/2021.03.09.434569; this version posted March 10, 2021. The copyright holder for this preprint (which was not certified by peer review) is the author/funder. All rights reserved. No reuse allowed without permission.

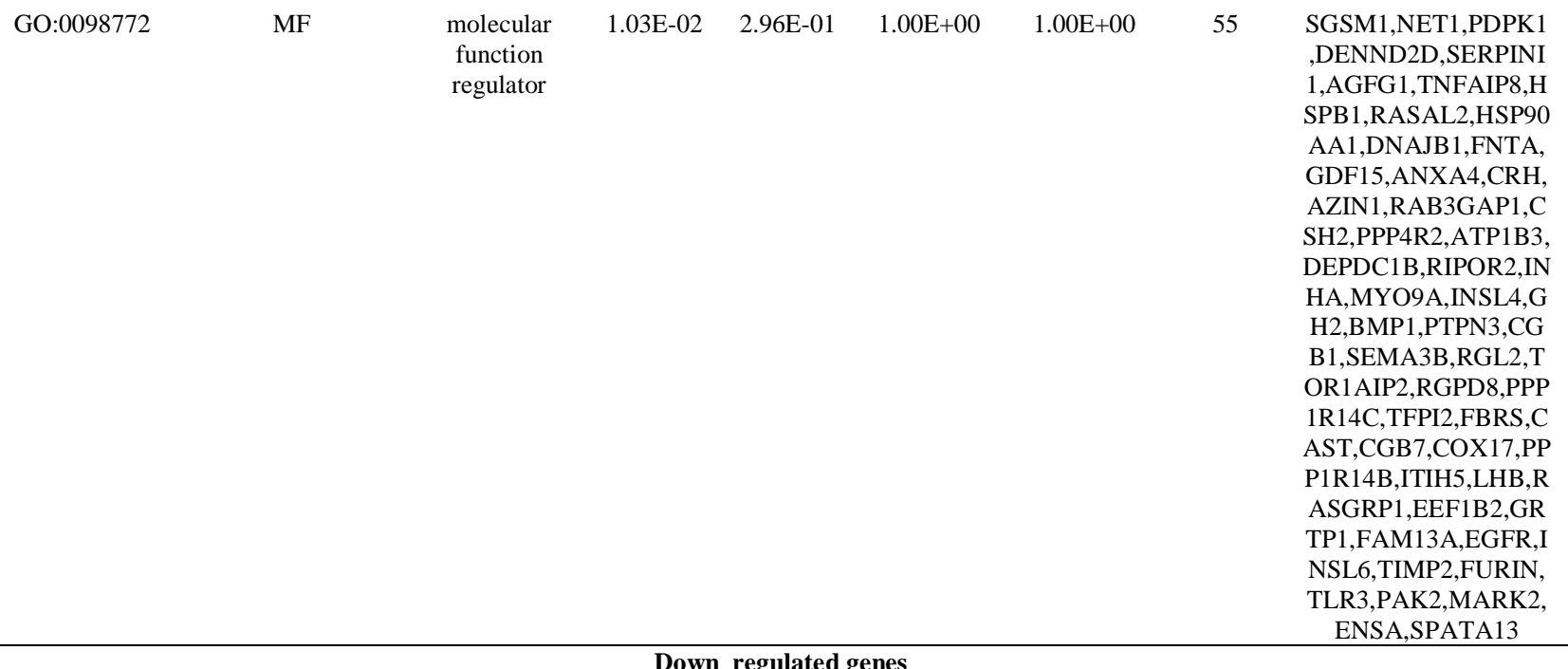

$\begin{array}{llllll}\text { GO:0007155 } & \text { BP } & \text { cell adhesion } & 4.46 \mathrm{E}-28 & 8.58 \mathrm{E}-25 & 7.92\end{array}$


bioRxiv preprint doi: https://doi.org/10.1101/2021.03.09.434569; this version posted March 10, 2021. The copyright holder for this preprint (which was not certified by peer review) is the author/funder. All rights reserved. No reuse allowed without permission.

GO:0099080

GO:0030054
$\mathrm{CC}$

$$
\begin{aligned}
& \text { supramolecul } \\
& \text { ar complex }
\end{aligned}
$$
$3.08 \mathrm{E}-13$ 1 $.81 \mathrm{E}-11$

cell junction

CC
$3.95 \mathrm{E}-13$

\begin{abstract}
$24 \mathrm{E}-10$
\end{abstract}
1.63E-10

77

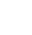

NN2,VCAM1,VCL,F
OXF1,COL1A1,COL1
A2,PMP22,VEGFC,C
OL3A1,COL5A1,FLN
A,DDIT4,VTN,ADA
MTS1,PODXL,FOLR2
,CXCL14,ADGRA2,P
DPN,RND3,ARHGAP
4,IGFBP3,PRCP,PPM
1F,VCAN,CSPG4,SLI
T3,PARVA,SNAI,A
OC3,PRKCA,PKN1,C
CN2,EGFLAM,CAVI
N1,FSCN1,FYN,NEX
N,HYAL2,PROS1,MY
ADM,SPARC,MYO10
,AXL,ADAM15,TNFR
SF14,GAS6,TUBB2B,
NDN,ITGA1,DCN,ST
AT3,STC1,ADAMTS9
,BST2,ACKR3,TSPO,
RIPOR1,BRAT1,RAP
2A,RARRES2,CD248,
GPER1,DDR2,LAMA
2,LAMA4,LAMB2,LA
MC1,CAV1,TEK,PIP5
K1C,LPAR1,LDB2,C
OL18A1,ARAP3,THY
1,LMNA,FAM107A,T
IMP1,ATOH8,CD44,S
PRED1,CD81,ARHGE
F2,SMAD3,EPHA3 F2,SMAD3,EPHA3 TPM2,CYBRD1,MAP 1B,ACTA2,ACTG2, T UBB2A,PGM5,TBCB, MFAP4,PARP4,FAT1, MYL9,PEMT,ANTXR 1,CCDC151,CNN2,V CAM1,VCL,COL1A1, COL1A2,COL3A1,CO L4A1,COL4A2,COL4 A5,COL5A1,COL5A2, COL6A1,FLNA,COL6 A3,BIN1,SHROOM3, FBLN5,SEPTIN4,POD XL,NCKAP5L,ADGR A2,SMTN,PDPN,ARH GAP4,FEZ1,PARVA, AOC3,FSCN1,FYN,N EXN,HYAL2,NES,M YH11,NEK6,MYO10, SEPTIN9,SPTAN1,TU BB2B,AIF1L,DCN,PT H1R,ITPR3,PDLIM3, SVIL,FERMT2,DPYS L2,CALD1,GPER1,SY NM,TEK, RHOQ,ABL IM1,OXTR,LMNA,FA M107A,FARP1,CD36, LPP,CD44,PALM,AR HGEF2,TNNT3 CLDN14,MAP1B,PD GFRB,PGM5,FZD4,F AT1,CAMK2N1,CD99 ,JAG1,FGFR3,CNN2, ARHGEF6,VCL,PMP 22,FLNA,SHROOM3, PODXL,YWHAH,CY FIP2,LIMS2,PDPN,R ND3,CSPG4,PARVA, 
bioRxiv preprint doi: https://doi.org/10.1101/2021.03.09.434569; this version posted March 10, 2021. The copyright holder for this preprint (which was not certified by peer review) is the author/funder. All rights reserved. No reuse allowed without permission.

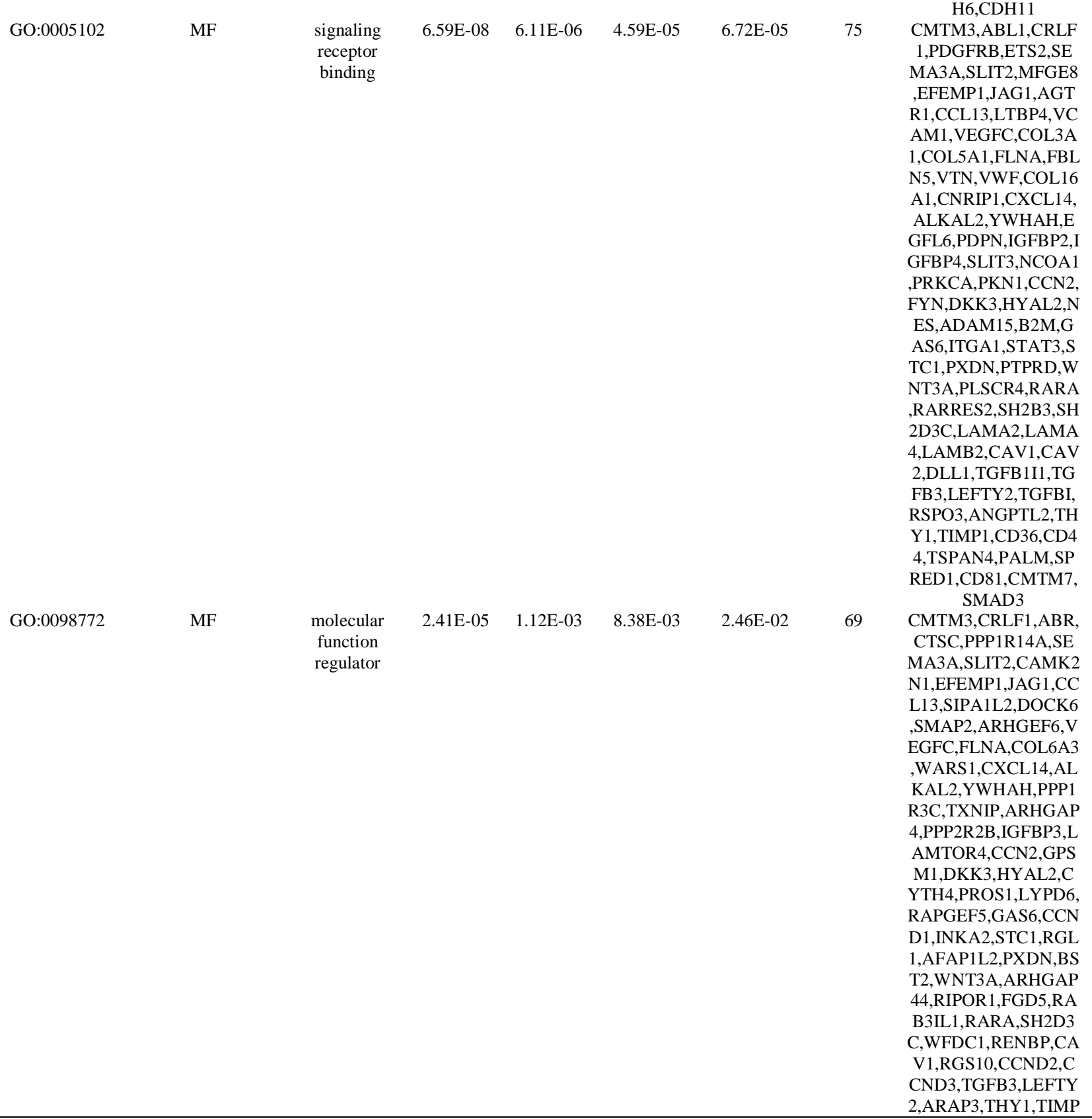


bioRxiv preprint doi: https://doi.org/10.1101/2021.03.09.434569; this version posted March 10, 2021. The copyright holder for this preprint (which was not certified by peer review) is the author/funder. All rights reserved. No reuse allowed without permission.

$1, \mathrm{ABCE} 1, \mathrm{FARP} 1, \mathrm{SPR}$ ED1,ARHGEF2,CMT M7,AGRN,PCOLCE

Biological Process(BP), Cellular Component(CC) and Molecular Functions (MF)

Table 4 The enriched pathway terms of the up and down regulated differentially expressed genes

\begin{tabular}{|c|c|c|c|c|c|c|c|}
\hline Pathway ID & $\begin{array}{c}\text { Pathway } \\
\text { Name }\end{array}$ & P-value & $\begin{array}{l}\text { FDR } \\
\text { B\&H }\end{array}$ & $\begin{array}{l}\text { FDR } \\
\text { B\&Y }\end{array}$ & Bonferroni & $\begin{array}{l}\text { Gene } \\
\text { Count }\end{array}$ & Gene \\
\hline \multicolumn{8}{|c|}{ Up regulated genes } \\
\hline 1269373 & $\begin{array}{c}\text { Cell surface } \\
\text { interactions at } \\
\text { the vascular wall }\end{array}$ & $2.86 \mathrm{E}-05$ & $4.73 \mathrm{E}-03$ & $3.47 \mathrm{E}-02$ & $2.46 \mathrm{E}-02$ & 13 & $\begin{array}{l}\text { PSG8,SLC3A2,ATP1B } \\
\text { 3,PSG1,PSG2,PSG3,P } \\
\text { SG4,PSG5,PSG6,PSG } \\
\text { 7.PSG9,PSG11.GRB7 }\end{array}$ \\
\hline 1269734 & $\begin{array}{l}\text { Epigenetic } \\
\text { regulation of } \\
\text { gene expression }\end{array}$ & 8.47E-04 & $2.18 \mathrm{E}-02$ & $1.60 \mathrm{E}-01$ & $7.28 \mathrm{E}-01$ & 11 & $\begin{array}{c}\mathrm{H} 2 \mathrm{AC} 6, \mathrm{H} 2 \mathrm{BC} 8, \mathrm{H} 2 \mathrm{BC} \\
6, \mathrm{H} 2 \mathrm{BC} 4, \mathrm{H} 2 \mathrm{BC} 21, \mathrm{H} 4 \\
\mathrm{C} 8, \mathrm{H} 2 \mathrm{BC} 12, \mathrm{MBD} 2, \mathrm{~T} \\
\mathrm{AF} 1 \mathrm{~B}, \mathrm{TDG}, \mathrm{H} 2 \mathrm{BC} 5\end{array}$ \\
\hline 1270001 & $\begin{array}{l}\text { Metabolism of } \\
\text { lipids and } \\
\text { lipoproteins }\end{array}$ & $1.33 \mathrm{E}-03$ & $2.87 \mathrm{E}-02$ & $2.10 \mathrm{E}-01$ & $1.00 \mathrm{E}+00$ & 33 & $\begin{array}{c}\text { OLAH,SPTLC3,CDS1 } \\
\text {,ACADVL,ACOX3,A } \\
\text { CSL4,AHR,PIP5K1B, } \\
\text { HSD3B1,TNFAIP8,HS } \\
\text { D11B2,SH3KBP1,SPT } \\
\text { LC1,TNFAIP8L1,PLE } \\
\text { KHA6,STS,CSNK2A2 } \\
\text {,MTM1,ACER2,GDP } \\
\text { D1,CYP11A1,CYP19 } \\
\text { A1,BMP1,TEAD3,LH } \\
\text { B,MFSD2A,MTMR4, } \\
\text { ABHD5,LPCAT3,FUR } \\
\text { IN,AKR1B15,PLEKH } \\
\text { A1,RORA }\end{array}$ \\
\hline 1268701 & $\begin{array}{l}\text { Post-translational } \\
\text { protein } \\
\text { modification }\end{array}$ & $3.57 \mathrm{E}-03$ & $6.02 \mathrm{E}-02$ & $4.41 \mathrm{E}-01$ & $1.00 \mathrm{E}+00$ & 38 & $\begin{array}{c}\text { BET1,WAC,H2AC6,H } \\
\text { 2BC8,UBE2A,H2BC6, } \\
\text { H2BC4,UBE2D3,H2B } \\
\text { C21,ST3GAL6,PIGH, } \\
\text { UCHL3,ADAMTSL4, } \\
\text { H2BC12,AMFR,ANK } \\
\text { 3,FOLR1,ST3GAL4,S } \\
\text { TS,BABAM1,USP3,, } \\
\text { TRIM25,GPAA1,INO } \\
\text { 80C,PSMA3,PSMC4, } \\
\text { C1GALT1,COG3,H2A } \\
\text { W,STX5,DHPS,NUP1 } \\
\text { 53,RAB25,GNE,TDG, } \\
\text { LHB,FURIN,H2BC5 }\end{array}$ \\
\hline 1268677 & $\begin{array}{l}\text { Metabolism of } \\
\text { proteins }\end{array}$ & $1.06 \mathrm{E}-02$ & $1.30 \mathrm{E}-01$ & $9.49 \mathrm{E}-01$ & $1.00 \mathrm{E}+00$ & 52 & $\begin{array}{c}\text { ACADVL,BET1,RPS1 } \\
\text { 3,WAC,H2AC6,SPCS } \\
\text { 3,H2BC8,UBE2A,H2B } \\
\text { C6,H2BC4,UBE2D3,H } \\
\text { 2BC21,ST3GAL6,PIG } \\
\text { H,H4C8,UCHL3,ADA } \\
\text { MTSL4,H2BC12,AMF } \\
\text { R,ANK3,FOLR1,DCP } \\
\text { 2,ST3GAL4,STS,BAB } \\
\text { AM1,CSNK2A2,ATF3 } \\
\text {,ATF4,CGB5,USP33, } \\
\text { HCHD10,TRIM25,GP } \\
\text { AA1,INO80C,INHA,P } \\
\text { SMA3,PSMC4,C1GA } \\
\text { LT1,COG3,H2AW,ST } \\
\text { X5,GNG12,DHPS,NU } \\
\text { P153,RAB25,GNE,CO } \\
\text { X17,TDG,LHB,EEF1 } \\
\text { B2,FURIN,H2BC5 }\end{array}$ \\
\hline 1270302 & Developmental & $1.79 \mathrm{E}-02$ & $1.92 \mathrm{E}-01$ & $1.00 \mathrm{E}+00$ & $1.00 \mathrm{E}+00$ & 36 & CEBPB,RPS6KA5,PF \\
\hline
\end{tabular}


bioRxiv preprint doi: https://doi.org/10.1101/2021.03.09.434569; this version posted March 10, 2021. The copyright holder for this preprint (which was not certified by peer review) is the author/funder. All rights reserved. No reuse allowed without permission.

Biology

N2,KMT2C,H2AC6,H

2BC8,H2BC6,H2BC4,

H2BC21,H4C8,HES1,

H2BC12,RASAL2,CA

P2,HSP90AA1,ANK3,

KRT23,CSNK2A2,NC

AN,PSMA3,PSMC4,J

UP,KAZN,KRTAP26-

1,RBX1,CAMK2G,GR

B7,RDX,RASGRP1,T

CHH,EGFR,PKP3,FU

RIN,PAK1,PAK2,H2B

C5

\begin{tabular}{|c|c|c|c|c|c|c|c|}
\hline \multicolumn{8}{|c|}{ Down regulated genes } \\
\hline 1270244 & $\begin{array}{l}\text { Extracellular } \\
\text { matrix } \\
\text { organization }\end{array}$ & $1.93 \mathrm{E}-23$ & $1.40 \mathrm{E}-20$ & $1.00 \mathrm{E}-19$ & $1.40 \mathrm{E}-20$ & 46 & $\begin{array}{c}\text { LAMC3,MFAP4,FBL } \\
\text { N2,EFEMP1,PLOD1,L } \\
\text { TBP4,VCAM1,COL1 } \\
\text { A1,COL1A2,COL3A1, } \\
\text { COL4A1,COL4A2,CO } \\
\text { L4A5,COL5A1,COL5 } \\
\text { A2,COL6A1,COL6A2, } \\
\text { COL6A3,COL8A2,FB } \\
\text { LN5,VTN,FMOD,CO } \\
\text { L16A1,ADAMTS1,EF } \\
\text { EMP2,VCAN,PRKCA } \\
\text {,SPARC,ADAM15,IT } \\
\text { GA1,DCN,ADAMTS } \\
\text {,P4HA2,DDR2,LAMA } \\
\text { 2,LAMA4,LAMB2,LA } \\
\text { MC1,COLGALT1,TG } \\
\text { FB3,COL18A1,TIMP1 } \\
\text {,CD44,LTBP2,AGRN, } \\
\text { PCOLCE }\end{array}$ \\
\hline 1270303 & Axon guidance & $3.15 \mathrm{E}-05$ & $1.35 \mathrm{E}-03$ & $9.67 \mathrm{E}-03$ & $2.29 \mathrm{E}-02$ & 31 & $\begin{array}{c}\text { ABL1,PDGFRB,RPS6 } \\
\text { KA2,SEMA3A,SLIT2, } \\
\text { MYL9,FGFR3,VCL,C } \\
\text { OL4A1,COL4A2,COL } \\
\text { 4A5,COL6A1,COL6A } \\
\text { 2,COL6A3,VWF,SLIT } \\
\text { 3,PRKCA,FYN,MYH1 } \\
\text { 1,MYO10,SPTAN1,IT } \\
\text { GA1,GFRA2,DPYSL2 } \\
\text {,LAMC1,TEK,PIP5K1 } \\
\text { C,ABLIM1,SPRED1, } \\
\text { AGRN,EPHA3 }\end{array}$ \\
\hline 1269478 & $\begin{array}{l}\text { Signaling by } \\
\text { PDGF }\end{array}$ & $2.76 \mathrm{E}-04$ & $7.15 \mathrm{E}-03$ & $5.13 \mathrm{E}-02$ & $2.00 \mathrm{E}-01$ & 22 & $\begin{array}{c}\text { PDGFRB,ADCY3,FG } \\
\text { FR3,VCL,COL4A1,C } \\
\text { OL4A2,FOXO1,COL4 } \\
\text { A5,COL6A1,COL6A2, } \\
\text { COL6A3,ADCY4,VW } \\
\text { F,PRKCA,FYN,SPTA } \\
\text { N1,GFRA2,STAT3,IT } \\
\text { PR3,TEK,PIP5K1C,SP } \\
\text { RED1 }\end{array}$ \\
\hline 1269340 & Hemostasis & $1.83 \mathrm{E}-03$ & $3.51 \mathrm{E}-02$ & $2.51 \mathrm{E}-01$ & $1.00 \mathrm{E}+00$ & 29 & $\begin{array}{c}\text { ABL1,PDE9A,F3,EH } \\
\text { D2,CD99,DOCK6,VC } \\
\text { L,VEGFC,FLNA,VW } \\
\text { F,PDPN,PRCP,PRKC } \\
\text { A,FYN,PROS1,SPAR } \\
\text { C,GAS6,ITGA1,ITPR } \\
\text { 3,CFD,RARRES2,SH2 } \\
\text { B3,CAV1,TEK,TGFB } \\
\text { 3,LEFTY2,TIMP1,CD } \\
\text { 36,CD44 }\end{array}$ \\
\hline 1270302 & $\begin{array}{c}\text { Developmental } \\
\text { Biology }\end{array}$ & $6.14 \mathrm{E}-03$ & $8.76 \mathrm{E}-02$ & $6.28 \mathrm{E}-01$ & $1.00 \mathrm{E}+00$ & 41 & $\begin{array}{l}\text { ABL1,PDGFRB,RPS6 } \\
\text { KA2,SEMA3A,SLIT2, } \\
\text { MYL9,FGFR3,VCL,C } \\
\text { OL4A1,COL4A2,FOX } \\
\text { O1,COL4A5,COL6A1, } \\
\text { COL6A2,COL6A3,V }\end{array}$ \\
\hline
\end{tabular}


bioRxiv preprint doi: https://doi.org/10.1101/2021.03.09.434569; this version posted March 10, 2021. The copyright holder for this preprint (which was not certified by peer review) is the author/funder. All rights reserved. No reuse allowed without permission.

WF,SLIT3,NCOA1,PR

KCA,FYN,MYH11,M YO10,SPTAN1,ITGA 1,GFRA2,STAT3,TCF 4,DPYSL2,RARA,LA MC1,EBF1,TEK,PIP5 K1C,CCND3,LEFTY2 ABLIM1,CD36,SPRE D1,AGRN,SMAD3,EP HA3

$1269310 \quad$ Cytokine

$6.57 \mathrm{E}-03$

9.18E-02

$6.58 \mathrm{E}-01$

$1.00 \mathrm{E}+00$

31

Immune system

CRLF1,UBE2L6,PDG FRB,IFITM3,FGFR3,

VCAM1,VCL,COL1A

2,FOXO1,VWF,IFITM

2,IFNGR2,FSCN1,FY

N,SPTAN1,B2M,TNF

RSF14,CCND1,NDN,

GFRA2,STAT3,BST2,

TRIM8,TEK,HAVCR2

,TIMP1,CD36,CD44,S

PRED1,IRAK3,TNFR SF1B

Table 5 Topology table for up and down regulated genes.

\begin{tabular}{|c|c|c|c|c|c|}
\hline Regulation & Node & Degree & Betweenness & Stress & Closeness \\
\hline Up & HSP90AA1 & 655 & 0.22721 & 81351654 & 0.412863 \\
\hline Up & EGFR & 324 & 0.081831 & 21358048 & 0.396682 \\
\hline Up & RPS13 & 176 & 0.040553 & 21024400 & 0.332742 \\
\hline Up & RBX1 & 132 & 0.02978 & 9542636 & 0.3408 \\
\hline Up & PAK1 & 115 & 0.016755 & 4561194 & 0.37158 \\
\hline Up & CSNK2A2 & 112 & 0.026157 & 6172590 & 0.354758 \\
\hline Up & PAK2 & 107 & 0.012051 & 4334042 & 0.349858 \\
\hline Up & DDB1 & 105 & 0.024917 & 6240978 & 0.340602 \\
\hline Up & PSMC4 & 101 & 0.019368 & 3810802 & 0.348739 \\
\hline Up & DVL3 & 99 & 0.017256 & 5360158 & 0.344762 \\
\hline Up & UBE2D3 & 96 & 0.018158 & 6872298 & 0.333975 \\
\hline Up & SMARCB1 & 90 & 0.021042 & 7085456 & 0.333215 \\
\hline Up & STAT5B & 89 & 0.005633 & 1782886 & 0.349937 \\
\hline Up & STX5 & 86 & 0.021729 & 5783250 & 0.327692 \\
\hline Up & UBE2A & 86 & 0.01665 & 6800442 & 0.330652 \\
\hline Up & NUP153 & 81 & 0.019493 & 3839268 & 0.33388 \\
\hline Up & JUP & 79 & 0.012614 & 3875882 & 0.320148 \\
\hline Up & PSMA3 & 78 & 0.009276 & 2735940 & 0.330535 \\
\hline Up & SH3KBP1 & 76 & 0.011315 & 2648130 & 0.345321 \\
\hline Up & HSPB 1 & 69 & 0.012593 & 3676246 & 0.34167 \\
\hline Up & BET1 & 67 & 0.013941 & 4543480 & 0.325711 \\
\hline Up & AMFR & 66 & 0.018899 & 2411936 & 0.345907 \\
\hline Up & RRAS2 & 64 & 0.00438 & 2166928 & 0.301914 \\
\hline Up & MARK2 & 63 & 0.012107 & 3287228 & 0.338315 \\
\hline Up & CBX5 & 62 & 0.015481 & 3171408 & 0.327807 \\
\hline Up & СЕВРВ & 62 & 0.007601 & 2245984 & 0.350172 \\
\hline Up & PDPK1 & 62 & 0.005919 & 1612918 & 0.342169 \\
\hline Up & HNRNPH1 & 59 & 0.013608 & 2423406 & 0.335625 \\
\hline Up & DNAJB1 & 58 & 0.00611 & 1362926 & 0.344205 \\
\hline Up & ATF3 & 57 & 0.005226 & 1555506 & 0.352755 \\
\hline Up & SPATA13 & 56 & 0.00717 & 2217896 & 0.295759 \\
\hline Up & FURIN & 55 & 0.017306 & 2333572 & 0.332317 \\
\hline Up & RHOBTB1 & 54 & 0.005265 & 891404 & 0.309798 \\
\hline Up & SNAP23 & 52 & 0.010301 & 2133980 & 0.326551 \\
\hline
\end{tabular}


bioRxiv preprint doi: https://doi.org/10.1101/2021.03.09.434569; this version posted March 10, 2021. The copyright holder for this preprint (which was not certified by peer review) is the author/funder. All rights reserved. No reuse allowed without permission.

\begin{tabular}{|c|c|c|c|c|c|}
\hline Up & STX11 & 49 & 0.006356 & 1012388 & 0.276999 \\
\hline Up & TBK1 & 48 & 0.00946 & 1612462 & 0.346521 \\
\hline Up & RAB25 & 48 & 0.00796 & 4209932 & 0.282579 \\
\hline Up & ING2 & 42 & 0.006848 & 2338492 & 0.325236 \\
\hline Up & ULK1 & 42 & 0.007643 & 7120856 & 0.274292 \\
\hline Up & UCHL3 & 42 & 0.007629 & 1994146 & 0.325779 \\
\hline Up & PFN2 & 41 & 0.004889 & 1200798 & 0.329235 \\
\hline Up & CAP2 & 40 & 0.002011 & 661156 & 0.288156 \\
\hline Up & UBA3 & 40 & 0.005749 & 1625200 & 0.326187 \\
\hline Up & DYRK1A & 40 & 0.004394 & 1121650 & 0.309634 \\
\hline Up & RBM22 & 39 & 0.01146 & 1346380 & 0.322616 \\
\hline Up & TXK & 38 & 0.001513 & 482866 & 0.300558 \\
\hline Up & TAF7 & 38 & 0.010147 & 1476134 & 0.322972 \\
\hline Up & CAMK2G & 38 & 0.007152 & 1050770 & 0.341969 \\
\hline Up & ATF4 & 37 & 0.006742 & 1255258 & 0.328036 \\
\hline Up & TLR3 & 36 & 0.004686 & 1054636 & 0.305217 \\
\hline Up & MYO9A & 36 & $8.05 \mathrm{E}-04$ & 406980 & 0.28752 \\
\hline Up & BABAM1 & 36 & 0.008431 & 1423346 & 0.324044 \\
\hline Up & STK26 & 36 & 0.008804 & 1319200 & 0.323842 \\
\hline Up & ACTR3C & 35 & 0.002617 & 659206 & 0.282732 \\
\hline Up & CREB5 & 35 & 0.001154 & 566084 & 0.298035 \\
\hline Up & NET1 & 33 & 0.003076 & 787876 & 0.327189 \\
\hline Up & EEF1B2 & 32 & 0.00465 & 1484558 & 0.32501 \\
\hline Up & AHR & 32 & 0.003156 & 847220 & 0.347858 \\
\hline Up & PIP5K1B & 31 & 0.00183 & 957308 & 0.326391 \\
\hline Up & CLN3 & 31 & 0.007159 & 992822 & 0.323485 \\
\hline Up & HES1 & 30 & 0.0035 & 796872 & 0.300115 \\
\hline Up & RBBP6 & 29 & 0.008094 & 1087968 & 0.324089 \\
\hline Up & AP1G2 & 29 & 0.008892 & 933344 & 0.321377 \\
\hline Up & RDX & 29 & 0.003378 & 953914 & 0.325146 \\
\hline Up & RGPD8 & 28 & 0.002967 & 626564 & 0.32295 \\
\hline Up & HSD3B1 & 28 & 0.009418 & 6545696 & 0.230497 \\
\hline Up & COG3 & 27 & 0.00261 & 458374 & 0.24988 \\
\hline Up & ATP6V0C & 27 & 0.008472 & 953284 & 0.320959 \\
\hline Up & TFRC & 27 & 0.004398 & 847110 & 0.329004 \\
\hline Up & TIAL1 & 27 & 0.005954 & 1083682 & 0.323485 \\
\hline Up & DCP2 & 27 & 0.007451 & 4215608 & 0.243872 \\
\hline Up & CAPZA1 & 26 & 0.002869 & 626878 & 0.325191 \\
\hline Up & FKBP2 & 25 & 0.003414 & 683462 & 0.282255 \\
\hline Up & TWIST1 & 24 & 0.001372 & 488874 & 0.298643 \\
\hline Up & TIMP2 & 24 & 0.001662 & 741652 & 0.250924 \\
\hline Up & SPTLC1 & 24 & 0.008272 & 878220 & 0.320827 \\
\hline Up & DAPK1 & 24 & 0.003354 & 582304 & 0.3437 \\
\hline Up & STT3B & 23 & 0.005888 & 688678 & 0.320805 \\
\hline Up & RBMS1 & 23 & 0.005223 & 803708 & 0.322772 \\
\hline Up & ANK3 & 21 & 0.004965 & 565126 & 0.321819 \\
\hline Up & TDG & 21 & 0.00124 & 515588 & 0.326346 \\
\hline Up & CHMP5 & 20 & 0.00503 & 681262 & 0.320915 \\
\hline Up & MBD2 & 20 & 0.003168 & 3223460 & 0.265195 \\
\hline Up & TRIM25 & 20 & 0.002013 & 463938 & 0.326073 \\
\hline Up & TEAD3 & 20 & 0.001225 & 501618 & 0.323954 \\
\hline Up & SLC3A2 & 20 & 0.005187 & 569152 & 0.332435 \\
\hline Up & BMP1 & 19 & 0.00311 & 565522 & 0.259095 \\
\hline Up & RHOBTB3 & 19 & 0.002152 & 346198 & 0.322439 \\
\hline Up & CHD2 & 19 & 0.00121 & 998828 & 0.256894 \\
\hline Up & RYBP & 19 & 0.002415 & 541940 & 0.322572 \\
\hline Up & GLRX & 18 & 0.00459 & 583470 & 0.320959 \\
\hline Up & KMT2C & 18 & 0.003676 & 553422 & 0.285019 \\
\hline Up & YTHDC1 & 18 & 0.003349 & 530960 & 0.33407 \\
\hline Up & GRB7 & 18 & $5.17 \mathrm{E}-04$ & 151894 & 0.294958 \\
\hline Up & IWS1 & 17 & 0.004258 & 1715034 & 0.236798 \\
\hline Up & TRAF3IP2 & 17 & 0.001901 & 398464 & 0.324246 \\
\hline Up & CSF3R & 17 & 0.001832 & 324530 & 0.329027 \\
\hline Up & AFF1 & 17 & 0.003482 & 1512904 & 0.247805 \\
\hline Up & INO80C & 17 & 0.003498 & 441732 & 0.321245 \\
\hline Up & CASP4 & 17 & 0.002253 & 931980 & 0.263822 \\
\hline Up & YIPF6 & 17 & 0.003441 & 5013996 & 0.201367 \\
\hline Up & PCGF1 & 16 & 0.003259 & 409788 & 0.320827 \\
\hline Up & CXCR2 & 16 & 0.003899 & 2017434 & 0.253558 \\
\hline Up & ELF3 & 16 & $6.72 \mathrm{E}-04$ & 203260 & 0.333452 \\
\hline
\end{tabular}


bioRxiv preprint doi: https://doi.org/10.1101/2021.03.09.434569; this version posted March 10, 2021. The copyright holder for this preprint (which was not certified by peer review) is the author/funder. All rights reserved. No reuse allowed without permission.

\begin{tabular}{|c|c|c|c|c|c|}
\hline Up & USP33 & 16 & 0.002932 & 430028 & 0.322927 \\
\hline Up & AGFG1 & 15 & 0.003227 & 435804 & 0.321443 \\
\hline Up & LNPEP & 14 & $7.10 \mathrm{E}-04$ & 211470 & 0.322483 \\
\hline Up & RORA & 14 & 0.001493 & 299584 & 0.282187 \\
\hline Up & LARP1B & 14 & 0.004683 & 546700 & 0.321708 \\
\hline Up & ACSL4 & 14 & 0.005208 & 423594 & 0.320388 \\
\hline Up & ESRRG & 14 & 0.001317 & 573474 & 0.244687 \\
\hline Up & MXD1 & 13 & $6.21 \mathrm{E}-04$ & 548286 & 0.273427 \\
\hline Up & GET4 & 13 & 0.001988 & 297146 & 0.321113 \\
\hline Up & NFE2 & 13 & 0.001758 & 361494 & 0.277475 \\
\hline Up & SCNN1B & 13 & 0.001794 & 293352 & 0.321863 \\
\hline Up & TBX3 & 11 & 0.00107 & 660104 & 0.254826 \\
\hline Up & TAF1B & 11 & 0.00167 & 339720 & 0.323106 \\
\hline Up & $\mathrm{ADK}$ & 11 & 0.003862 & 318638 & 0.320257 \\
\hline Up & CLK3 & 11 & 0.001752 & 276054 & 0.272997 \\
\hline Up & PELI1 & 10 & 0.001025 & 246998 & 0.322195 \\
\hline Up & PHYHIPL & 2 & $1.23 \mathrm{E}-05$ & 3410 & 0.238801 \\
\hline Up & MAFF & 2 & $8.27 \mathrm{E}-06$ & 5370 & 0.260986 \\
\hline Up & TESK2 & 2 & $1.97 \mathrm{E}-05$ & 2606 & 0.259425 \\
\hline Up & MTMR4 & 1 & 0 & 0 & 0.259138 \\
\hline Up & ZFAND6 & 1 & 0 & 0 & 0.230519 \\
\hline Up & ACP1 & 1 & 0 & 0 & 0.27858 \\
\hline Up & EFS & 1 & 0 & 0 & 0.27858 \\
\hline Up & RAB11FIP5 & 1 & 0 & 0 & 0.220331 \\
\hline Up & CYP11A1 & 1 & 0 & 0 & 0.187328 \\
\hline Up & ADAM12 & 1 & 0 & 0 & 0.230951 \\
\hline Up & FBXO9 & 1 & 0 & 0 & 0.25419 \\
\hline Up & HSPB8 & 1 & 0 & 0 & 0.254674 \\
\hline Up & CCNDBP1 & 1 & 0 & 0 & 0.256234 \\
\hline Up & LTBP3 & 1 & 0 & 0 & 0.217731 \\
\hline Up & FNTA & 1 & 0 & 0 & 0.246424 \\
\hline Up & ACOX3 & 1 & 0 & 0 & 0.24266 \\
\hline Up & PJA1 & 1 & 0 & 0 & 0.24372 \\
\hline Up & SERTAD4 & 1 & 0 & 0 & 0.247308 \\
\hline Up & EID2 & 1 & 0 & 0 & 0.259138 \\
\hline Up & AKTIP & 1 & 0 & 0 & 0.254951 \\
\hline Up & SPTLC3 & 1 & 0 & 0 & 0.242911 \\
\hline Up & SGSM1 & 1 & 0 & 0 & 0.246424 \\
\hline Up & LRRC69 & 1 & 0 & 0 & 0.292236 \\
\hline Down & FYN & 305 & 0.060673 & 15146282 & 0.386124 \\
\hline Down & ABL1 & 256 & 0.044808 & 14298188 & 0.385806 \\
\hline Down & SMAD3 & 209 & 0.042609 & 22810928 & 0.349754 \\
\hline Down & STAT3 & 202 & 0.037341 & 10226766 & 0.378422 \\
\hline Down & PRKCA & 182 & 0.041662 & 11865040 & 0.377234 \\
\hline Down & ACTA2 & 161 & 0.02569 & 7462512 & 0.366351 \\
\hline Down & YWHAH & 149 & 0.028069 & 10474112 & 0.350015 \\
\hline Down & ACTG2 & 131 & 0.011051 & 3779892 & 0.354141 \\
\hline Down & RPL14 & 127 & 0.022838 & 13966136 & 0.331377 \\
\hline Down & PDGFRB & 123 & 0.013902 & 4225738 & 0.358778 \\
\hline Down & CCND1 & 119 & 0.017659 & 8841110 & 0.344483 \\
\hline Down & PPM1F & 119 & 0.016265 & 6535610 & 0.32041 \\
\hline Down & CAV1 & 113 & 0.018938 & 4593828 & 0.368628 \\
\hline Down & YWHAQ & 101 & 0.013637 & 4845932 & 0.355674 \\
\hline Down & FOXO1 & 96 & 0.015104 & 5652522 & 0.349128 \\
\hline Down & WNT3A & 95 & 0.013629 & 4052094 & 0.299674 \\
\hline Down & RHOQ & 92 & 0.016733 & 3678142 & 0.331471 \\
\hline Down & TUBB2A & 91 & 0.012587 & 3886552 & 0.334213 \\
\hline Down & FGFR3 & 83 & 0.010949 & 3642512 & 0.326755 \\
\hline Down & RARA & 81 & 0.013223 & 4465300 & 0.341869 \\
\hline Down & MYH11 & 72 & 0.01194 & 3062450 & 0.35249 \\
\hline Down & HIPK2 & 72 & 0.01135 & 3565432 & 0.339639 \\
\hline Down & HSPA12B & 68 & 0.003037 & 744544 & 0.301991 \\
\hline Down & RPS6KA2 & 68 & 0.005549 & 2522498 & 0.317738 \\
\hline Down & TEK & 66 & 0.004665 & 1653094 & 0.338168 \\
\hline Down & NCOA1 & 65 & 0.008395 & 3153458 & 0.31475 \\
\hline Down & VCL & 63 & 0.009681 & 2780132 & 0.338217 \\
\hline Down & TUBB2B & 62 & 0.00676 & 1694194 & 0.343977 \\
\hline Down & PPP2R2B & 62 & 0.010479 & 4191976 & 0.328542 \\
\hline Down & TPM2 & 62 & 0.006776 & 1763750 & 0.334428 \\
\hline Down & SPTAN1 & 62 & 0.011399 & 2596256 & 0.334046 \\
\hline
\end{tabular}


bioRxiv preprint doi: https://doi.org/10.1101/2021.03.09.434569; this version posted March 10, 2021. The copyright holder for this preprint (which was not certified by peer review) is the author/funder. All rights reserved. No reuse allowed without permission.

\begin{tabular}{|c|c|c|c|c|c|}
\hline Down & MYL9 & 60 & 0.008098 & 2479906 & 0.335361 \\
\hline Down & DIMT1 & 58 & 0.008481 & 2242228 & 0.327326 \\
\hline Down & TCF4 & 54 & 0.009445 & 2760706 & 0.330629 \\
\hline Down & MRPL34 & 52 & 0.006656 & 17810170 & 0.236106 \\
\hline Down & CCND3 & 51 & 0.003239 & 1601134 & 0.295927 \\
\hline Down & LMNA & 47 & 0.00911 & 2401846 & 0.338682 \\
\hline Down & PKN1 & 46 & 0.003592 & 1349794 & 0.299559 \\
\hline Down & CD44 & 46 & 0.010187 & 2270300 & 0.349493 \\
\hline Down & DCN & 45 & 0.007594 & 1930616 & 0.322283 \\
\hline Down & ADCY3 & 45 & 0.008618 & 1694556 & 0.33133 \\
\hline Down & TGFB1I1 & 45 & 0.003137 & 931752 & 0.325349 \\
\hline Down & EPHA3 & 44 & 0.002379 & 661600 & 0.318884 \\
\hline Down & FZD4 & 43 & 0.005096 & 1738748 & 0.327006 \\
\hline Down & RND3 & 42 & 0.006152 & 1123788 & 0.333832 \\
\hline Down & ADCY4 & 41 & 0.001819 & 672196 & 0.287785 \\
\hline Down & ETS2 & 41 & 0.004246 & 1834106 & 0.329559 \\
\hline Down & RAP2A & 40 & 0.007351 & 1433240 & 0.326983 \\
\hline Down & CCND2 & 40 & 0.002601 & 1155154 & 0.334046 \\
\hline Down & AXIN2 & 39 & 0.00394 & 1203884 & 0.333618 \\
\hline Down & OPTN & 37 & 0.00695 & 1707428 & 0.328289 \\
\hline Down & UBE2L6 & 37 & 0.005601 & 1462120 & 0.327189 \\
\hline Down & PIP5K1C & 37 & 0.002815 & 1263578 & 0.334714 \\
\hline Down & MAP1B & 34 & 0.007029 & 1488054 & 0.325371 \\
\hline Down & AXL & 34 & 0.002374 & 729250 & 0.345881 \\
\hline Down & IRAK3 & 33 & $8.12 \mathrm{E}-04$ & 865022 & 0.277229 \\
\hline Down & FLNA & 33 & 0.004649 & 1087030 & 0.310146 \\
\hline Down & COL1A1 & 32 & 0.008312 & 1395294 & 0.32942 \\
\hline Down & DLL1 & 31 & 0.006383 & 1006300 & 0.324583 \\
\hline Down & JAG1 & 29 & 0.005281 & 874336 & 0.325033 \\
\hline Down & PDE9A & 29 & 0.003164 & 644058 & 0.281577 \\
\hline Down & AGTR1 & 28 & 0.004101 & 926250 & 0.304088 \\
\hline Down & TNNT3 & 27 & $1.64 \mathrm{E}-04$ & 89708 & 0.268585 \\
\hline Down & MYO10 & 27 & 0.002183 & 551478 & 0.325892 \\
\hline Down & GPC4 & 26 & 0.001618 & 1207760 & 0.258652 \\
\hline Down & IGFBP3 & 26 & 0.004163 & 894182 & 0.300288 \\
\hline Down & ABCE1 & 25 & 0.007191 & 831802 & 0.321973 \\
\hline Down & TIMP1 & 23 & 0.006574 & 950444 & 0.322905 \\
\hline Down & VTN & 23 & 0.005502 & 970948 & 0.284138 \\
\hline Down & ARAP3 & 23 & $8.48 \mathrm{E}-04$ & 298776 & 0.326642 \\
\hline Down & COL1A2 & 23 & 0.001462 & 373484 & 0.28554 \\
\hline Down & B2M & 23 & 0.00758 & 619198 & 0.322505 \\
\hline Down & TBCB & 22 & 0.002726 & 428028 & 0.322705 \\
\hline Down & VASN & 22 & 0.003962 & 582444 & 0.343574 \\
\hline Down & LGALS1 & 21 & 0.004371 & 578082 & 0.333903 \\
\hline Down & CD81 & 21 & 0.005039 & 710796 & 0.323708 \\
\hline Down & VCAM1 & 21 & 0.003333 & 2717522 & 0.2699 \\
\hline Down & THY1 & 21 & 0.003795 & 675432 & 0.288956 \\
\hline Down & PHGDH & 21 & 0.004117 & 689964 & 0.323999 \\
\hline Down & ITPR3 & 21 & 0.003472 & 727920 & 0.327326 \\
\hline Down & TGFB3 & 20 & 0.002631 & 725004 & 0.278316 \\
\hline Down & BIN1 & 20 & 0.002083 & 351704 & 0.291835 \\
\hline Down & LPAR1 & 20 & 0.001469 & 1296676 & 0.242258 \\
\hline Down & MSX1 & 20 & 0.003633 & 648486 & 0.289134 \\
\hline Down & SLIT2 & 20 & 0.001084 & 281232 & 0.291273 \\
\hline Down & SHMT2 & 19 & 0.005637 & 547666 & 0.32215 \\
\hline Down & COL4A1 & 19 & 0.001742 & 983934 & 0.257813 \\
\hline Down & RAB3IL1 & 19 & 0.002314 & 1857444 & 0.231054 \\
\hline Down & SPARC & 17 & 0.002023 & 197820 & 0.275923 \\
\hline Down & VCAN & 17 & 0.003487 & 561304 & 0.267405 \\
\hline Down & LDB2 & 17 & 0.003396 & 1291388 & 0.254812 \\
\hline Down & DPYSL2 & 17 & 0.003321 & 506826 & 0.325869 \\
\hline Down & MAF & 17 & 0.001088 & 288082 & 0.289456 \\
\hline Down & PARVA & 16 & 0.003041 & 421786 & 0.323731 \\
\hline Down & TNFRSF1B & 16 & 0.001419 & 325188 & 0.32382 \\
\hline Down & FBLN2 & 16 & 0.001835 & 589690 & 0.249987 \\
\hline Down & EEF2K & 15 & 0.001411 & 364288 & 0.323083 \\
\hline Down & TEAD2 & 15 & 7.99E-04 & 352390 & 0.324066 \\
\hline Down & TAGLN & 15 & 0.001241 & 205764 & 0.280381 \\
\hline Down & FASN & 15 & 0.001757 & 367956 & 0.322084 \\
\hline Down & CD36 & 15 & 0.002116 & 386412 & 0.294661 \\
\hline
\end{tabular}


bioRxiv preprint doi: https://doi.org/10.1101/2021.03.09.434569; this version posted March 10, 2021. The copyright holder for this preprint (which was not certified by peer review) is the author/funder. All rights reserved. No reuse allowed without permission.

\begin{tabular}{|c|c|c|c|c|c|}
\hline Down & NDN & 15 & 0.003831 & 473694 & 0.322239 \\
\hline Down & ADAM15 & 15 & 0.001982 & 294010 & 0.331283 \\
\hline Down & ARHGEF2 & 15 & $9.41 \mathrm{E}-04$ & 262426 & 0.330396 \\
\hline Down & PEMT & 14 & 0.005116 & 629532 & 0.293664 \\
\hline Down & VWF & 14 & 0.001828 & 345586 & 0.275097 \\
\hline Down & OXTR & 14 & 0.001359 & 1221820 & 0.23325 \\
\hline Down & FRYL & 14 & 0.001994 & 332012 & 0.321598 \\
\hline Down & AGRN & 14 & 0.001733 & 263834 & 0.326482 \\
\hline Down & LFNG & 13 & 0.001654 & 331212 & 0.264357 \\
\hline Down & ARHGEF6 & 13 & 0.001032 & 179796 & 0.326573 \\
\hline Down & TSC22D3 & 13 & $1.34 \mathrm{E}-04$ & 119696 & 0.32391 \\
\hline Down & IMPDH1 & 13 & 0.002712 & 390200 & 0.321554 \\
\hline Down & NME4 & 12 & 0.003215 & 901430 & 0.228485 \\
\hline Down & EHD2 & 12 & 0.003128 & 309602 & 0.320717 \\
\hline Down & RGL1 & 12 & $5.53 \mathrm{E}-04$ & 670384 & 0.247308 \\
\hline Down & COL18A1 & 12 & 0.001098 & 309928 & 0.266008 \\
\hline Down & ADGRA2 & 12 & $8.13 \mathrm{E}-04$ & 196338 & 0.301583 \\
\hline Down & FMOD & 11 & $2.68 \mathrm{E}-04$ & 98450 & 0.300385 \\
\hline Down & SLIT3 & 10 & $6.95 \mathrm{E}-05$ & 22762 & 0.24207 \\
\hline Down & COL5A1 & 3 & $4.31 \mathrm{E}-05$ & 14682 & 0.244636 \\
\hline Down & TGFBI & 3 & $8.62 \mathrm{E}-06$ & 14986 & 0.248607 \\
\hline Down & RASIP1 & 2 & $1.64 \mathrm{E}-06$ & 1660 & 0.251732 \\
\hline Down & CAV2 & 2 & 0 & 0 & 0.285836 \\
\hline Down & PCOLCE & 2 & $3.25 \mathrm{E}-05$ & 6584 & 0.246761 \\
\hline Down & COL4A2 & 2 & 0 & 0 & 0.208517 \\
\hline Down & SVIL & 2 & 0 & 0 & 0.262801 \\
\hline Down & SMTN & 2 & 7.00E-06 & 2536 & 0.261073 \\
\hline Down & COL4A5 & 2 & $7.45 \mathrm{E}-06$ & 6672 & 0.244776 \\
\hline Down & FSCN1 & 2 & $2.41 \mathrm{E}-06$ & 2090 & 0.268585 \\
\hline Down & ADAMTS1 & 2 & $5.19 \mathrm{E}-05$ & 3268 & 0.250857 \\
\hline Down & CTSC & 1 & 0 & 0 & 0.244559 \\
\hline Down & FEZ1 & 1 & 0 & 0 & 0.21526 \\
\hline Down & MALL & 1 & 0 & 0 & 0.269357 \\
\hline Down & LYL1 & 1 & 0 & 0 & 0.248489 \\
\hline Down & SEMA3A & 1 & 0 & 0 & 0.27858 \\
\hline Down & ENPP2 & 1 & 0 & 0 & 0.195022 \\
\hline Down & BST2 & 1 & 0 & 0 & 0.24757 \\
\hline Down & F3 & 1 & 0 & 0 & 0.236738 \\
\hline Down & COL16A1 & 1 & 0 & 0 & 0.204978 \\
\hline Down & ANGPTL2 & 1 & 0 & 0 & 0.252724 \\
\hline Down & NCALD & 1 & 0 & 0 & 0.250508 \\
\hline Down & RASL12 & 1 & 0 & 0 & 0.228262 \\
\hline Down & PPP1R14A & 1 & 0 & 0 & 0.273923 \\
\hline Down & FCGRT & 1 & 0 & 0 & 0.243872 \\
\hline Down & CNN2 & 1 & 0 & 0 & 0.268139 \\
\hline Down & EHBP1 & 1 & 0 & 0 & 0.242848 \\
\hline Down & COL3A1 & 1 & 0 & 0 & 0.216264 \\
\hline Down & DDIT4 & 1 & 0 & 0 & 0.25408 \\
\hline Down & ITM2C & 1 & 0 & 0 & 0.249441 \\
\hline Down & GAS6 & 1 & 0 & 0 & 0.257007 \\
\hline Down & FERMT2 & 1 & 0 & 0 & 0.252751 \\
\hline Down & RAPGEF5 & 1 & 0 & 0 & 0.246424 \\
\hline Down & APCDD1 & 1 & 0 & 0 & 0.230588 \\
\hline Down & MMP23B & 1 & 0 & 0 & 0.200599 \\
\hline Down & PTPRD & 1 & 0 & 0 & 0.274549 \\
\hline Down & RSPO3 & 1 & 0 & 0 & 0.249441 \\
\hline Down & COL6A1 & 1 & 0 & 0 & 0.243745 \\
\hline Down & DDR2 & 1 & 0 & 0 & 0.247805 \\
\hline Down & NEK6 & 1 & 0 & 0 & 0.244776 \\
\hline Down & COL5A2 & 1 & 0 & 0 & 0.205788 \\
\hline Down & TSPAN4 & 1 & 0 & 0 & 0.244559 \\
\hline Down & IFITM3 & 1 & 0 & 0 & 0.27858 \\
\hline Down & HES4 & 1 & 0 & 0 & 0.261875 \\
\hline Down & FAT1 & 1 & 0 & 0 & 0.242521 \\
\hline
\end{tabular}

Table 6 miRNA - hub gene and TF - hub gene interaction 


\begin{tabular}{|c|c|c|c|c|c|c|c|}
\hline Up & UBE2D3 & 189 & hsa-mir-6127 & Up & HSP90AA1 & 45 & E2F1 \\
\hline Up & HSP90AA1 & 188 & hsa-let-7d-5p & Up & UBE2D3 & 43 & HCFC1 \\
\hline $\mathrm{Up}$ & PAK2 & 158 & hsa-mir-8063 & Up & EGFR & 39 & SRY \\
\hline Up & DDB1 & 108 & hsa-mir-329-3p & Up & PSMC4 & 34 & ZFX \\
\hline Up & DVL3 & 104 & hsa-mir-1207-5p & Up & DDB1 & 32 & RUNX1 \\
\hline Up & EGFR & 83 & hsa-mir-181a-2-3p & Up & STAT5B & 28 & ESR1 \\
\hline Up & UBE2A & 60 & hsa-mir-5700 & Up & PAK2 & 27 & REST \\
\hline Up & PSMC4 & 47 & hsa-mir-665 & Up & RBX1 & 27 & YY1 \\
\hline Up & CSNK2A2 & 45 & hsa-mir-30d-3p & Up & STX5 & 24 & SREBF2 \\
\hline Up & STAT5B & 42 & hsa-mir-1343-3p & Up & CSNK2A2 & 21 & SIN3A \\
\hline Up & PAK1 & 31 & hsa-mir-629-3p & Up & RPS13 & 19 & ASH2L \\
\hline Up & RBX1 & 29 & hsa-mir-4513 & Up & SMARCB1 & 18 & EGR1 \\
\hline Up & SMARCB1 & 21 & hsa-mir-192-5p & Up & DVL3 & 17 & TTF2 \\
\hline Up & STX5 & 15 & hsa-mir-146a-5p & Up & PAK1 & 16 & ТР63 \\
\hline Up & RPS13 & 10 & hsa-mir-15b-3p & Up & UBE2A & 11 & TRIM28 \\
\hline Down & CCND1 & 396 & hsa-mir-4651 & Down & STAT3 & 67 & SPI1 \\
\hline Down & STAT3 & 148 & hsa-mir-410-5p & Down & CCND1 & 56 & MYBL2 \\
\hline Down & FOXO1 & 124 & hsa-mir-222-3p & Down & SMAD3 & 53 & SUZ12 \\
\hline Down & CAV1 & 115 & hsa-mir-29c-3p & Down & FOXO1 & 44 & TBX3 \\
\hline Down & ABL1 & 112 & hsa-mir-663a & Down & PRKCA & 43 & YAP1 \\
\hline Down & YWHAH & 112 & hsa-mir-577 & Down & ABL1 & 40 & TEAD4 \\
\hline Down & YWHAQ & 111 & hsa-mir-16-2-3p & Down & FYN & 39 & CEBPD \\
\hline Down & RPL14 & 99 & hsa-mir-3960 & Down & YWHAQ & 38 & SOX9 \\
\hline Down & PPM1F & 99 & hsa-mir-638 & Down & CAV1 & 36 & BMI1 \\
\hline Down & SMAD3 & 78 & hsa-mir-744-5p & Down & YWHAH & 31 & RCOR3 \\
\hline Down & PRKCA & 67 & hsa-mir-6727-3p & Down & RPL14 & 29 & $\mathrm{LMO} 2$ \\
\hline Down & FYN & 61 & hsa-mir-429 & Down & PDGFRB & 28 & TAL1 \\
\hline Down & ACTA2 & 42 & hsa-mir-376c-3p & Down & PPM1F & 18 & FOXP1 \\
\hline Down & PDGFRB & 28 & hsa-mir-101-3p & Down & ACTA2 & 14 & E2F4 \\
\hline Down & ACTG2 & 10 & hsa-mir-103a-3p & Down & ACTG2 & 8 & CUX1 \\
\hline
\end{tabular}

Table 7. Docking results of designed molecules on over expressed proteins

\begin{tabular}{|c|c|c|c|c|c|c|c|c|c|c|c|c|}
\hline \multirow{3}{*}{$\begin{array}{l}\text { Sl. No/ } \\
\text { Code }\end{array}$} & \multicolumn{3}{|c|}{ EGFR } & \multicolumn{3}{|c|}{ HSP90AA1 } & \multicolumn{3}{|c|}{ PAK1 } & \multicolumn{3}{|c|}{ RBX1 } \\
\hline & \multicolumn{3}{|c|}{ PDB: 4UV7 } & \multicolumn{3}{|c|}{ PDB:5NJX } & \multicolumn{3}{|c|}{ PDB: 3Q4Z } & \multicolumn{3}{|c|}{ PDB: 3FN1 } \\
\hline & $\begin{array}{l}\text { Binding } \\
\text { Energy }\end{array}$ & $\begin{array}{c}\text {-Cdocker } \\
\text { Energy }\end{array}$ & $\begin{array}{c}\text { - Cdocker } \\
\text { Interaction } \\
\text { Energy }\end{array}$ & $\begin{array}{l}\text { Binding } \\
\text { Energy }\end{array}$ & $\begin{array}{c}\text {-Cdocker } \\
\text { Energy }\end{array}$ & $\begin{array}{c}\text { - Cdocker } \\
\text { Interaction } \\
\text { Energy }\end{array}$ & $\begin{array}{l}\text { Binding } \\
\text { Energy }\end{array}$ & $\begin{array}{c}\text {-Cdocker } \\
\text { Energy }\end{array}$ & $\begin{array}{c}\text { - Cdocker } \\
\text { Interaction } \\
\text { Energy } \\
\end{array}$ & $\begin{array}{c}\text { Binding } \\
\text { Energy }\end{array}$ & $\begin{array}{c}\text {-Cdocker } \\
\text { Energy } \\
\end{array}$ & $\begin{array}{c}\text { - Cdocker } \\
\text { Interaction } \\
\text { Energy }\end{array}$ \\
\hline AJA & -56.02 & -10.57 & 18.17 & -77.05 & -6.93 & 21.66 & -196.65 & 13.03 & 43.86 & -113.94 & 5.61 & 37.90 \\
\hline ALE & -22.04 & -17.45 & 10.55 & -16.93 & -16.44 & 12.00 & -58.34 & -2.81 & 24.49 & -24.28 & -9.71 & 18.84 \\
\hline ALO & -6.22 & -25.19 & 8.57 & -2.69 & -24.11 & 9.65 & -4.41 & -19.09 & 14.60 & -11.36 & -18.02 & 15.96 \\
\hline ARA & -50.94 & -28.62 & 19.50 & -57.53 & -18.31 & 26.43 & -159.25 & 8.76 & 57.02 & -83.85 & -16.52 & 33.54 \\
\hline ARJ & -43.98 & 17.23 & 28.38 & -39.56 & 18.14 & 25.73 & -119.99 & 33.00 & 43.82 & -39.87 & 26.58 & 31.46 \\
\hline ARG & -49.90 & 20.57 & 23.74 & -61.58 & 22.29 & 25.37 & -151.03 & 40.87 & 47.08 & -7.21 & -116.32 & 22.65 \\
\hline ANA & -65.59 & -68.87 & 32.04 & -89.71 & -66.11 & 51.76 & -245.05 & -79.05 & 83.86 & -61.60 & 21.05 & 41.01 \\
\hline ALL & -118.34 & -47.02 & 34.21 & -168.97 & -50.42 & 39.91 & -139.90 & -23.49 & 62.54 & -18.62 & -15.64 & 14.90 \\
\hline CAR & -86.83 & 19.53 & 35.26 & -45.09 & 19.64 & 36.45 & -131.24 & 37.17 & 58.34 & -48.59 & -55.20 & 21.22 \\
\hline CAJ & -6.67 & -21.05 & 9.42 & -6.26 & -20.34 & 10.30 & -9.30 & -16.06 & 13.09 & -47.54 & 28.64 & 30.02 \\
\hline CAP & -35.79 & -58.29 & 19.06 & -42.81 & -50.54 & 28.01 & -172.32 & -28.95 & 57.88 & -6.63 & -25.87 & 30.85 \\
\hline CAV & -65.69 & 22.19 & 25.24 & -53.63 & 25.00 & 27.33 & -136.49 & 43.84 & 47.47 & -46.65 & 19.83 & 28.55 \\
\hline $\mathrm{CHA}$ & -4.05 & -30.55 & 21.32 & -35.08 & -30.24 & 21.35 & -107.73 & -7.42 & 44.11 & -27.07 & 13.28 & 14.79 \\
\hline
\end{tabular}




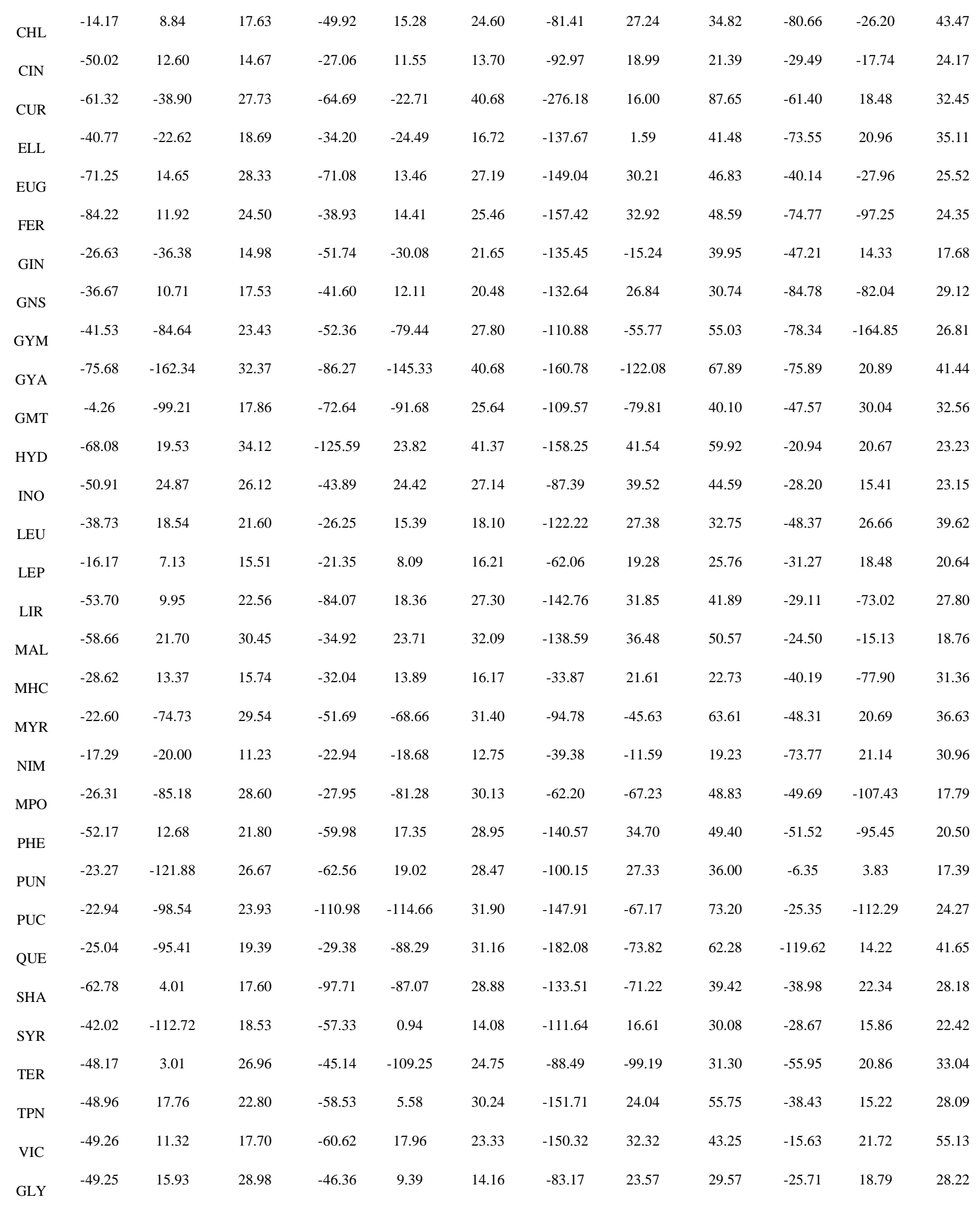


bioRxiv preprint doi: https://doi.org/10.1101/2021.03.09.434569; this version posted March 10, 2021. The copyright holder for this preprint (which was not certified by peer review) is the author/funder. All rights reserved. No reuse allowed without permission.

MET

18.35

32.89

$-25.62$

34.77

17.74

$-196.65$

13.03

43.86

$-61.04$

\section{Figures}

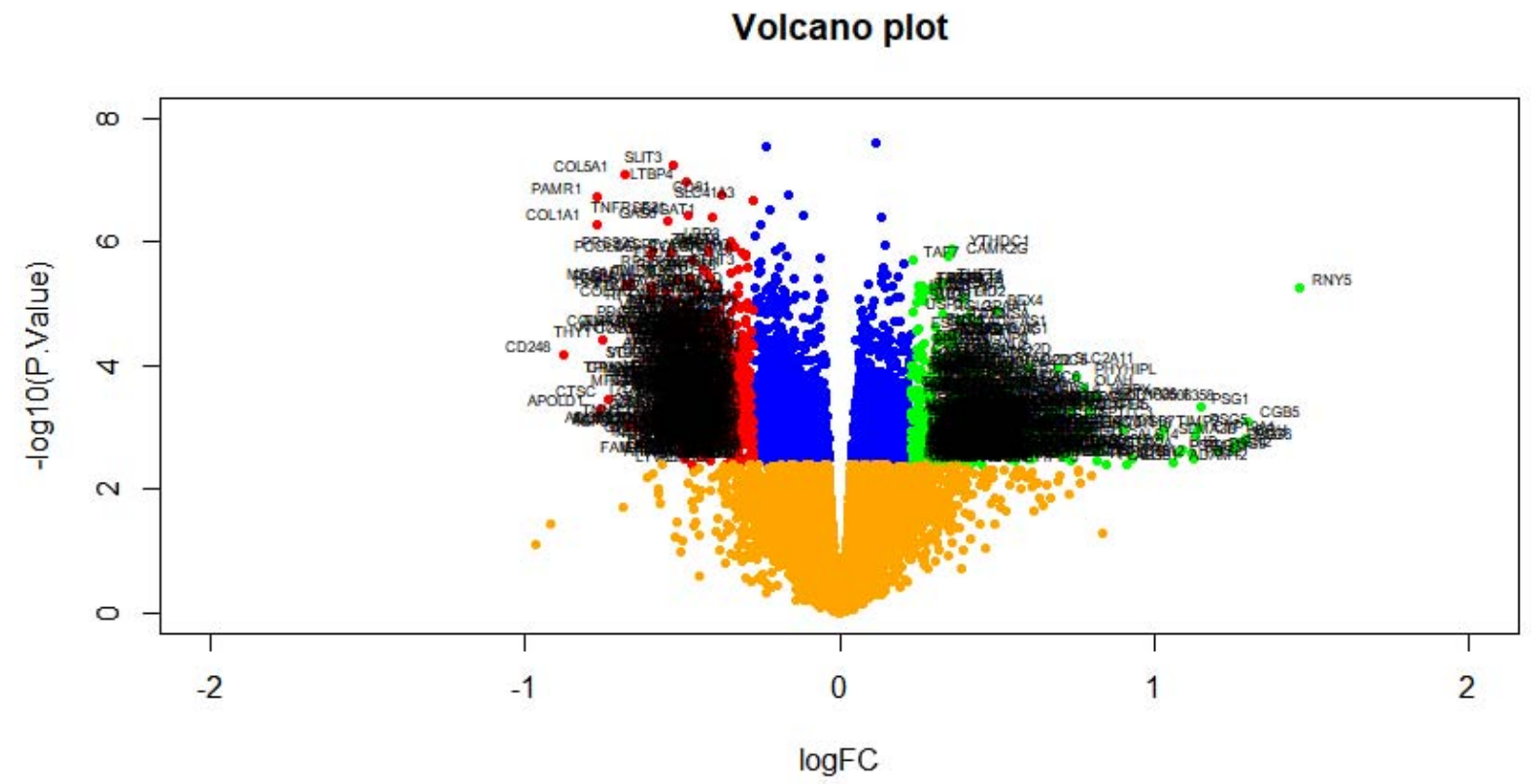

Fig. 1. Volcano plot of differentially expressed genes. Genes with a significant change of more than two-fold were selected. Green dot represented up regulated significant genes and red dot represented down regulated significant genes. 
bioRxiv preprint doi: https://doi.org/10.1101/2021.03.09.434569; this version posted March 10, 2021. The copyright holder for this preprint (which was not certified by peer review) is the author/funder. All rights reserved. No reuse allowed without permission.
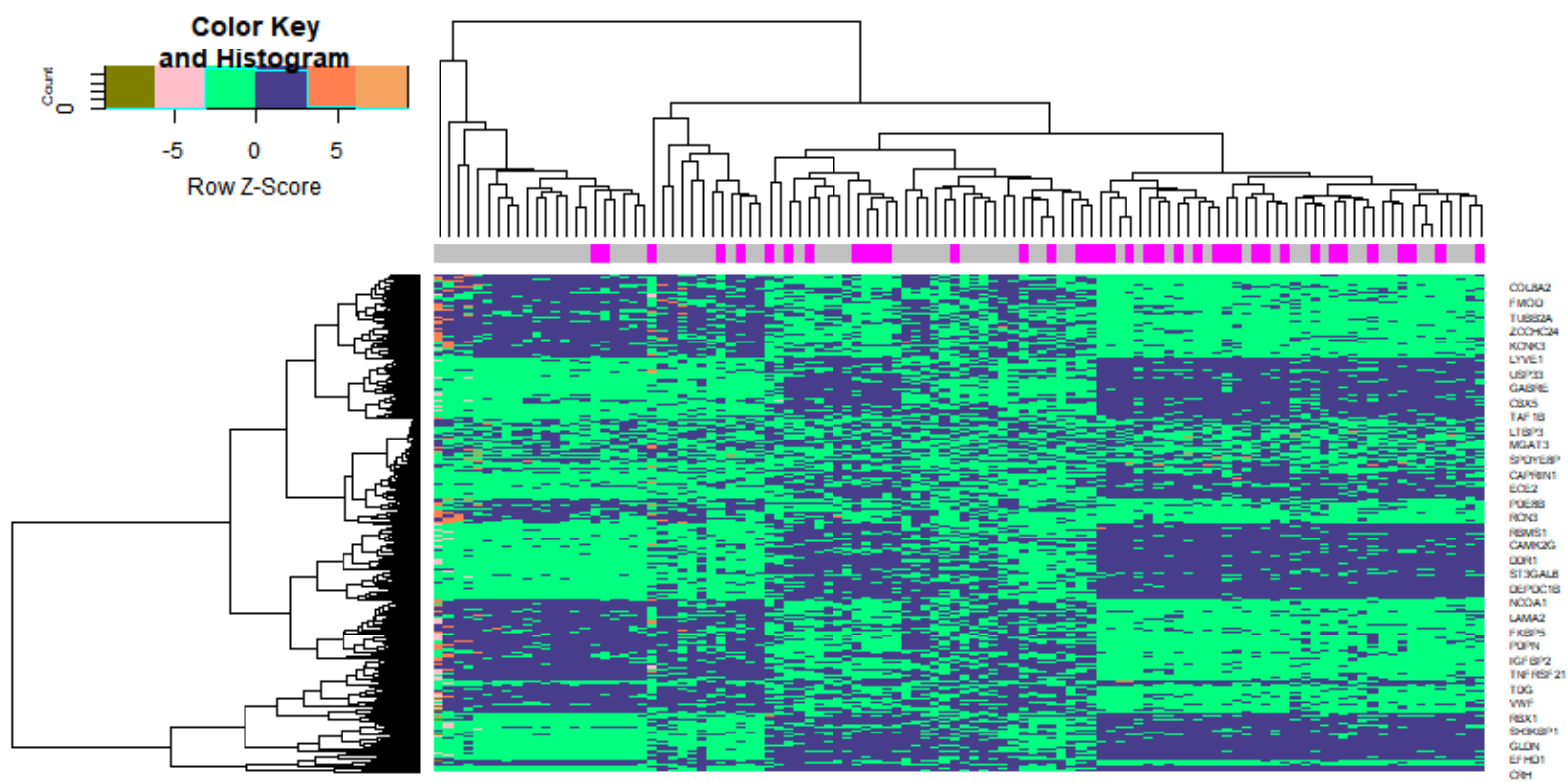

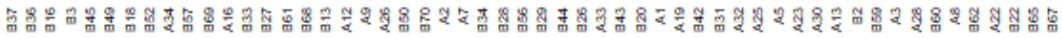

Fig. 2. Heat map of differentially expressed genes. Legend on the top left indicate log fold change of genes. (A1 $\mathrm{A} 38=$ Gestational diabetes mellitus; $\mathrm{B} 1-\mathrm{B} 70=$ Gestational diabetes mellitus $)$

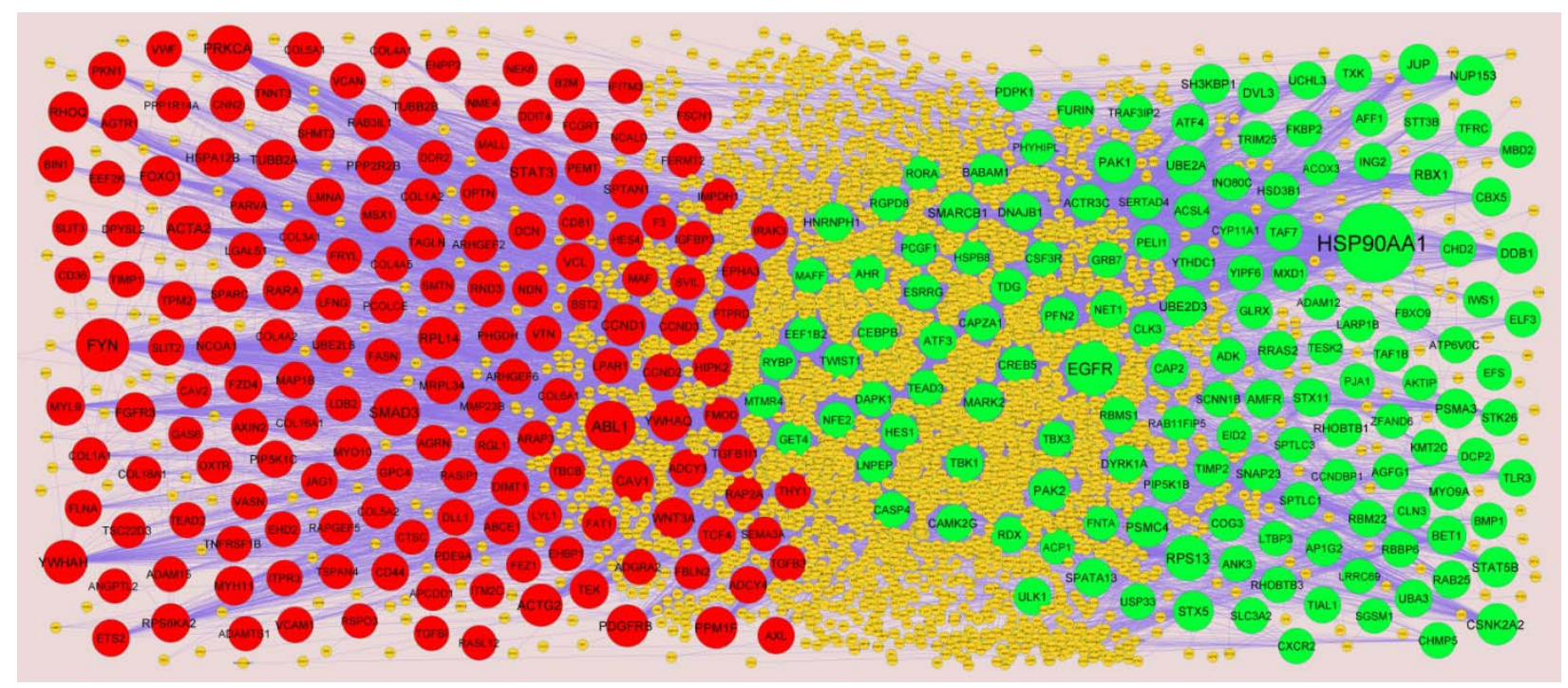

Fig. 3. PPI network of DEGs. The PPI network of DEGs was constructed using Cytoscap. Up regulated genes are marked in green; down regulated genes are marked in red 
bioRxiv preprint doi: https://doi.org/10.1101/2021.03.09.434569; this version posted March 10, 2021. The copyright holder for this preprint (which was not certified by peer review) is the author/funder. All rights reserved. No reuse allowed without permission.

A

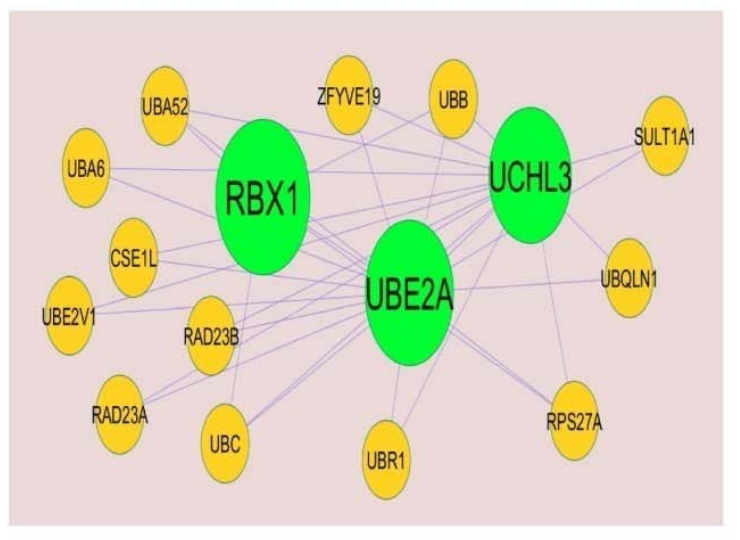

B

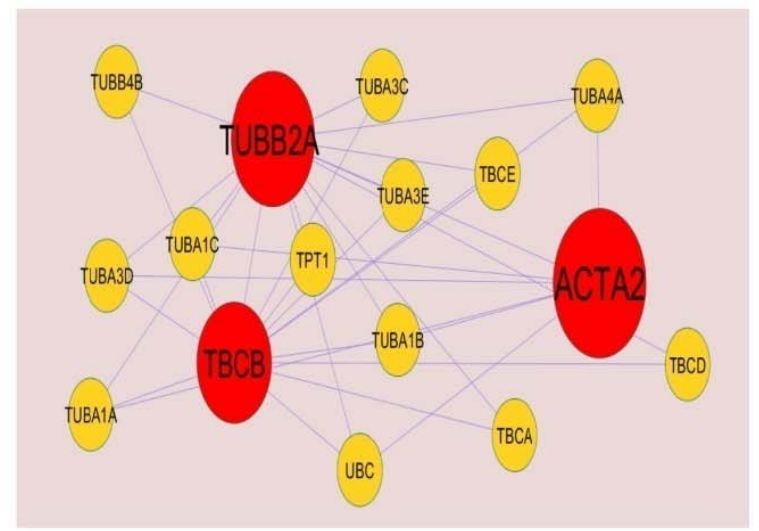

Fig. 4. Modules of isolated form PPI of DEGs. (A) The most significant module was obtained from PPI network with 16 nodes and 32 edges for up regulated genes (B) The most significant module was obtained from PPI network with 16 nodes and 34 edges for down regulated genes. Up regulated genes are marked in green; down regulated genes are marked in red.

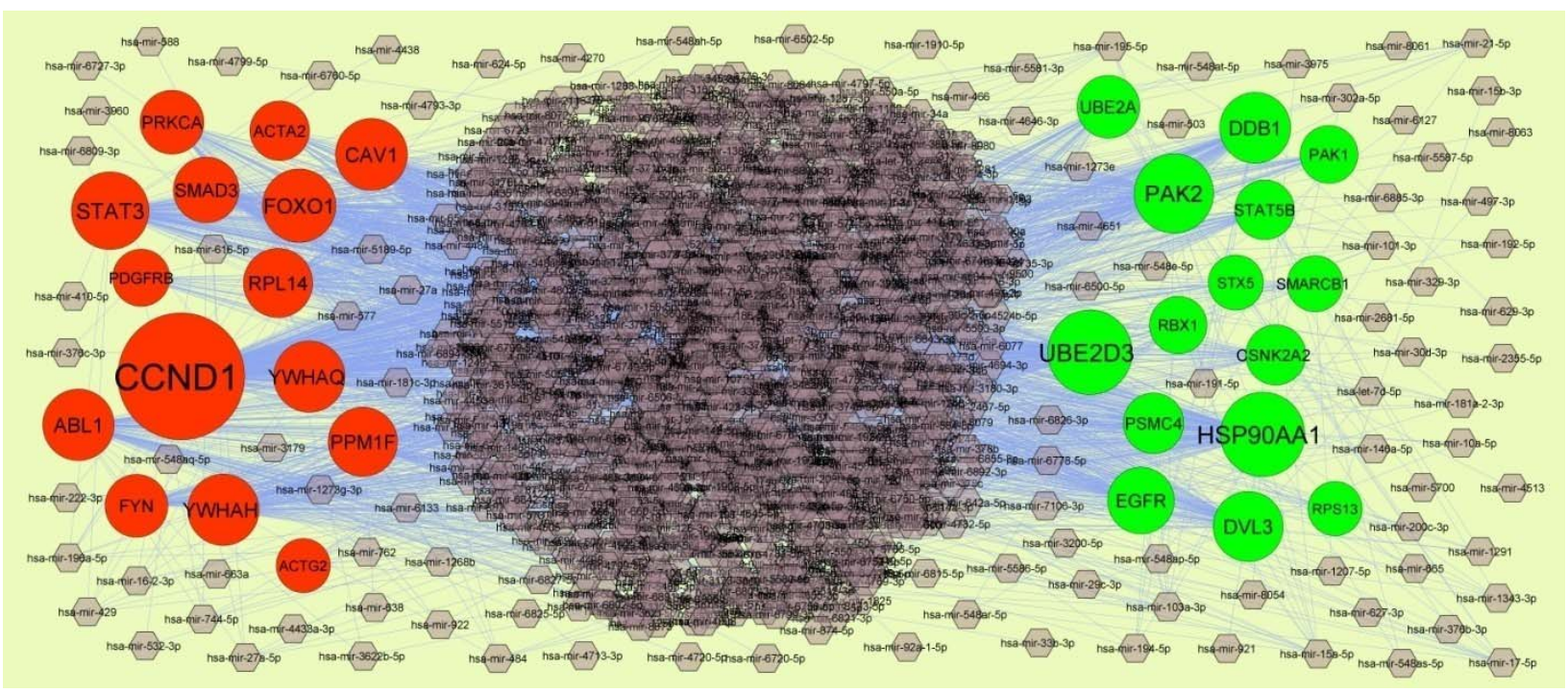

Fig. 5. MiRNA - hub gene regulatory network. The light purple color diamond nodes represent the key miRNAs; up regulated genes are marked in green; down regulated genes are marked in red. 


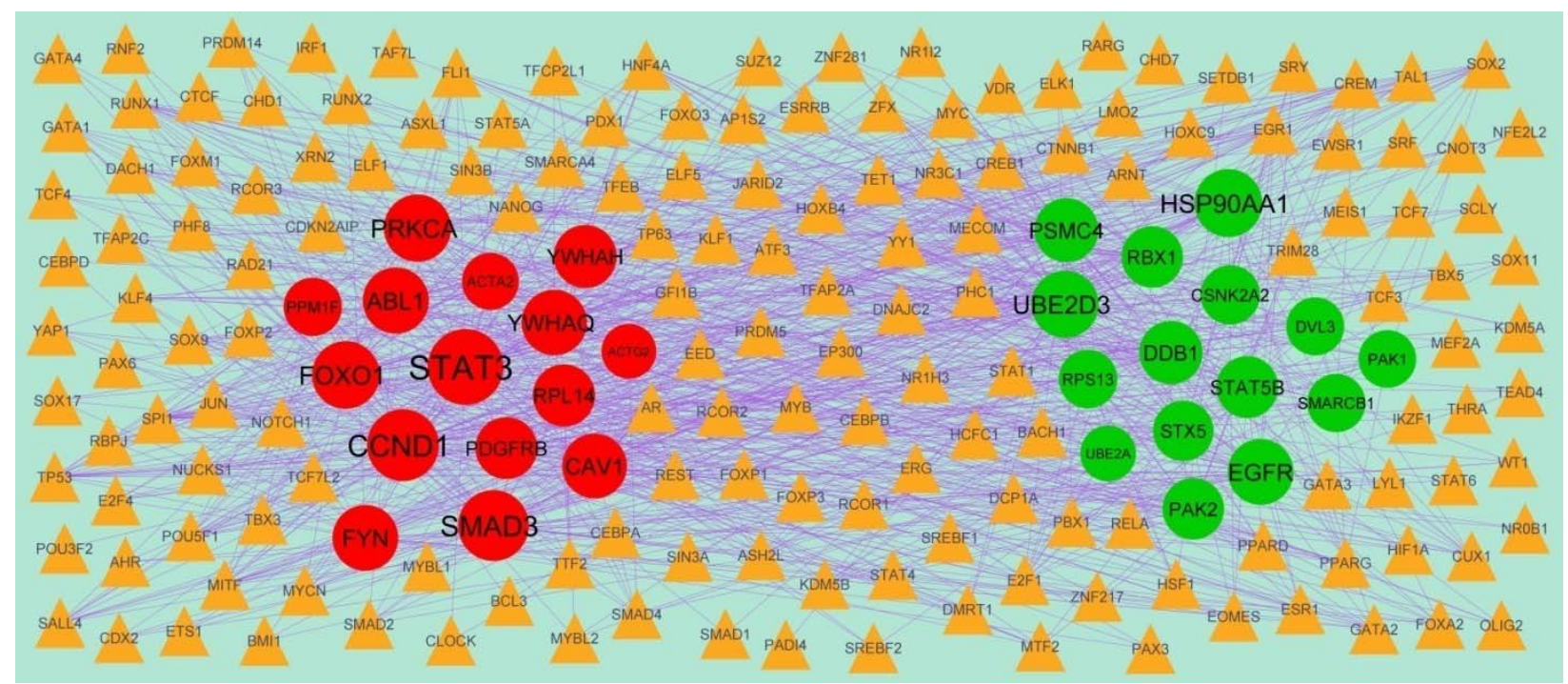

Fig. 6. TF - hub gene regulatory network. The yellow color triangle nodes represent the key TFs; up regulated genes are marked in green; down regulated genes are marked in red.
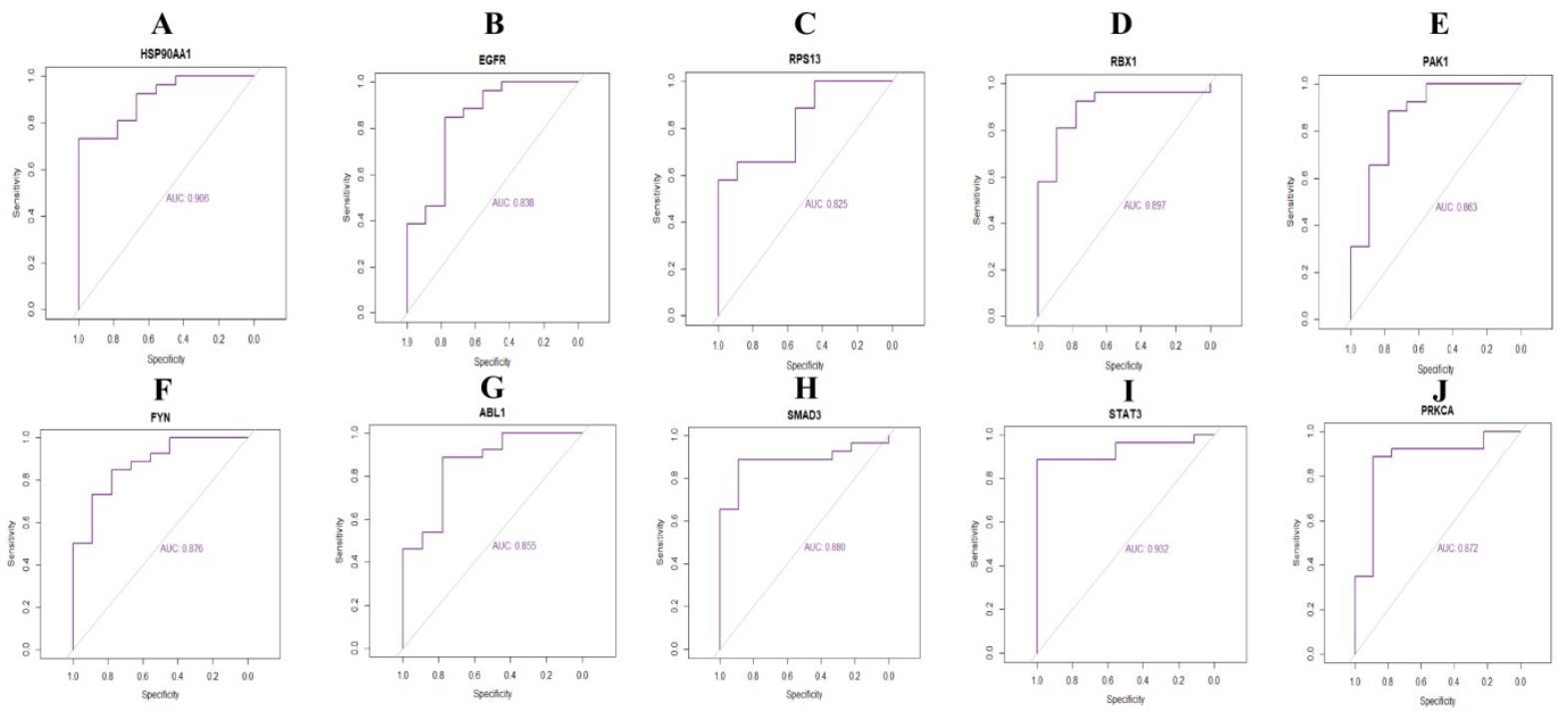

Fig. 7 ROC curve validated the sensitivity, specificity of hub genes as a predictive biomarker for GDM prognosis. A) HSP90AA1 B) EGFR C) RPS13 D) RBX1 E) PAK1 F) FYN G) ABL1 H) SMAD3 I) STAT3 J) PRKCA 
A

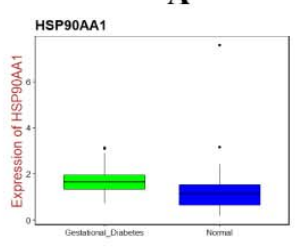

F

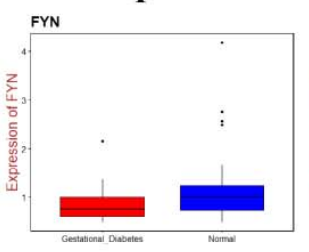

Normal
B

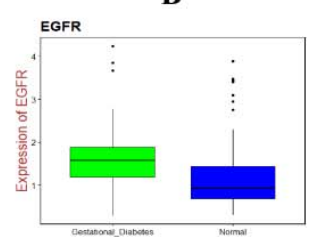

G

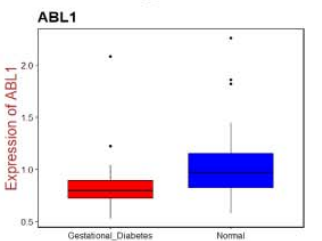

C

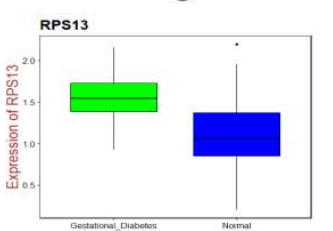

H

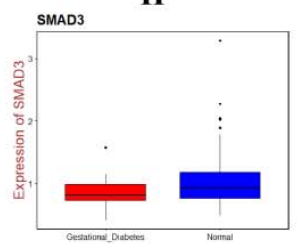

D

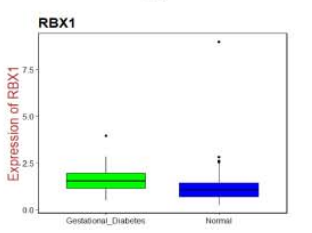

I

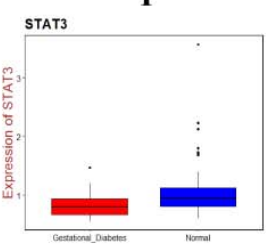

$\mathbf{E}$

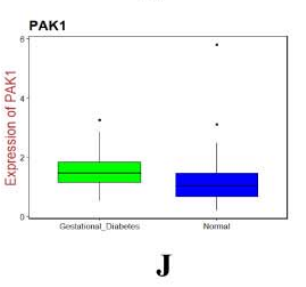

PRKCA

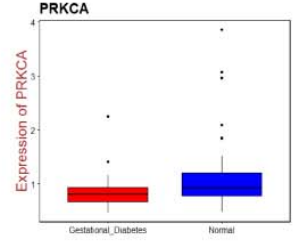

GDM (Down regulated genes)

Fig. 8 Validation of hub genes by RT- PCR. A) HSP90AA1 B) EGFR C) RPS13 D) RBX1 E) PAK1 F) FYN G) ABL1 H) SMAD3 I) STAT3 J) PRKCA 
<smiles>C=CCS(=O)CC(N)C(=O)O</smiles><smiles>CC(=O)Oc1cccc2c1C(=O)c1c(O)cc(CO)cc1C2=O</smiles>

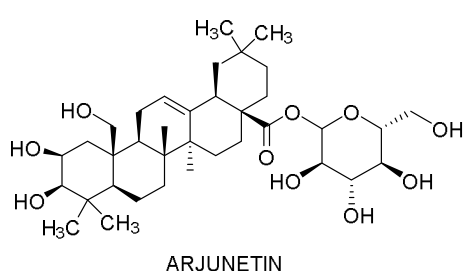
ARJUNETIN

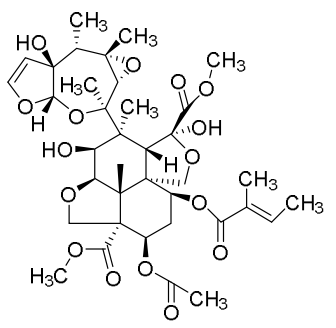<smiles>COc1cc(O)c2c(=O)c(-c3ccc(O)cc3O)coc2c1</smiles>

$\mathrm{OH}$

ARJUNGENIN<smiles>CCc1ccc2c(c1)C1c3ccccc3C(O)C(OC(O)C(O)C(O)C(O)C2O)C1O</smiles><smiles>CC1OC2OC1C(O)C2O</smiles>

ARABIC_ACID

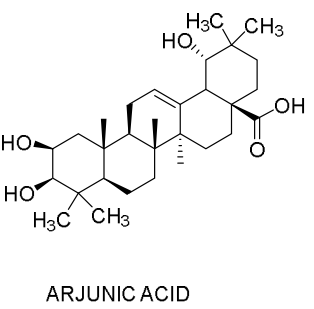

ARJUNIC ACID<smiles>O=C(O)/C=C/c1ccccc1</smiles>
$\mathrm{H}_{3} \mathrm{C}$ CAPSAICIN<smiles>CC(/C=C/C=C(C)/C=C/C=C(C)/C=C/C=C(C)/C=C/C=C(C)/C=C/C1=C(C)CCCC1(C)C)=C(N)C#N</smiles><smiles>C=C(C)[C@H]1CC=C(C)C(=O)C1</smiles>
CINNAMIC_ACID<smiles>O=C(O)OC1C[C@@](O)(C(=O)O)C[C@H](O)[C@H]1O</smiles><smiles>C=CCc1ccc(O)c(CC)c1</smiles>
EUGENOL CHLOROGENIC_ACID OH<smiles>CCOC(=O)C(C)=O</smiles>
FERULIC_ACID ELLAGIC ACID

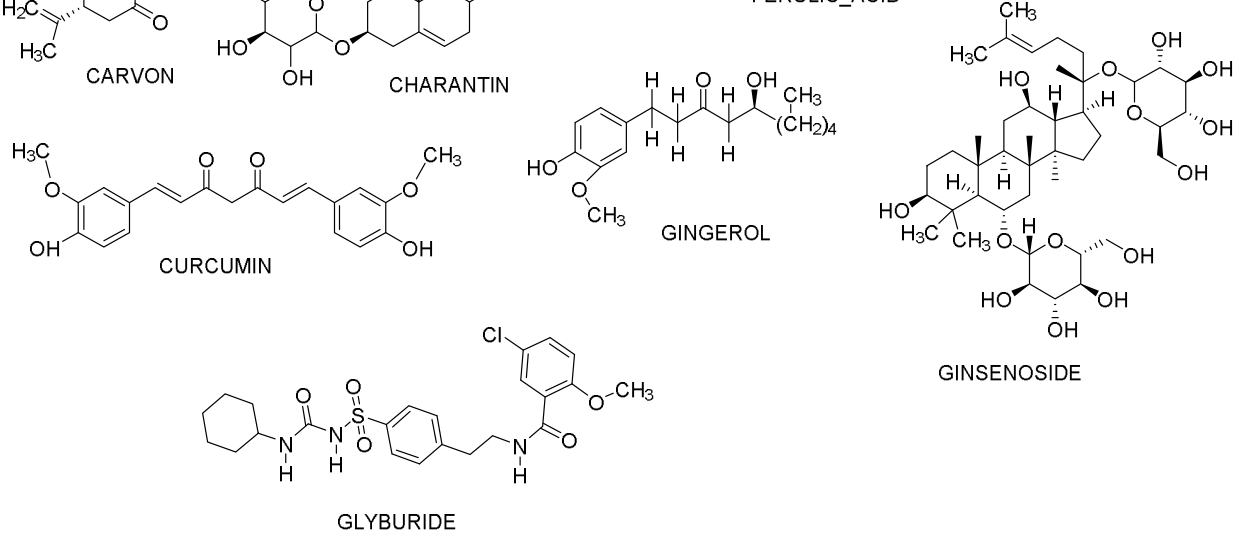




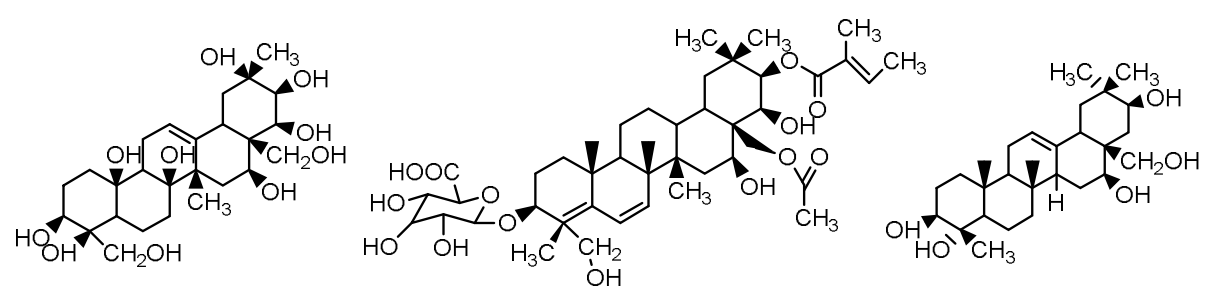

GYMNEMAGENIN

GYMNEMIC_ACID

GYMNESTROGENIN

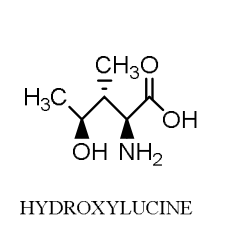

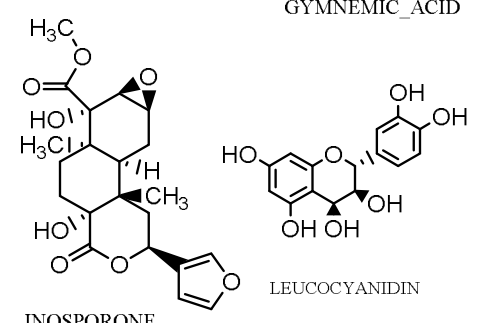

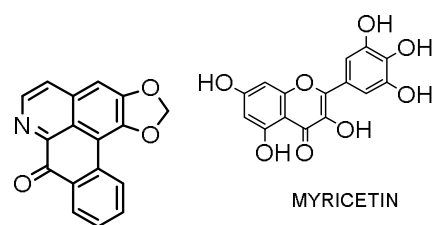

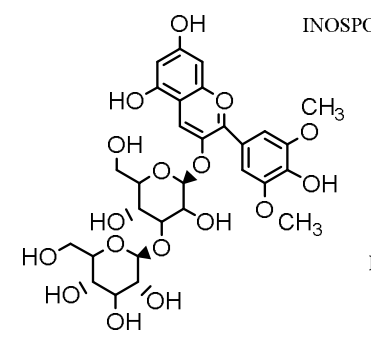<smiles>Cc1cccc(C(=O)/C=C/c2cccc(O)c2)c1</smiles>

METHYL_HYDROXY_CHALCOLI

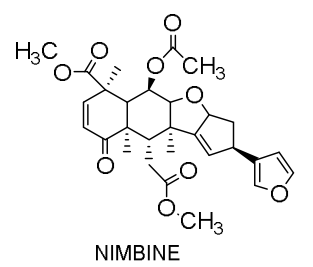

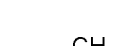

LIRIODENIN<smiles>Cc1ccc(C(C)C)cc1</smiles>

MALVIDIN_LAMINARIBIOSIDE<smiles>COc1ccc(CC(Cc2ccc(OC)c(OC)c2)Cc2c(OC)cc(CC(Cc3ccc(OC)c(OC)c3)OC)cc2OC)cc1OC</smiles>

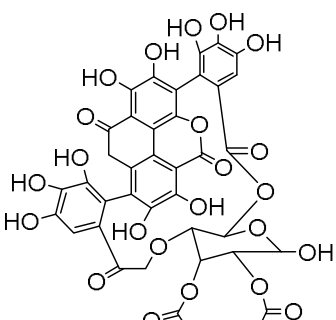

PHELLANEDRENE

O_METHYLTYLOPHORINIDINE<smiles>N=C(N)NC(=N)N</smiles>

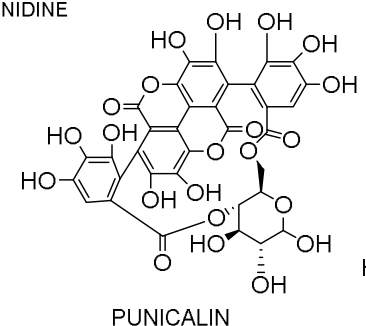

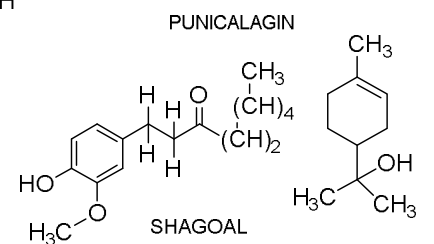

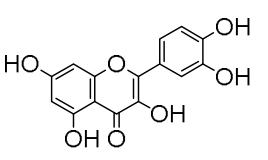

QUERCETIN

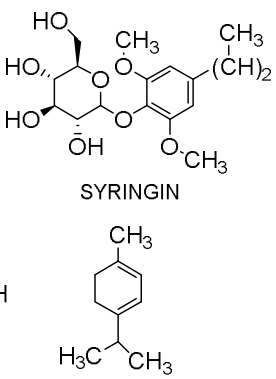
TERPENE

METFORMIN

PUNICALIN $\mathrm{H}_{3} \mathrm{C}^{-} \mathrm{O}$ SHAGOAL

TERPENEOL

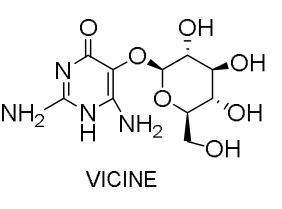

Fig 9. Chemical Structures of Phytoconstituents 


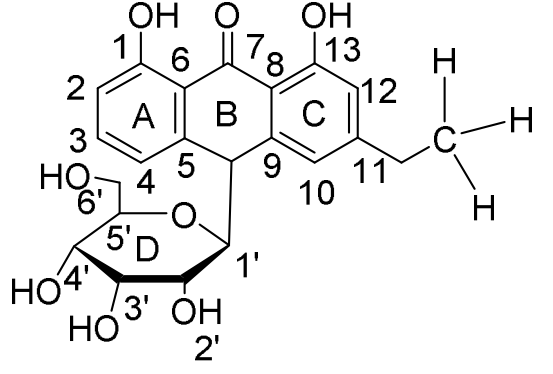

Fig. 10 Structure of ALO

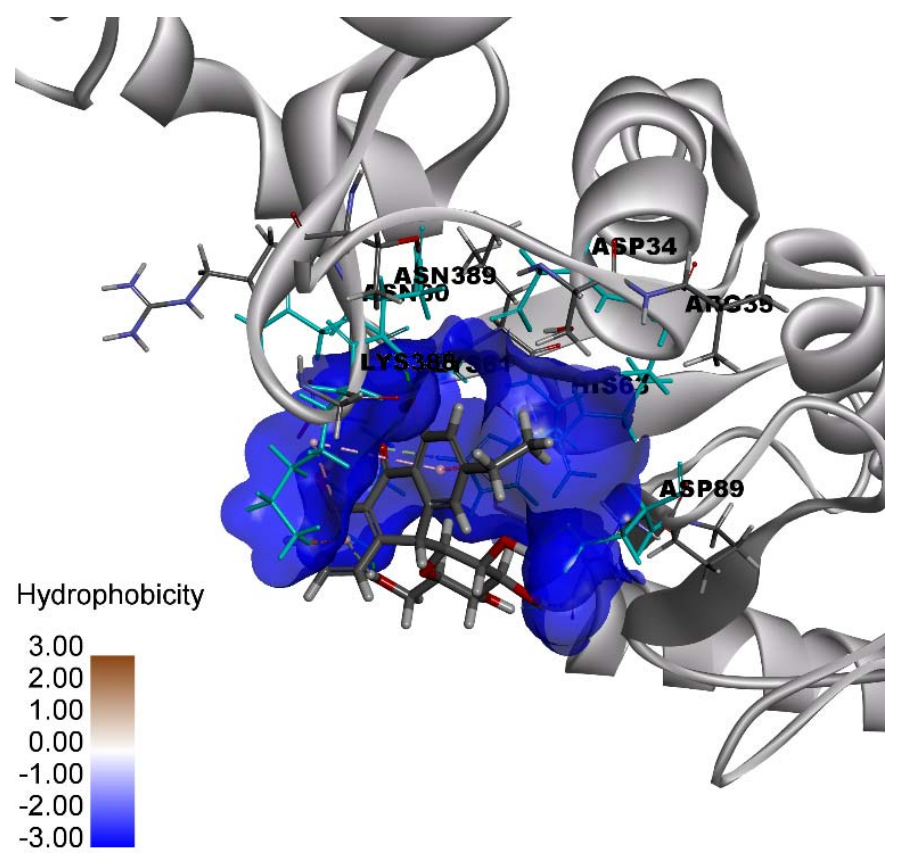

Fig.12 3D Binding of ALO with 3FN1

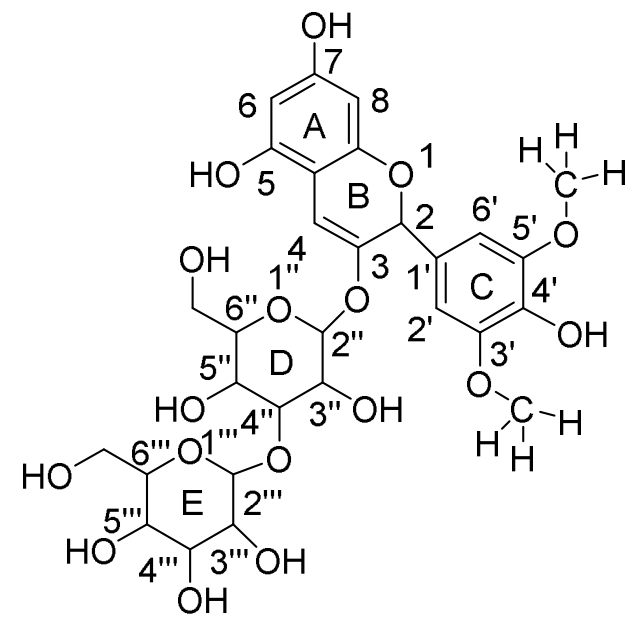

Fig. 11 Structure of MAL

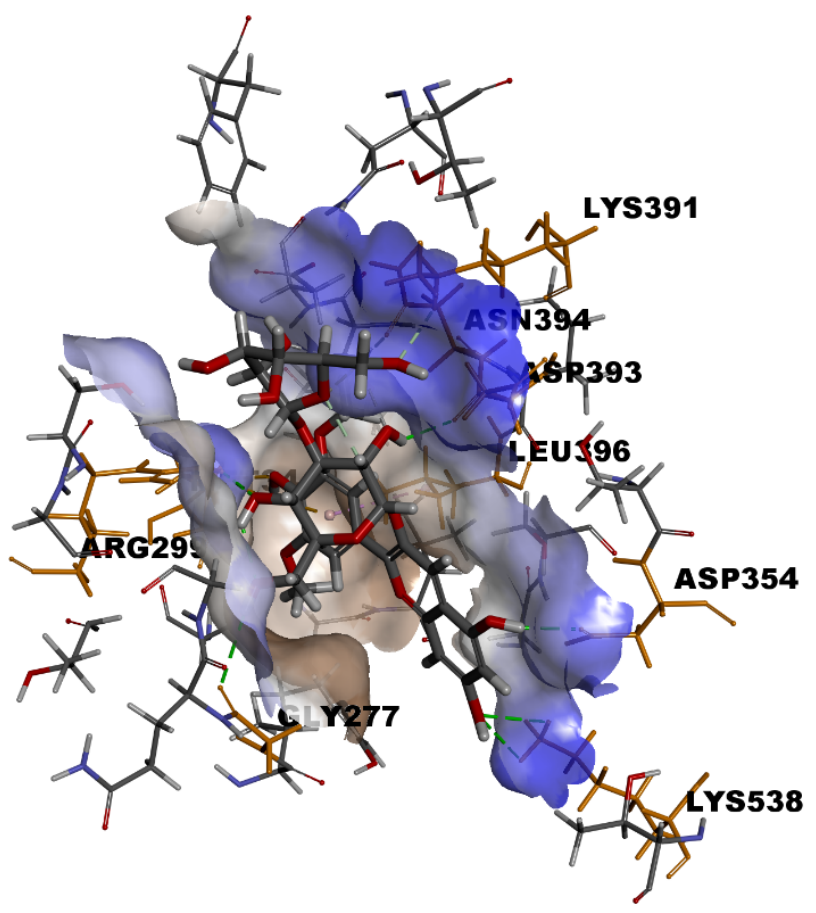

Fig. 13 3D Binding of MAL with 3Q4Z 

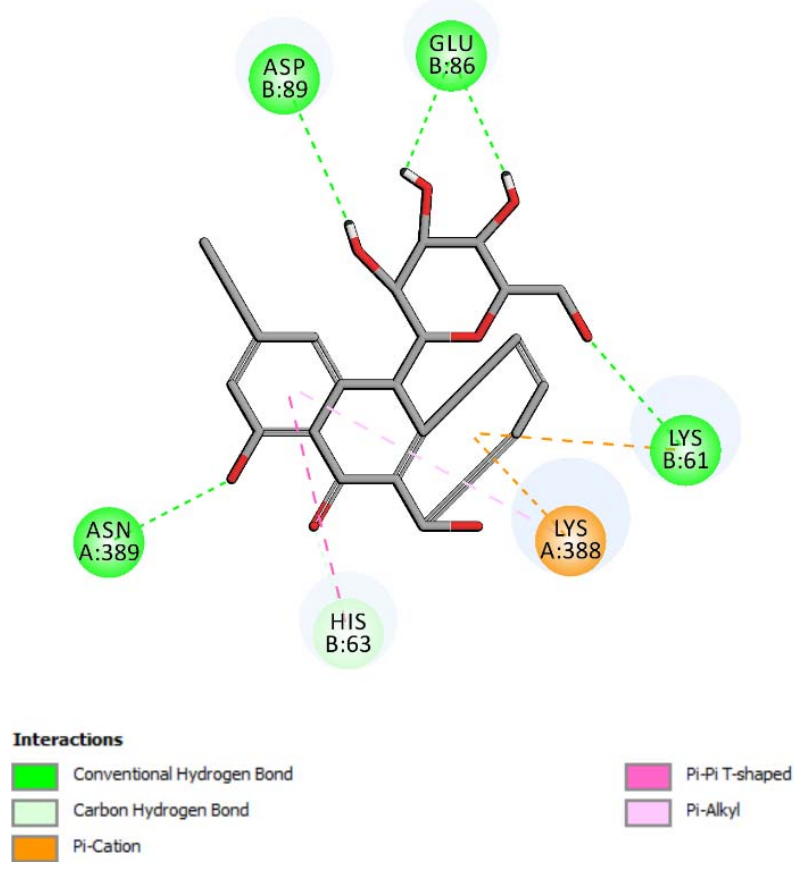

Fig. 14 2D Binding of ALO with 3FN1

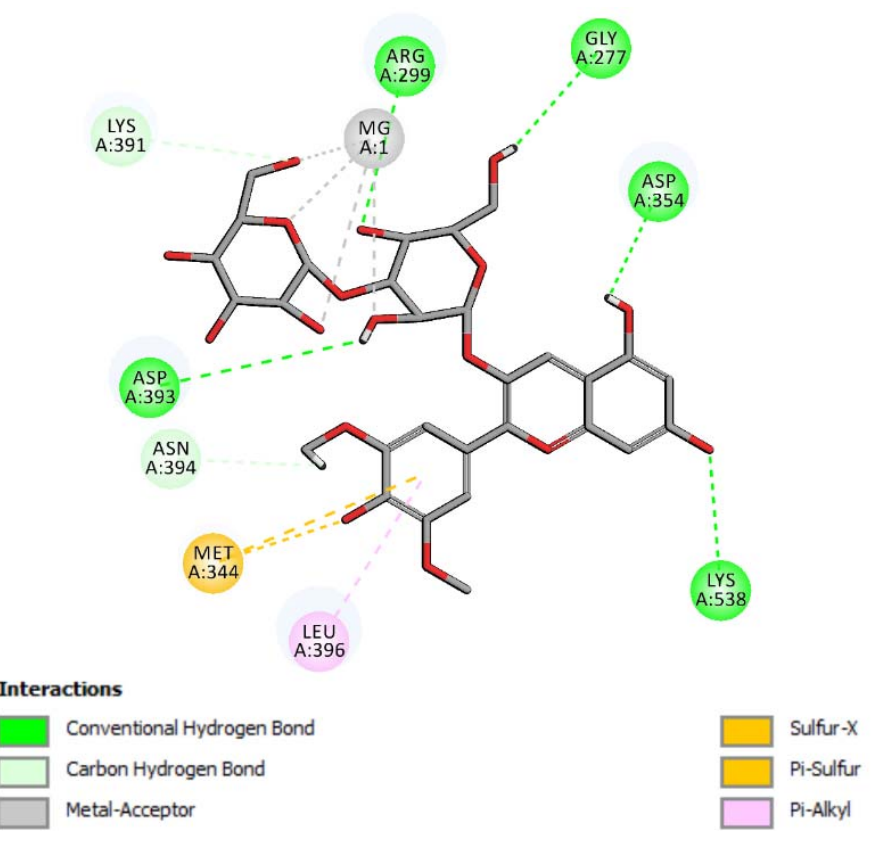

Fig. 15 2D Binding of MAL with 3Q4Z 